HENRIK EMILSSON

PAPER PLANES: LABOUR MIGRATION, INTEGRATION POLICY AND THE STATE
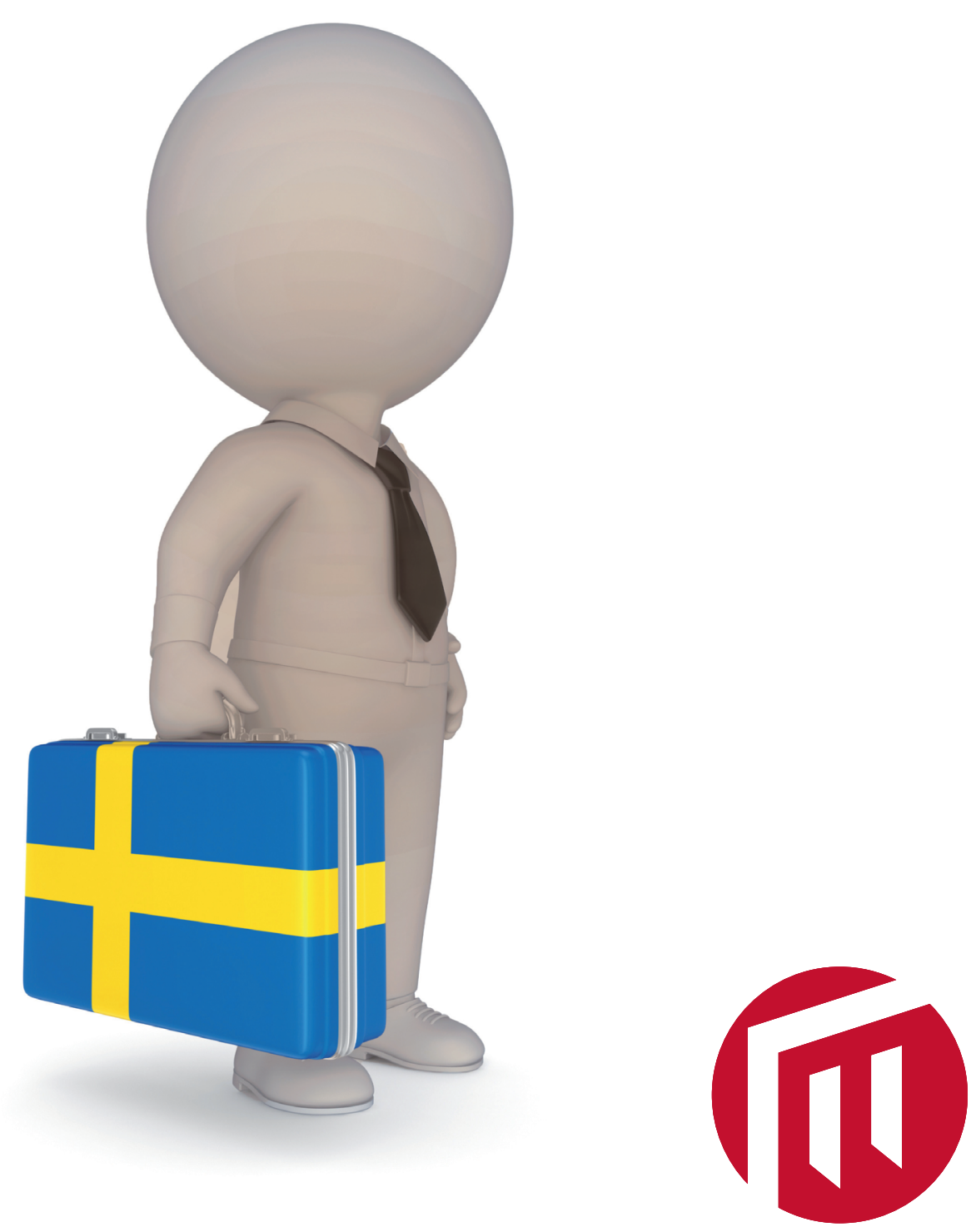

PAPER PLANES:

LABOUR MIGRATION, INTEGRATION POLICY AND THE STATE 
Doctoral dissertation in International Migration and Ethnic Relations Dissertation series: Migration, Urbanisation and Societal Change Faculty: Culture and Society

Department: Global Political Studies, Malmö University

Information about time and place of public defence, and electronic version of the dissertation:

http://hdl.handle.net/2043/2I I 57

(C) Henrik Emilsson, 2016

Printed by Holmbergs AB, Malmö 2016

Supported by grants from The National Dissertation Council and The Doctoral Foundation.

ISBN 978-9I-7I04-730-4 (print)

ISBN 978-9I-7IO4-73 I-I (pdf) 


\section{HENRIK EMILSSON}

PAPER PLANES:

LABOUR MIGRATION, INTEGRATION POLICY AND THE STATE 



\section{Acknowledgements}

The four articles in this dissertation were written in connection with two projects I was involved in. The first, UniteEurope, financed by the EU-7 framework programme, developed a tool to analyse local integration policies. The second, financed by the Swedish Integration Fund, studied the effects of the Swedish 2008 law on labour migration.

There are too many persons to thank, therefore I am keeping the list as short as possible:

My supervisors Pieter Bevelander and Christian Fernandez.

All co-workers at MIM.

All PhDs on the MUSA programme.

All members of the UniteEurope project, and especially Bernhard Krieger, Peter Scholten and Rianne Dekker, who are the co-authors of one of the articles.

Greg Bucken-Knapp for comments at the $90 \%$ seminar.

Jonas Hinnfors for being discussant at the Licentiate disputation.

Anders Hellström and Patrik Hall for reading and commenting on earlier drafts.

Guiseppe Sciortino for his valuable advice. 



\section{CONTENTS}

1. INTRODUCTION............................................... 9

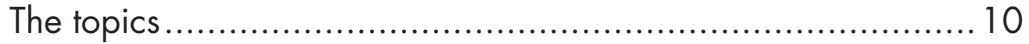

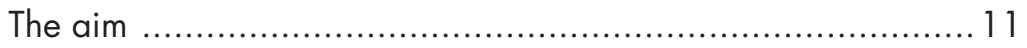

Migration, integration and the state .................................. 12

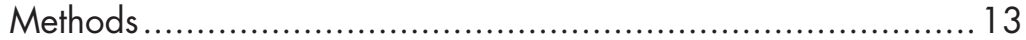

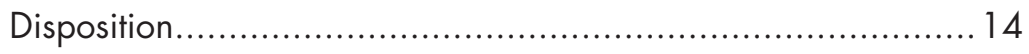

2. MIGRATION AND INTEGRATION POLICY IN SWEDEN... 16

Major developments in Sweden's migration policy.................. 17

The immigrant population of Sweden ................................... 21

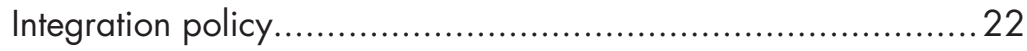

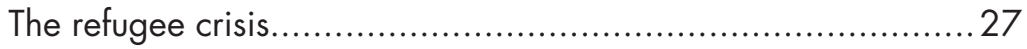

3. LABOUR MIGRATION AND THE STATE .................... 31

The study of migration policies ............................................... 31

Migration policy output: explaining migration policies......... 32

Migration policy outcomes: the state in migration theory.......39

The development of labour migration policies ....................... 43

From demand- and supply-driven models to hybrid models.... 44

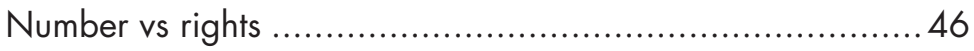

The effects and effectiveness of the 2008 labour migration policy

The Swedish labour migration model: a comparative perspective

The policy outcomes of the 2008 labour migration policy.... 49

Explaining the results..... 
4. INTEGRATION POLICY AND THE STATE ................... 56

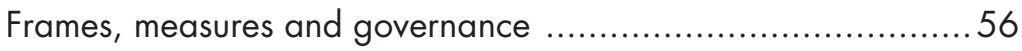

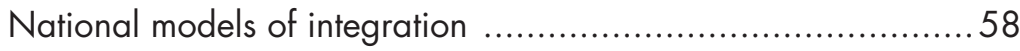

The "local turn" versus the "civic turn" in integration policy........59

The local turn ...........................................................59

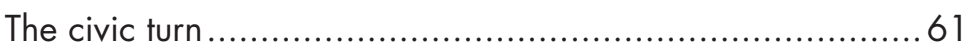

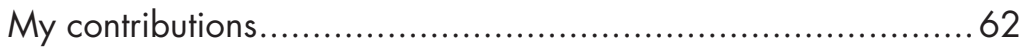

Policy frames or policy measures ..................................64 64

The centralisation of integration policies and the civic turn ....66

REFERENCES ............................................... 67

PAPERS I - IV............................................... 81 


\section{INTRODUCTION}

Globalisation has made the world smaller by allowing people around the world to interact faster and at lower cost than before. Today, more people than ever have access to information about other countries, and different lifestyles and economic opportunities across borders. As methods of travel have developed, distance is less a barrier than it was previously. However, while distances are small, the barriers raised by governments are large (Massey et al., 2002:14). Although international migrants worldwide have continued to grow rapidly over the past fifteen years, reaching 244 million in 2015 - up from 222 million in 2010, 191 million in 2005 and 173 million in 2000 (United Nations, 2016) - they still only account for 3.3 per cent of the world population. Global surveys show that considerably more persons want to migrate. A large poll conducted in 2010 showed that roughly 630 million of the world's adults desire to move to another country permanently, but less than one tenth of them - about 48 million adults - are planning to make the move in the next year (Esipova et al., 2011).

The topic of migration and integration policies is currently at the top of the agenda in Europe. The Syrian and other conflicts have led to a demand for protection in Europe unparalleled since the Second World War. The crisis has shown the tensions between humanitarian principles and states' perceived self-interest, tensions that the EU and its member states have thus far failed to solve. It is clear that many asylum-seekers are also looking out for their own best interests and want to choose their country of asylum, thereby creating a flow of people through Europe towards the northwest - a flow only stopped by fences and border controls at the EU border and between EU countries. 
What the crisis has shown is that the state, and state policies, still play a fundamental role in shaping migration flows. Policy shapes the context within which potential migrants decide whether or not to move, where to go, and for how long (Goldin et al., 2012:116). Take Sweden as an example. Its favourable economic situation, generous asylum policy and absence of any integration requirements for family migration, permanent residence permit or citizenship attracted 12 per cent of the asylum-seekers and 30 per cent of all unaccompanied minors in the EU during 2015 (Eurostat, 2016). When the government decided to introduce border controls on 24 November 2015, the number of asylum-seekers immediately dropped by 90 per cent compared to the months before. Now, Sweden is left with the challenge of facilitating integration for the record number of persons who will be granted international protection.

\section{The topics}

The study of the politics of migration is about the themes of control, security and incorporation (Hollifield \& Wong, 2015). This dissertation revolves around the first and third themes, about the role of the state in controlling migration and facilitating integration. The thesis consists of four peer-reviewed articles that are published in academic journals. Articles 1 and 2 are about the multi-level governance of integration polices. Articles 3 and 4 study the effects of the 2008 Swedish labour migration policy change. Both my articles on labour migration, and the introduction to the thesis, are about non-EU labour migration. Thus, they do not touch upon the free movement of labour within the EU or other areas of free movement.

At first glance, the topics of the articles are very different. Two are about labour migration and two are about the multi-level governance of integration policy. In hindsight a common theme emerges - the role of the state in shaping migration and governing integration policy. In addition, all four articles relate to policy which situates this dissertation in the broad field of migration policy studies. Another common theme in all four articles is the Swedish context. Some of the articles are comparative studies involving other countries, but the Swedish context is still a red line throughout the dissertation. The articles are: 
1. Dekker, R., Emilsson, H., Krieger, B. \& Scholten, P. (2015) A local dimension of integration policies? A comparative study of Berlin, Malmö, and Rotterdam, International Migration Review, 49(3), pp. 633-658.

2. Emilsson, H. (2015) A national turn of local integration policy: multi-level governance dynamics in Denmark and Sweden, Comparative Migration Studies, 3(7), pp. 1-16.

3. Emilsson, H. (2014) Who gets in and why: the Swedish experience with demand driven labour migration - some preliminary results, Nordic Journal of Migration Research, 4(3), pp. 134-143.

4. Emilsson, H. (2016) Recruitment to occupations with a surplus of workers: the unexpected outcomes of Swedish demand-driven labour migration policy, International Migration, 54(2), pp. $5-17$.

The four articles in the thesis do not deal with the current refugee crisis as they were written before the major inflow of migrants. The policy changes in Sweden that followed alter neither the articles' relevance nor their findings or results. So far, the labour migration policy has not been changed; the integration policy changes that have been made (a stronger centralisation and state influence over local political levels) are in line with the findings in the articles. The one major policy change that has been decided concerns asylum and family migration, where a new law adapting all policies to EU minimum levels will take effect in July 2016 (see section headed The refugee crisis).

\section{The aim}

The aim of this thesis introduction to the articles is twofold. First, I would like to give a broader overview of academic discussions related to the two topics: labour migration and migrant integration. Since the role of the state is central in all four articles, the topic of the role of the state in managing migration and facilitating integration is the common theme throughout the introduction, regardless of the topic. Second, I want to highlight the articles' contributions to current academic debates. 


\section{Migration, integration and the state}

The role of the state is a much-debated topic, both in migration and integration policy research. In migration research there are two conflicting trends related to the state as a unit of analysis. On the one hand, the strong criticism of "methodological nationalism" (Wimmer \& Glick Schiller, 2002, 2003) has questioned the relevance of the state as a unit of analysis. At the same time, other researchers have tried to overcome and remedy the absence of the state as a factor in general migration theories (Hollifield, 2008).

The critique of methodological nationalism can be summarised in two main parts. The first critique is the use of the state as an analytical level. It suggests that we should look beyond the state level in our analysis of migration. The second critique is that social science has failed to separate the concepts of the nation, the state and society. By failing to look beyond the state and make these distinctions, methodological nationalism has distorted research on migration in the social sciences and led to descriptive and explanatory inadequacy (Sager, 2016). "Going beyond methodological nationalism requires analytical tools and concepts not colored by the self-evidence of a world ordered into nation-states", Wimmer and Glick Schiller write in their conclusions (2003:599). While I agree that the state should in no way be the only unit of analysis, ignoring the state and the power it has over people would be a mistake. It is quite clear that migrants are deeply affected by state migration policies, regulating the entry to the territory, the rights after settlement and the possibility of taking up citizenship.

I argue that neither of my articles can be accused of methodological nationalism. First, I make a distinction between the state as an arena for policymaking and the state as an actor. In society there are voters, political parties and organised interests all competing to transfer their policy preferences into state policy. However, when policies are decided by the parliament, the state is an actor implementing and enforcing state policies. Second, I see the state as one of several factors that influence migration. A central part of the critique originating from the concept of methodological nationalism is that the nation state is assumed to completely control geographical space. I do not make this claim. However, the policies of states can influence migration flows. I also want to make it clear that the focus in the thesis is migration and integration policies. Many other policy areas, 
such as labour-market and economic policies, influence migration flows and migrant integration. Third, in my study of integration policy, I use a multi-level governance perspective. In my articles, the role and importance of the state is an open question. However, the result points to a centralisation of integration policies where the state level has increased its power over local government levels.

Based on the results of my four articles, I argue that the relevance of the state as a unit of analysis is still strong and impossible to ignore if one wants to understand the patterns of migration and the conditions which migrant newcomers face in their countries of residence. As my articles show, when the Swedish labour migration policy was changed, and the veto of the unions and the state (the Employment Service) was abolished, it enabled social networks and market forces to play out more freely, which led to an increase in labour migration. The Swedish 2008 labour migration policy was designed to solve labour shortages. However, the effect of the new law was mainly the creation of new opportunities for migrants to get work permits and visas to Sweden in order to apply for asylum or work in lowskilled jobs in sectors without labour shortages. Thus, state policies do matter, even if not always in the way in which policymakers intend them to. The state has also tightened its grip on local integration policies in both Denmark and Sweden, despite very different overall policies. Where Denmark's civic integration policies have formed a tighter relationship between the state and the individual, the Swedish way has been to centralise and standardise integration services and reduce local policy autonomy.

\section{Methods}

Different methods and empirical data have been used in the four articles and will not be discussed in detail in the introduction. The articles include both case studies and comparative studies, and statistical data, policy documents and interviews are used as empirical data. For a description of the methods and the empirical material, I therefore refer to the individual articles. Methodological considerations will be touched upon throughout the text, for example when discussing the role of the state in migration policy studies and migration theory, and the study of the multi-level governance of integration. 


\section{Disposition}

The text above has introduced the main topic of this thesis: the role of the state in managing migration and facilitating integration. The remainder of this disposition outlines the content of the introduction to the thesis, the purpose of the chapters and the main arguments.

Chapter 2 describes and discusses migration and integration policy in Sweden. The chapter can be read separately by anyone who is interested in the development of Swedish migration and integration policies, and the current challenges to the Swedish migration regime caused by the "refugee crisis". The text also provides a deeper contextual background to the four articles, which all, in some way, deal with Sweden.

Chapter 3 discusses the role of the state in migration policy, specifically labour migration policy. I start by giving an overview of the academic literature on migration policy and the state. Here, I particularly want to stress the importance of making an analytical distinction between the study of policymaking (policy output) and the study of the effects of policies (policy outcomes). Even though policymaking is not the main feature in my articles, I take the opportunity here to expand upon the subject. I describe the main theoretical frameworks that are used to explain (labour) migration policymaking. Most theories of labour migration policymaking take departure from a political economic framework, emphasising the importance of interest groups and political-economic structures. I make a point of also taking ideas and ideology into consideration for understanding policy choices. After reviewing theories about migration policymaking, I turn to the other side of the coin of migration policy studies; the effects and effectiveness of (labour) migration policies, i.e. policy outcomes. These topics are very much related to the broad field of migration theory - about how state policies influence migration patterns. I spend the rest of the chapter discussing my main topic: labour migration. I describe the general trends in labour migration management. The review shows that the traditional models of labour-migration selection have largely been abandoned, and that most countries now utilise a combination of supply- and demand-driven criteria. In addition, labour migration programmes are increasingly differential and selective where migration categories are given different rights. This overview is an important backdrop 
for understanding the characteristics of the 2008 Swedish labour migration policy, a policy that goes against most international policy developments. After pointing out the particularities of this 2008 policy, I highlight the contributions provided in my articles. Here I show that the effectiveness of the 2008 labour migration policy is low. The abolishment of the labour market test and the introduction of a market-led demand-driven policy has contributed to more lowskilled labour migration and a worse labour market position for the migrant workers. The chapter ends with a discussion of the results and how we can understand these effects.

Chapter 4 changes the topic to integration policy and, more specifically, to its multi-level governance. Even though the relationship between central and local government is at the centre of my analysis in all the articles, these latter also tap into discussions of national models of integration and civic integration policies. My findings contradict previous studies that found a local turn of integration polices. Furthermore, the national turn of integration policies found in Denmark and Sweden cannot be explained by the "civic turn" of integration policies since no such policy is present in Sweden. 


\section{MIGRATION AND INTEGRATION POLICY IN SWEDEN}

Since Sweden is an important context in all four articles of the dissertation, I want to provide a comprehensive background to the country's migration and integration regime. The text is based on an earlier chapter on Sweden which I wrote for the book European Immigration: A Sourcebook (Emilsson, 2014). The chapter ends with some reflections on the recent refugee crisis and its consequences for future policy developments in Sweden.

Sweden is often seen as an exceptional case when it comes to migration and integration policy. In comparison with the rest of Europe, Sweden accepts many refugees, actively encourages new labour migrants, and was one of the very few EU member states to immediately open its doors to citizens from the EU accession countries of 2004 and 2007. In a European context, Sweden may be an exception to the general trend of more restrictive migration policies and assimilation ideals (Borevi, 2012). Although some scholars believe that this exceptionalism might be coming to an end, they still describe Sweden as a country that has aimed to merge openness towards migration and extended rights of citizenship with a political framework free from essentialist conceptions of national belonging (Schierup \& Ålund, 2011). There has also been a strong consensus amongst the political parties on the general direction of migration and integration policies from the late 1960s to today (Borevi, 2012; Ring, 1995). This makes the Swedish case particularly interesting. 


\section{Major developments in Sweden's migration policy}

After the Second World War, Sweden had an open immigration policy, where migrants could travel to Sweden and look for work. Immigrant workers, especially from Finland, Greece, Turkey and Yugoslavia, were attracted to the country to fill vacancies in the expanding labour market. This lasted until 1967, when immigration became regulated for all aliens with the exception of Nordic citizens. The system of regulated immigration meant that the trade unions had the final word on who should be given a work permit. After the economy slowed down in the late 1960s, there was an increased call, especially on behalf of the unions, to stop labour immigration altogether (Lundh \& Ohlsson, 1999). In 1972, after strong opposition from the Workers' Union, the possibility of coming to Sweden as a labour migrant was severely restricted - until the country joined the EU. During the 1980s, the number of asylum-seekers from Eastern Europe and nonEuropean parts of the world rose from about 5,000 at the beginning of the decade to around 30,000 per year between 1988 and 1991. In 1989 parliament adopted new immigration legislation which made it more difficult for asylum-seekers to get a residence permit (Geddes, 2003). However, the legislation had little effect on the number of asylum-seekers, which peaked at 84,000 in 1992 during the civil war in the former Yugoslavia. To relieve the Immigration Board's accommodation centres, law 1994:137 on the reception of asylumseekers was introduced, which meant that asylum-seekers were given financial support if they found their own accommodation during the asylum process. Quickly it became clear that the possibility of securing their own accommodation was more attractive than anticipated; since the reform, about 50 per cent of asylum-seekers have stayed in their own accommodation. This meant not only that cities had to manage an increasing number of asylum-seekers but also that, after immigrants were granted a residence permit, they, too, had the right to stay in the municipality where they had lived as asylum-seekers. This arrangement meant that municipalities had little control over the inflow of humanitarian migrants, and many voiced their dissatisfaction and pointed out the problems both for the asylum-seekers and for the host municipalities (Bevelander et al., 2008). In March 2005, the housing allowance was rescinded in an attempt to reduce the number of asylum-seekers who chose their own accommodation, but without results. 
Current migration legislation is governed by the Aliens Act (Statute 2005:716), which took effect on 31 March 2006. A main objective of the reform was to increase transparency in the asylum process. The biggest change was the possibility to appeal against decisions taken by the Swedish Migration Board in alien and citizenship cases in the migration courts and, as a final and precedent-setting resort, in the Migration Court of Appeal. The system of courts has led to a situation where the ability to immigrate to Sweden is often more determined by case law than by decisions made by the parliament or the government. The Swedish migration system and asylum procedures are also regulated by the Reception of Asylum Seekers and Others Act (Statute 1994:137) and the Reception of Asylum Seekers and Others Ordinance (Statute 1994:361). The government's objective when it comes to migration policy is to:

Guarantee a migration policy that is sustainable in the long term and safeguards the right of asylum and, within the framework of regulated immigration, facilitates cross-border mobility, promotes needs-based labour immigration, makes use and takes account of the impact of migration on development and deepens European and international cooperation (Ministry of Justice, 2011)

Unlike many other countries in Europe, Sweden's migration policy has not become more restrictive during the 2000s and, in general, the seven established political parties have been reluctant to exploit antiimmigrant sentiments (Green-Pedersen \& Krogstrup, 2008; Odmalm, 2011; Ring, 1995). They have united in a show of repugnance towards the anti-immigrant party Sweden Democrats (Hellström et al., 2012). In order to block the influence of the Sweden Democrats after the 2010 election, the centre-right minority government and the Green Party established a Framework Agreement to safeguard the Swedish migration model (Swedish Government, 2011).

The current Swedish position on humanitarian migration is enforced by the implementation of the Council Directive 2004/83/EC on minimum standards for asylum qualification (Bill 2009/10:31). Sweden went beyond the minimum level of protection by introducing a third category for asylum qualification, not covered by the directive. 
In addition to those coming to Sweden on their own to seek asylum, protection is offered each year in the form of the resettlement of people who have sought refuge in a third country and do not have access to any other long-term solution (refugee quota). In 2010, the Swedish refugee quota totalled 1,900 people. Over the past few years, the government has lobbied for the establishment of a Common European Asylum System, strongly supporting the harmonisation of national asylum systems so that all member states offer equal protection, thereby safeguarding the right for migrants to seek asylum while relieving the pressure on the Swedish asylum system.

Since 15 December 2008, Sweden has adopted new rules to facilitate the recruitment of labour from third countries. Given the absence of skill requirements, salary thresholds and limits on the number of permits issued and their renewability, the OECD deems that Sweden appears to have the most open labour migration system of all OECD countries (OECD, 2011). The almost entirely demanddriven system means that employers may recruit workers from abroad for any occupation, as long as they nominally advertise the job beforehand and guarantee respect for wages and conditions in prevailing collective contracts. Labour migrants may also, from the outset, bring their spouses, who are also given free access to the labour market. The new law on labour migration has been criticised by some as a form of guestworker system (Schierup \& Ålund, 2011). Guestworker system or not, it is obvious that the ambition to develop a more flexible labour migration system has had some negative sideeffects. The OECD has noted that labour migrants are entering into low-skilled occupations while only about 50 per cent of recruitment is for occupations on the labour shortage list that is produced twice a year by the Employment Service. This should, according to the OECD, be cause for concern since there is no obvious reason why there should be an increase over time in recruitment for low-skilled non-shortage occupations. The government and the Migration Board seem to be aware of the weaknesses in the labour migration system and, as a result, some new rules and procedures have been passed to combat the trafficking of persons in the labour market and reduce fake contracts and abuse (Migration Board, 2011).

Student migration has long been encouraged by the fact that Swedish universities have not demanded fees from either domestic or 
foreign students. In late 2009, however, the government announced that students from abroad (excluding the EU, the EEA and Switzerland) will have to pay for university studies in Sweden from the winter semester 2011 onwards, arguing that higher education institutions act on a global scale and Swedish universities and colleges should compete on equal terms with universities and colleges in other countries where tuition fees are standard.

The provisions governing the right to migrate to Sweden on family grounds have not undergone any major changes in recent years, apart from the fact that, on 15 April 2010, Sweden introduced a financial support requirement in the Aliens Act as a condition for family reunification. According to the act, the sponsor must have sufficient income to support him or herself and cover his or her own housing costs. The exemptions to this ruling are many. The maintenance requirement does not apply, for example, if the sponsor has been granted a residence permit as a refugee or if a person has lived in Sweden for four years or longer. Nor is the maintenance requirement applicable if the applicant is a child and the person with whom the child claims to have personal ties is the child's parent. This exemption also applies if the child's other parent applies for a residence permit together with the child. It is also possible to grant full or partial exemption from the maintenance requirement if special grounds exist. The financial support requirement thus only covers a small number of persons. For other members of the migrant's family, they can still migrate to Sweden without any financial or other restrictions. Of the 42,000 applications for family reunification in 2011, approximately 200 persons were refused on the grounds that the support requirement was not met (Migration Board, 2012).

Irregular migration has received much attention in the last couple of years. On the one hand, the government has attempted to increase the number of returns of failed asylum-seekers, and to strengthen the administration allocations of the Swedish Migration Board and the National Police Board (Migration Board, 2011). As a way to avoid forced returns, voluntary returns are encouraged by grants of up 9,000 for a family. On the other hand, irregular migrants have been given extended social rights, like access to subsidised health care and the right for children to go to school. There has been a reluctance to implement regularisation programmes though compromises have 
been made, as, for instance, between 15 November 2005 and 31 March 2006. A total of 31,000 cases were examined according to the interim legislation and around 17,000 residence permits were granted (Migration Board, 2007).

\section{The immigrant population of Sweden}

Immigration has long been greater than emigration in Sweden, which means that the foreign-born population continues to increase.

At the beginning of the millennium, foreign-born people represented 11 per cent of the population. By the end of 2015 this figure had reached 17 per cent, or almost 1.7 million persons. ${ }^{1}$ Almost half of the foreign-born population comes from a European country and one third from an Asian country. The most common country of birth is Finland ( 9 per cent of foreign-born persons) followed by Iraq ( 8 per cent), Syria ( 6 per cent) and Poland ( 5 per cent). While the groups born in Finland, Yugoslavia and Norway are slowly decreasing, other groups are growing rapidly. In 2000, the number of persons born in Iraq was 49,000, growing to 73,000 in 2005 and 132,000 in 2015.

Despite substantial immigration, the number of foreign nationals remained steady at between 400,000 and 500,000 during the period from 1980 to 2006 due to high naturalisation rates. These rates can be explained by the absence of economic or language requirements to become a Swedish citizen and, since 2001, it has been possible to hold dual citizenship. There was a change in this trend in 2005, when the number of both EU and third-country nationals increased mainly because they do not yet meet the requirements for length of stay to become a Swedish citizen. In 2015, there were 780,000 foreign citizens living in Sweden.

Since 2006, immigration has been at an all-time high. In general, all types of immigration increased throughout the 2000s. Sweden is one of the main EU countries of destination for asylum-seekers, and more and more of those who come to Europe choose Sweden as their destination country (UNHCR, 2012). The humanitarian crises in Iraq, Somalia and Syria led many people from these countries and regions to seek asylum in Sweden. A significant share of the humanitarian migrants has been unaccompanied minors. In 2004 and 2005 , close to 400 unaccompanied minors applied for asylum

1 All statistics are from the Statistics Sweden website: http://www.scb.se. 
in Sweden and, by 2011, their number had increased to 2,650. The majority were, as in previous years, boys aged 15 to 17 years, primarily from Afghanistan, Somalia and Iraq. Family migrants are the largest immigrant category, and their number also increased during the 2000s as a direct consequence both of families reuniting with persons granted asylum and to a general increase in family formation, where Swedish citizens marry a person from abroad.

The increase in recent years of the number of people coming from outside the EU to Sweden to work is due to the country's new policy on labour migration. However the openness of the Swedish system has not led to a massive increase in labour immigration to Sweden. Most labour migrants are berry-pickers from Thailand and IT professionals from India and China. Immigration from EU/EES also increased during the last decade, especially from the 10 countries that joined the EU in 2004. The only immigrant category that has experienced a decrease in recent years is that of foreign students after the introduction of tuition fees.

\section{Integration policy}

The first coherent immigrant policy in Sweden was decided by parliament in 1975 (Bill 1975:26). It had three goals: equality, freedom of choice and partnership. The equality goal implied that migrants should have the same living standards as the native population. Therefore, migrants with residence permits were equipped with (almost) the same rights as Swedish citizens and were included in the welfare state. The goal of freedom of choice meant that migrants themselves were free to decide if they wanted to retain and develop their cultural identity or assimilate into Swedish society. The goal of partnership implied that immigrant groups and the majority population should work together. The policy was clearly multicultural, as immigrant groups were expected to form new national minorities (Soininen, 1999). To fulfil these goals, several policies were introduced: mother-tongue instruction in schools for migrant children, voting rights for foreign citizens in local elections and subsidies to immigrant associations. Even before 1975, however, immigrants received the same social benefits as Swedes. With few exceptions, there was no formal exclusion of immigrants from the major institutions of Swedish society. This strategy was in line with the swift acceptance that migration was of a permanent nature. 
Instead of introducing a guestworker system, the aim was to usher the immigrants as swiftly as possible from denizens to citizens (Geddes, 2003).

The 1986 immigrant policy (Bill 1985/86:98) was a first step away from a multiculturalist policy. The reasons were both economic and cultural (Geddes, 2003; Schierup \& Ålund, 2011; Södergran, 2000). There was a slowing down of economic growth and a growing realisation that the economic assimilation of migrants had failed. In the cultural realm, immigrant groups, the bill said, should no longer be seen as ethnic minorities with constitutional entitlements. The concept "minority" should be reserved for groups with a very long history of living in Sweden (such as the native Sami and Tornedal Finns of northern Sweden). Another subject discussed was the freedom-of-choice goal, a much-discussed topic at the time (Borevi, 2002). Now it was emphasised that there were limits to the choice and that all have to adapt to common basic laws and norms. As a consequence, the 'immigrant and minority policy' was renamed 'immigrant policy'. After the 1980s reorientation, the state remained the guarantor of the social and political rights of immigrants but no longer of their minority cultural rights.

As the number of humanitarian migrants gradually increased, responsibility for integration was transferred from the Labour Market Board to the Immigration Board and the municipalities. This shift of responsibility was part of a larger reform aimed at decentralising integration to the municipalities.

The new approach was further institutionalised by Bill 1997/98:16 Sweden, the Future and Diversity: From Immigrant Policy to Integration Policy, which increased the emphasis on individual rights and equality. The earlier policy was considered to have overly accentuated cultural differences between Swedes and immigrants, thereby gradually reinforcing mental and social boundaries between 'us' (the Swedes) and 'them' (the immigrants). The new approach aimed at streamlining immigrant integration measures in all policy areas. Both immigrants and the majority population would have to change and adapt to a society characterised by diversity and shared democratic values. A new authority, the Swedish Integration Board, was created to support the municipalities in their efforts to develop introduction programmes for humanitarian migrants, promoting integration and monitoring the integration policy objectives. This 
new approach marked the end of the previous multiculturalist approach and was a clear move towards individual diversity and socio-economic integration. The new integration policy objectives were:

1) equal rights, responsibilities and opportunities for all, regardless of ethnic or cultural background;

2) a community based on diversity; and

3) a society characterised by mutual respect and tolerance, in which everyone can take an active and responsible part, irrespective of background.

Fifteen years after the introduction the integration policy, it is still in place even if the second and third objectives were removed in the 2008/2009 budget.

According to Wiesbrock (2011), integration policies in Sweden have, in comparison to measures applied in other Western European countries, four main characteristics:

- participation is voluntary;

- the content of the programme is employment-oriented;

- until recently the programme was highly decentralised, with its implementation largely taking place at the level of the municipalities; and

- naturalisation is seen as an important element, rather than the ultimate goal, of the integration process.

Immigrants in Sweden have the right to receive free instruction in the Swedish language but are not obliged to participate. As a direct consequence of the voluntary nature of integration measures, a failure to participate or pass the language course does not have any residential or financial consequences. Sweden does not require immigrants to take an integration test in order to be granted access to permanent residence rights. Passing the language test is not a prerequisite for access to long-term resident status or citizenship. Revocation of the residence permit is thus not available as a mechanism to sanction non-compliance. Yet, newly arriving immigrants may be compelled for financial reasons to participate. 
Although Sweden developed an immigrant policy early on, the first anti-discrimination law did not come about until 1986, when the Act against discrimination (Bill 1985/86:98) and an Ombudsman for Ethnic Discrimination were established. The Act condemned ethnic discrimination but did not make it a criminal offence. The Ombudsman for Ethnic Discrimination (DO) was charged with the role of providing advice in individual cases of discrimination, shaping public opinion and assessing the need for future measures against ethnic discrimination. The 1986 law was replaced by the new 1994 law, which dealt solely with ethnic discrimination in the labour market. According to Graham and Soininen (1998), the law offered weak protection as it allowed ethnic discrimination to take place up to the point where its consequences became too obvious. In 1999, a more comprehensive legislation prohibiting direct and indirect ethnic discrimination was introduced.

The late development of an anti-discrimination law can be explained by the Swedish corporatist model (Graham \& Soininen, 1998; Schierup \& Ålund, 2011). It was assumed that the general welfare policy and the accord between unions and employers functioned as guarantees for equality. There was a reluctance to interfere in the traditional role of the partners who had the chief responsibility for solving the problem of ethnic discrimination in the labour market. The matter was defined primarily as a question for the organisational rather than the legislative side of the political system. In the late 1990s and early 2000s, there was a growing concern that discrimination was one of the main reasons behind poor labour market integration. Theories about structural and institutional discrimination became popular amongst social scientists and spread to civil servants in state administrations. In the spring of 2004 , a government commission was set up on 'power, integration and structural discrimination' which was mandated to identify structural discrimination on the grounds of ethnic or religious affiliation, identify and analyse the underlying mechanisms and their impact on power relations, and propose measures to combat such structural discrimination to increase opportunities for influence and power for those at greatest risk. The commission submitted its final report to the Ministry of Justice on 17 August 2006. By this time, the theories had gone out of fashion and, when the centre-right coalition replaced the Social 
Democratic Party after the 2006 elections, the commission was no longer wanted. Instead, the new government sought to introduce a new discrimination law. On 1 January 2009 the Discrimination Act (Swedish Code of Statutes 2008:567) entered into force. At the same time a new agency, the Equality Ombudsman, was established to supervise compliance with the Act. The law replaced seven different laws, covering different discrimination grounds, merging them into one single legislation. A new penalty and compensation for discrimination was also introduced for infringements of the Discrimination Act.

Swedish citizenship is available for immigrants after five years' residence if they are of full legal age and have not committed a criminal act. ${ }^{2}$ There are no requirements of economic, cultural or linguistic assimilation. Since July 2001, Swedish citizenship law fully permits dual citizenship, whereas earlier legislation demanded that Swedish nationals, with some exceptions, should only have one citizenship. The 2001 law passed without much controversy or public debate (Howard, 2009). The idea behind the change was that globalisation, increasing international mobility, multiple national bonds and multiculturalism demanded a more flexible notion of citizenship. They also implied a strong focus on the experiences, desires and identities of individual migrants (Gustafson, 2002).

Comparative research suggests that Sweden is the country where equal rights are the most fully realised. ${ }^{3}$ At the same time, the socioeconomic integration of migrants is not a success. The employment rate for native-born Swedes has been over or very close to 80 per cent throughout the 2000s, compared to about 65 per cent for those born abroad. The situation in the labour market is especially difficult for non-EU immigrants (Bevelander \& Dahlstedt, 2012) and persons granted international protection (Luik et al., 2016). The school results are also troubling. For example, less than 60 per cent of the pupils from Africa and Asia are eligible for upper-secondary education, compared to over 90 per cent for pupils born in Sweden (Ministry of Employment, 2011). The most recent attempt to speed up labour market integration is Bill 2009/10:60 which entered

\footnotetext{
2 Nordic citizens can apply for Swedish citizenship after two years in Sweden and stateless persons or recognised refugees can apply after four years.

3 According to the Migrant Integration Policy Index (MIPEX). Available online at http://www.mipex.eu/
} 
into force on 1 December 2010. The reform means that the state, through the Swedish Employment Service, has taken over from the municipalities the responsibility for coordinating introduction efforts for humanitarian migrants. Besides the introduction reform, most integration measures are focused on strengthening economic incentives; for migrants to improve their skills and for employers to hire them. To strengthen competitiveness in the labour market, newly arrived migrants have access to subsidised employment.

\section{The refugee crisis}

The refugee crisis did hit Sweden disproportionally. In 2015, over 162,877 persons applied for asylum in Sweden, ${ }^{4}$ comprising 12.4 per cent of all asylum applications in the European Union, and more than six times greater than the EU average per capita (Eurostat, 2016). These record numbers were not solely due to Syrian asylumseekers, who represented a little less than one third of applicants. Over a quarter were Afghani citizens, more than half of whom were unaccompanied minors. In total, over 35,000 unaccompanied minors applied for asylum in Sweden in 2015 - more than a third of the total number of minors arriving in the European Union.

The political response was slow and hesitant. The Swedish strategy was to find solutions at EU level. When this strategy failed, drastic measures were introduced. On 12 November, the government decided to introduce internal border controls, ${ }^{5}$ which only served to create large temporary camps in Malmö where asylum-seekers had to wait for accommodation in other parts of the country - but it did not significantly reduce flows to Sweden. On 24 November, even more drastic measures were implemented when the government decided to introduce external border controls. ${ }^{6}$ Now, no one without an identification card was able to cross from Denmark to Sweden. Combined, these measures reduced the number of asylum applicants to about 3,000 per month during the first quarter of 2016 .

4 Official statistics from the Migration Board, "Statistics", http://www.migrationsverket.se/OmMigrationsverket/Statistik.html.

5 Swedish Government, "Regeringen beslutar att tillfälligt återinföra gränskontroll vid inre gräns", (news release, November 12, 2015), http://www.regeringen.se/artiklar/2015/11/regeringen-beslutar-atttillfalligt-aterinfora-granskontroll-vid-inre-grans/.

6 Swedish Government, "Regeringen föreslår åtgärder för att skapa andrum för svenskt flyktingmottagande", (news release, November 24, 2015), http://www.regeringen.se/artiklar/2015/11/ regeringen-foreslar-atgarder-for-att-skapa-andrum-for-svenskt-flyktingmottagande/. 
The surge in numbers has affected capacity in a number of ways. First of all, the average processing time from application to decision in asylum cases went from as short as three months (before the crisis) to nine months at the beginning of 2016. The Migration Board (2016) expects it to increase to 12 months before the trend turns. Second, the asylum reception system itself has come under severe strain. Currently, over 173,000 persons are enrolled in the Migration Board's asylum reception system, ${ }^{7}$ 92,000 of whom have been assigned accommodation by the Migration Board, and 49,000 of whom have found accommodation themselves. The municipalities are responsible for housing 32,500 unaccompanied minors. There are also capacity problems for those granted protection - in April 2016, there were about 13,000 such persons still waiting at reception centres for somewhere to live. ${ }^{8}$ Third, the housing situation is alarming (National Board of Housing, Building and Planning, 2015). Asylum-seekers who choose to arrange their accommodation on their own almost always live with relatives or friends and create overcrowding in already socio-economically and ethnically segregated neighbourhoods. After obtaining a residence permit, many continue to stay in precarious housing conditions which make it difficult for newcomers to fully engage in the introduction programme.

After settlement in a municipality, all persons have the right to an introduction programme organised by the Employment Service. When the new programme was introduced in December 2010 it planned for about 16,500 participants (Bill 2009/10:60). The forecast has not held. The number of participants has grown steadily and reached over 55,000 in February 2016. The Employment Service estimates that there will be close to 80,000 participants in 2017 , growing to over 100,000 in 2018-2020 (Employment Service, 2016).

The main political focus has been to adapt the migration policy with the clear intention of reducing the number of asylum-seekers. Such a large reception of asylum-seekers in a short time burdens the system and, according to the government, poses a serious threat to public order and internal security. Two strategies are used: to limit access to Swedish territory and to reduce the attractiveness of Sweden

7 Official statistics from the Migration Board, "Statistics", http://www.migrationsverket.se/OmMigrationsverket/Statistik.html.

8 Official statistics from the Migration Board, "Statistics", http://www.migrationsverket.se/OmMigrationsverket/Statistik.html. 
for asylum-seekers. The border controls of 24 November tried to close off access to the Swedish territory and thereby hinder persons applying for asylum. In addition, parliament approved a temporary migration law with the intention of making Sweden a less attractive choice for asylum seekers (Bill 2015/16:174).

The proposed migration law is limited to three years and adjusts most of the Swedish asylum and family migration laws to the minimum level under EU law and international conventions. This means that Sweden is, for the first time, granting only temporary residence permits to all persons given asylum (with the exception of resettled refugees). The transition to a permanent residence permit is granted to migrants who can prove that they can support themselves once the temporary permit has expired. Family migration is also being restricted. Only persons with refugee status according to the Geneva Convention will have the right to family reunification, and the income requirement for family formation is increased and extended to most groups. ${ }^{9}$ The new migration law is thus a huge step away from the previous Swedish policy position. However, some migration and integration policies are still more liberal than in other comparable countries. There are still no civic integration requirements, such as language skills or civic tests, for permanent residence. The citizenship legislation remains the same, which means that there are still no income requirements and knowledge or language tests for becoming a Swede. In addition, all persons granted temporary residence permits are given the same rights to welfare as other residents.

On a parallel track to trying to reduce the number of asylumseekers reaching Sweden, the government has also taken measures to increase the capacity of the asylum reception and settlement system for new arrivals and to settle persons granted international protection, by introducing a law that makes it mandatory for municipalities to accept a designated number of migrant newcomers (Bill 2015/16:54). The law is controversial because it is at odds with the principle of local self-government enshrined in the constitution. The reason for the reform is the lack of capacity in the current system, which is based on the immigrants' own ability to find housing in combination

9 Read more about the new policy in English: Swedish Government "Proposal to temporarily restrict the possibility of being granted a residence permit in Sweden", (news release, April 8, 2015), http:// www.government.se/press-releases/2016/04/proposal-to-temporarily-restrict-the-possibility-of-beinggranted-a-residence-permit-in-sweden/. 
with voluntary agreements for municipalities to accommodate those who need help. The Act imposes an obligation on a municipality to settle newly arrived immigrants staying at the Migration Board's reception centres. The Act does not, however, affect the possibility for newly arrived immigrants to find a place on their own. The exact distribution is determined yearly by a government ordinance, and is based in part on recommendations from the County Administrative Boards. ${ }^{10}$ How the law will be enforced is not entirely clear, as there are no sanctions involved.

The long-term consequences of the refugee crisis on migration and integration policies is still unclear. So far, all policy measures are marketed as temporary solutions to an acute situation.

10 The 2016 ordinance "Förordning (2016:40) om fördelning av anvisningar till kommuner" can be found here: http://www.riksdagen.se/sv/dokument-lagar/dokument/svensk-forfattningssamling/ forordning-201640-om-fordelning-av-anvisningar_sfs-2016-40. 


\section{LABOUR MIGRATION AND THE STATE}

\section{The study of migration policies}

The traditional way to understand the state according to the realist school in International Relations is that states are sovereign actors that are driven by self-interest (Donnelly, 2005). Power over movement in and out of a state, and what rights non-citizens are given, are two of the foundations of sovereignty (Balch, 2016). At the centre of self-interest are survival/security concerns and economic interests. From what we know, migration cannot fully be understood from this narrow realist perspective. If states are sovereign actors only acting out of self-interest, why then do liberal states accept unwanted migration (Joppke, 1998)? Many researchers have tried to understand and explain why some states are willing to accept rather high levels of immigration when it would seem not to be in their interest to do so and when public opinion is hostile. Since the 1970s, European countries have tried to reassert control over migration flows in response to hostile public opinion (Hollifield \& Wong, 2015). Yet, immigration has persisted, leading to a growing gap between the goals of immigration policies and the outcomes of these policies - an argument known as the control gap hypothesis (Cornelius \& Tsuda, 2004). However, a gap between stated goals and outcomes does not tell us much about why and how such a gap has come about, even less when one considers the gap between public opinion and migration outcomes. When studying migration policies and their effects on migration it is therefore essential to differentiate between the study of policymaking (policy outputs) and the study of 
the effects of policy (policy outcomes) (Czaika \& de Haas, 2013). The study of policy output investigates countries' will and attempts to regulate flows and stocks. The main focus of this research is to understand both how and why countries chose specific migration policies and the role of the state and state policies in influencing actual migration flows. The study of policy outputs is about the results of the policies. Thus, in the study of migration policies there are two dependent variables: immigration policy outputs and immigration policy outcomes. The distinction between policy outputs and policy outcomes is an important focus of my two articles about labour migration (Emilsson, 2014, 2016) as they mainly deal with policy outcomes. In order to give an overview of the field of migration policy studies I will discuss the issue of migration policymaking before turning to my main area of interest: how migration policies affect migration flows. In the general introduction to the subject, the broad field of migration policies is discussed, but with an emphasis on labour migration.

\section{Migration policy output: explaining migration policies}

There are many different theories, conceptual frameworks and perspectives through which to understand migration policymaking. In his book, The Politics of Immigration, James Hampshire (2013) provides an overview of factors which he believes influence migration policy. Here, democratic politics is seen as the main source of demands for closure and immigration restrictions. He identifies the role of political economy and constitutionalism as the main explanations for the politics of openness. I will follow Hampshire's structure to briefly discuss the main ideas and theories used to explain migration policymaking. ${ }^{11}$

\section{Public opinion and party politics}

According to Hampshire (2013), in democracies, popular attitudes and party competition generate substantial pressure for governments to act toughly on immigration. In most democracies, voter preferences are channelled through political parties who, in turn, are supposed

11 Howard (2009) takes a similar overview of factors influencing openness (demographics, Interest groups, international norms and courts) and restrictions (public opinion). However, he uses different terms compared to Hampshire, and includes demographics as an additional factor of pressure for openness. 
to deliver policy outcomes that match the preferences of the voters. Already in 1957, Downs (1957, p.28) wrote that "parties formulate policies in order to win elections, rather than win elections in order to formulate policies". A more recent version of the same idea, the "mandate thesis", understands political parties as organisations that link voter preferences with political outcomes (Klingemann et al., 1994). Political parties compete in a political marketplace, and governments deliver public policies in exchange for political support (i.e. votes). Even taking into account the multidimensionality of voter preferences, one would expect that, according to this model, public policies would fall in line with voter preferences, especially median voter preferences. When it comes to migration policymaking there is ample evidence that this model is too simplistic (Akkerman, 2015; Facchini \& Mayda, 2008; Hix \& Noury, 2007). Afonso (2014) points to three elements that complicate the relations between the voters, parties and policy output. First, vote-seeking concerns are not the only driver of political parties' policy positions. Parties seek to balance vote-seeking strategies with other considerations influenced by existing policies and socio-economic conditions. Second, much of the literature on immigration policy positions has ignored interest groups, which nevertheless do play an important role in the elaboration of party policies. Parties often depend on groups for funding, resources and expertise, and they seek to balance these relationships with vote-seeking strategies. Third, there is a substantial difference between what parties say and what parties do. This calls for a better integration of electoral politics and policymaking processes in the analysis of migration policies. Odmalm (2011) also notes that party competition tends to play out differently for immigration issues compared to other policy areas, diffusing the correlation between the median voter position and policy output.

The puzzle is therefore to understand why mainstream opposition to immigration has not translated into greater restrictions on immigration. Thus, there seems to be important filters between popular attitudes to immigration and actual migration policies. Hampshire's (2013) two main explanations pushing the politics of openness are the role of political economy and constitutionalism. 


\section{Political economy}

In political economy explanations, the main focus is often the role of interest groups in the policymaking process. For example, Sciortino (2000) identifies four main frameworks through which to explain migration policy: the pluralist model, the class-based model, the realist model and the neo-corporatist model. ${ }^{12}$ What these four have in common is that they depart from an aggregation of interests either interest groups, class interests or state interests. In these four frameworks, democratic politics is largely absent.

Most theories of labour migration policymaking depart from a political-economic framework, where interest groups are seen to compete in the policymaking process to further their economic interests (Cerna, 2016; Freeman, 1995). Freeman (1995) was one of the first researchers to discuss organised interests and their influence on migration policy output. In his model, every policy regulation distributes costs and benefits for various groups and creates winners and losers in the policymaking process. These costs and benefits can be either concentrated or diffuse. From this factor-cost logic, Freeman deduces what position powerful interest groups, such as labour unions, agricultural and business lobbies, are likely to take in debates on immigration.

Different cost-benefit distributions create specific "modes of politics": interest group, clientilist, entrepreneurial or majoritarian (Freeman, 2005). ${ }^{13}$ Freeman (1995) argues that the typical mode of immigration politics in liberal democracies is client politics in which policymakers interact intensively, and typically out of public view, with groups having a direct interest in immigration. Client politics develops, according to the model, because the benefits of immigration

12 The pluralist model views policies as the result of a process whereby a plurality of actors, from entrepreneurs to churches, from trade unions to ethnic associations, try to secure specific benefits for their category, without paying attention to the systemic quality of the whole. Class-based models view policies as balancing the need for an industrial reserve army with the need to avoid social unrest and high levels of conflict between native and foreign workers. Realist models see the state as a specific organisation, endowed with endogenous interests, internal and international, that policymakers and state bureaucracies pursue on their own. Neo-corporatist models focus on the way in which states manage the pressures deriving from transnational and international constraints with the structure of interests internal to the receiving society.

13 In a later publication, Freeman adds a fifth mode that he calls "populist" (Freeman, 1998). Populism shares characteristics with Wilson's entrepreneurial mode, including high levels of conflict and a penchant for restrictionism, and with interest group politics to the extent that opponents of immigration gain additional voice. Successful populist entrepreneurs may in this case succeed in institutionalising competition between pro- and anti-immigration groups, leading to the emergence of a more stable interest group mode. 
tend to be concentrated while its costs are diffuse. This gives those who expect to gain from migration stronger incentives to organize than those who anticipate bearing its costs. Freeman has most famously used this model to predict and explain the development of labour migration policies. On the one hand, powerful business interests lobby for open labour migration policies in order to lower wages. On the other, fewer powerful interests are mobilising against immigration.

Some researchers and critics of Freeman's argument have noted that the theory is American in nature and works less well in a European context. Balch (2010) suggests that the dynamics are different in parliamentary democracies where parliamentarians are more susceptible to the anti-immigration wishes of the voters. Balch (2010:35) also argues that one weakness in the approach is that it tends to construct a causal linkage between changes in policy and the successful intervention of the business and other interest groups specific to that area. The focus of interest groups has also been criticised for neglecting the role of legal and institutional factors (Boswell, 2007) and ideological variations. As Hollifield and Wong (2015:239) say: "by focusing so exclusively on process, we lose sight of the importance of institutional and ideological variations within and among states". An interest group approach also has difficulty explaining cross-national differences in policy outputs, because similar kinds of actors in different countries tend to advocate different policies (Bleich, 2002). Freeman (1998) himself acknowledges that one of the shortcomings of his model is being too dependent of generalisations about labour, landowners and capitalists' economic interests.

Another widely used political-economy framework explicitly used to explain labour migration policymaking is inspired by the idea of Varieties of Capitalism (VoC) (Hall \& Soskice, 2001). This framework is, like Freeman's, focusing on lobbying and material interests. It is considerable more detailed than Freeman's idea of material interests as it also predicts and explains the type of labour migration policy which employer organisations should want.

According to Devitt (2011), different socio-economic regimes (consisting of welfare, education and training policies, and labour market institutions) shape the supply of domestic labour which, in 
turn, conditions the nature of employer demand for labour migration. Menz (2011) and Cerna (2009) also emphasise the influence of employer associations and unions in shaping governments' labour migration policies. In opposition to Freeman, Menz argues that employers do not always lobby for more liberal policies, but rather for migrants with certain skill profiles which correspond with the predominant production strategy (Menz, 2011). Liberal market economies reinforce employer preferences for market-based policies focused on addressing their own skills needs rather than sectorspecific skills. This means that employers will support policies allowing the entry of low-skilled and high-skilled immigrants and those with transferable skills. On the other hand, in coordinated market economies, firms encourage states to develop sector-wide training frameworks for meeting their workforce needs and to pursue high-wage, high-skill production strategies. These arrangements potentially create a demand for high-skilled but not low-skilled immigrants. Caviedes (2010) also suggests that production regimes shape employer preferences. However, in contrast to Menz, Caviedes argues that these regimes are influenced more by sector-specific norms rather than by national regulatory systems. Employers in service sectors characterised by market-based forms of coordination and weak levels of unionisation and employer collaboration have greater demand for flexible labour supplies. Service-sector employers thus tend to be more vocal in advocating for liberal labour immigration policies. This suggests that states with large service sectors will be subject to greater pressure from employers for expansive work visa reforms in order to meet their flexibility requirements (Caviedes, 2010). What all VoC theories have in common is their focus on the central role of employer preferences in translating labour market demands generated by production regimes into government policy. These dynamics are supposed to be especially relevant for explaining policy outcomes in states with corporatist policy traditions, where the social partners have an embedded role in both the industrial relations system and public policymaking architecture (Wright, 2015).

\section{Liberal norms}

The idea of liberal norms, what Hampshire (2013) calls constitutionalism, as a driver for migration policy openness is central 
in migration policy research. Liberal norms are an important factor because they function as constraints on migration policymaking. There are different views about where liberal norms that push for expansive migration policies originate. According to the theory of the international human rights regime, states have lost sovereignty to supranational organisations and, as a result, have also lost some or most of their ability to control migration flows (see, for example, Sassen, 1998; Soysal, 1994). Firstly, the transformation in the organisation of the international state system and the emergence of transnational political structures have complicated nation-state sovereignty and jurisdiction. Secondly, the emergence of universalistic rules and conceptions regarding the rights of the individual, formalised in international codes and laws, oblige nation states to not make distinctions on the grounds of nationality when granting civil, social and political rights. The first argument implies that there are limits to the kind of migration policy a country can have (policy output) where the limits are set by international conventions, while the other argument has more to do with policy outcomes - that countries have granted rights to non-nationals which, in turn, attract migrants. Thus, according to the theory of the international human rights regime, the limits to migration policymaking are both the formal standards set in international conventions and the internalised norms of human rights coming from the conventions and the transnational institutions upholding them.

Other researchers argue that liberal norms originate from domestic forces, supported by constitutionalism. Hollifield $(1992,2004)$ argue, in line with Soysal (1994), that a rights perspective has developed that constrains immigration policies. However, where Soysal traces the origin of these rights to the international level, Hollifield underlines that liberal norms and principles have evolved at the domestic level. According to Hollifield $(1992,2004)$, international migration is a function of economic forces, networks and rights, where the rights are the results of political decisions. Thus, the continuation of migration after many countries tried to close their borders in the early 1970s is not only a result of economic differences and networks, but also the expansion of rights for foreigners in liberal democracies. Rightsbased politics and more expansive citizenship policies have worked to stimulate immigration and weaken the capacity of democratic 
states to control their borders. Under liberal constitutions foreigners have rights, while states are constrained by constitutional norms and procedures. States sometimes leave the decision-making power to determine who can stay and who can not to independent juridical systems that reduce the possibility for direct political involvement (Cornelius \& Tsuda, 2004; Joppke, 1998). This makes it possible for domestic NGOs, advocacy groups and legal practitioners to fight for immigrants' rights through domestic as well as international courts. Both the rights-based liberal state and the rights flowing from international organisations and human rights law are constraining the immigrant policymaking of European democracies. The presence of liberal norms, wherever they originate some argue, makes migration policymaking different to most other policy areas, where the conflicts follow a left-right cleavage.

\section{Neo-institutionalism: the power of ideas and ideology}

Political parties and organised interests groups are not the only "transmission belts" between the state and society (Hall, 1993). Over the past decade or so, a number of scholars have stressed the role of ideas in shaping policymaking, also in the field of international migration and ethnic relations (Balch, 2010; Bleich, 2002; Bonjour, 2011; Boswell, 2007; Buzan, 1993; Lavenex, 2001). As part of the 'neo-institutionalist turn', these scholars explore how different traditions of thought, discourses, paradigms or frames have influenced public debates and political decision-making. This kind of analysis moves beyond the narrower focus of traditional political analysis on the pluralist interplay between interest groups, which largely neglects the role of elites, institutions and ideas. According to Fischer (2003), the question is not whether ideas are important but, rather, how important are they?

This relatively new field in policy studies emphasises the importance of ideas and knowledge in policymaking. At the same time, several competing and/or overlapping schools of thought with different concepts and emphasis have developed. Policy frames (Entman, 1993) and policy paradigms (Hall, 1993) both discuss ideational frameworks that can be applied in any given policy field. The frames and paradigms allow for interpretations of an issue and suggests potential solutions that policymakers can adopt based on consensually accepted beliefs. In his 2003 book, Fischer 
closely examines two ideational frameworks for interpreting policy change; discourse coalitions versus advocacy coalitions. What they have in common is the belief that policy preferences cannot, in a simple way, be inferred from objective, rational interests and that both problems and preferred solutions are constructed by different actors (politicians, the media, academics), drawing on available ideational resources or patterns of thought. Another contribution focuses on policy narratives. For example, Boswell et al. (2011) argue that many contributions focusing on ideas overlook the specific role played by knowledge claims in policymaking. The most ambitious and consistent contribution to bringing this ideational framework to labour migration studies is the book Managing Labour Migration in Europe: Ideas, Knowledge and Policy Change by Balch (2010), in which he claims that, in order to understand contemporary European labour migration policymaking, we should look at ideas, knowledge and expertise rather than at pure interests. "The argument is that we need to pay attention to the battles of ideas and the ways in which ideas and knowledge can recast the split between what is designated as "wanted" and "unwanted" by policy." (Ibid. p.30).

This section has provided an overview of different theories for explaining migration policymaking. What most theories agree on is that public opinion alone cannot explain migration policymaking. If public opinion directly influenced policymaking, then most, if not all, liberal democratic countries would have more restrictive migration policies than they currently have. On the other hand, the factors seen as pushing for openness, interest groups and liberal norms, cannot explain the considerable divergence of policies between similar countries. I do not have the space to expand on the argument here, but I believe one must look closer at ideas and ideologies in order to understand the different migration policy choices that countries do pursue. The peculiar Swedish labour migration policy choices in 2008 (see section The Swedish labour migration model) goes against most established theories, and is hard to explain this without considering ideology.

Migration policy outcomes: the state in migration theory One of the starting points of this thesis is that state policies are an important factor in understanding and explaining migration flows. However, migration theories were, for a long time, not very interested in the role of the state in determining migration movements and 
patterns. Neoclassical macro-economic theories explain migration flows by geographic differences in wages that cause people from lowwage countries to move to high-wage countries (Ritchey, 1976). The wage differential model of migration extends the theory to include measures of the probability of finding employment (Todaro, 1976). Micro-economic theories, sometimes referred to as human capital theory, take their departure from individual rational actors' decisions to migrate if a cost-benefit calculation leads them to expect a positive net return, usually monetary, from movement (Sjaastad, 1962). Stark (1991) has broadened the perspective by emphasising the importance of migration strategies at the household and not the individual level. Structuralists regard the explanations above as reductionist as they neglect macro-scale conditions. The real forces behind migration are, according to their view, found on a structural level and are explained by the development of global capitalism (Piore, 1979; Wallerstein, 1983). More-recent migration theories combine the micro and macro levels and introduce a meso-level that emphasises the importance of networks in moulding and structuring patterns of migration (Faist, 2000). There has also been a call for an inter-disciplinary, multitheoretical, approach along the lines of what Massey et al. (1999), Brettell \& Hollifield (2007) and others have suggested.

What is often missing in even the integrated approaches is the state as a factor in shaping migration patterns (Hollifield, 2008; Massey et al. 1999). Migration is often hindered by rigid regulations and bureaucratic processes. Labour migration from third countries must, for example, be explained by theories and factors other than the free migration regime within the EU. Borders and migration policy regulations must be taken into account when migration patterns, and the fact that relatively few persons migrate despite economic disparities and immigrant networks, are explained (Zolberg 1981, 1989). Or as Hollifield (2004) puts it, market forces and kinship networks are necessary conditions for migration to occur, but the sufficient conditions are legal and political. In the influential book The Age of Migration, Castles \& Miller (2009) acknowledge that states are important but, in their review of theoretical explanations of migration patterns, the state is largely absent (p. 20-49). They acknowledge this shortcoming and write that constraining factors, such as government restrictions, are mainly dealt with as distortions of the rational market in economic theories of migration. As Massey 
et al. (1999) put it, sorting out which of the explanations are useful is an empirical and not only a logical task. For example, if policy changes directly affect immigration, it seems obvious that states can influence migration flows.

The discussion about migration policy outcomes revolves around the role of states in shaping international migration flows. Many migration researchers have claimed that this question has largely been ignored (Zolberg 1999:71); they have therefore made efforts to bring the state back into migration theory (Hollifield \& Wong, 2015). It is true that differentials in wage levels and job availability between countries, migrant social networks, development of a migration industry and the establishment of migration systems all contribute to prompting migrants across borders, regardless of the strategy of nation states. It is therefore difficult to predict the effects of any migration policy or migration policy change. Nevertheless, the state has the final say in who gets to stay and under what conditions.

\section{Studying the effects of migration policy}

Studies of migration policy outcomes have become more frequent in recent times, and two of my articles in the dissertation (Emilsson 2014, 2016) contribute to this body of research by studying the migration policy outcomes of the Swedish 2008 law on labour migration. One of the main weaknesses in the study of policy outcomes has been the lack of comparative policy data. Some progress has been achieved in recent years as several different projects have tried to systematise policy developments in countries in order to be able to account for policy effect on migration. (Bjerre et al., 2015). There are also conceptual and methodological challenges, since one can study migration policy at several different levels. In my articles on migration policy outcomes, I make an important point of distinguishing between policy effects and policy effectiveness. Policy effects refers to the relation between the implemented regulations and measures and the migration outcomes, while policy effectiveness is the relation between migration policies on paper and the migration outcomes. Migration outcomes can be divided into the volume, timing, direction and composition of migration flows (Czaika \& de Haas, 2013). A change in policy for one category of migration often generates unintended effects on other migration flows as well. De Haas (2011) calls this kind of migration outcome substitution effects. 
There are indications that migration policies and laws do matter, both when explaining differences in the volume and composition of immigration between countries and changing migration patterns within a country. Ortega and Peri (2013), for example, have studied the determinants of international migration and the role of migration laws. The data consist of annual bilateral migration flows covering 15 OECD destination countries and 120 sending countries for the period 1980-2006. The overall results show that international migration flows are highly responsive to per capita income at destination. This elasticity is twice as high for intra-European Union (EU) migration, showing different migration dynamics for intra-EU migration and migration from non-EU countries, and indicating the importance of migration policies and border controls. They also find that the tightening of laws regulating immigrant entry rapidly and significantly reduces immigration flows.

Several authors have attempted to explain the number of asylumseekers, over time and across countries, including the role of state policies (Barthel \& Neumayer, 2015; Hatton, 2004, 2011; Neumayer, 2004, 2005; Thielemann, 2004, 2012; Toshkov, 2014). Overall, most econometric studies find that destination country effects matter, particularly the migrant stock and either the change in GDP or the unemployment rate. Most of these studies also find some evidence that more restrictive asylum policies reduce the number of asylum applications. In addition, there are indications that shared language and geographical proximity also have an effect on the number of asylum-seekers. However, since the studies use different independent variables to measure policy strictness, and different empirical data and statistical methods, it is difficult to estimate how big the policy effects are. Nevertheless, there is quite strong evidence that destination country effects matter, for asylum-seekers, too. Economic determinants, migrant networks and migration policies all influence the number of asylum applications.

As research results in the previous section show, the limited effects of policy on the number of asylum-seeker applications to a country are clear, probably partly as a result of internationally binding norms and conventions limiting countries' policy choices. This is not the case for labour migration policies, where countries are freer to pursue whatever policies they like. 
Because states have greater policy discretion when they design labour migration policy, we should be able to predict more distinct policy effects in this area. However, there are fewer studies about the effects of labour migration policies and most of them come from traditional settler countries with a longer tradition of labour migration. Green and Green (1995), for example, found that the introduction of the Canadian points system for labour migration in 1967 had a strong effect on the occupational composition of new immigrants. The 1997 labour migration reform in Australia was found to improve labour integration outcomes and reduce welfare dependency (Hawthorne, 2005).

An article by Czaika and Parsons (2015) examines the degree to which skill-selective migration policies are effective in increasing the inflow and selection of high-skilled labour immigrants. Ten OECD destination countries and 185 origin countries are studied over the period 2000-12, including Sweden. The results show that points-based selection models are much more effective in attracting and selecting high-skilled migrants in comparison with demandled policies that include requiring a job offer, clearance through a labour market test, or working in a shortage-listed occupation. Job offer systems deter both sets of workers, the high-skilled most of all. Labour market tests are shown to increase the share of high-skilled relative to lower-skilled migrants. The imposition of shortage lists, however, significantly reduces the overall selection on skills because they deter high-skilled more than low-skilled migrants. Shortage lists are therefore not effective in attracting highly qualified migrants since the lists often comprise occupations that are not classified as highly skilled. Finally, the availability of permanency rights reduces the overall skill selectivity of immigrant flows.

\section{The development of labour migration policies}

Designing labour migration policies is different from designing family migration policies and, especially, asylum policies. In this policy field, the state is more sovereign since there are fewer international conventions and norms about admission rules and rights for migrant workers. There is an International Convention on the Protection of the Rights of All Migrant Workers and Members of their Families (1 July 2003, No. 39481), but no major labour migration receiving 
countries have signed it. ${ }^{14}$ The European framework for labour migration is also quite week. The introduction of the EU Blue Card for highly skilled non-EU labour migrants (Council Directive 2009/50/EC) is binding for the member states. However, the directive largely respects member states' control over conditions for admission (Caviedes, 2010). Thus, countries can largely design their own labour migration models based on their own perceived self-interests.

The results thus far also confirm the marginal role of the Blue Card. More than 90 per cent of all Blue Cards issued in Europe come from Germany (Expert Council of German Foundations on Integration and Migration, 2015a). Other member states, while having introduced the Blue Card, have continued to prioritise their own recruitment instruments. In addition, it does seem unlikely that a common approach to admissions will be developed any time soon (Geddes \& Niemann, 2015).

\section{From demand- and supply-driven models to hybrid models}

The most common way to categorise labour migration policies is to differentiate between two models for selecting labour migrants: supply-driven and demand-driven (Chaloff \& Lemaître, 2009; Papademitriou \& Sumption, 2011). ${ }^{15}$

In supply-driven models, the state selects the labour migrants with the knowledge and skills that are expected to be needed in the medium and long term. Typically, a points system is designed in which different forms of human capital - such as education level, age, work experience and language skills - are assessed. If a person who wants to immigrate reaches a certain number of points a permit is awarded, usually in the form of a permanent residence permit. Often, the number of immigrants selected is predetermined by a yearly quota. Australia, Canada and New Zealand have all had supplydriven models that use a points system to select the most attractive labour migrants. Potential labour migrants were selected based on their level of education, age, work experience and language skills. The first points system for selecting labour migrants was introduced in Canada in 1976 and was based on human capital theory (Becker, 1993), according to which it is individuals' training and skills that

14 https://treaties.un.org/Pages/ViewDetails.aspx?src=IND\&mtdsg no=IV-13\&chapter=4\&lang=en. 15 For a discussion of the pros and cons of demand- and supply-driven labour migration models, see Hailbronner \& Koslowski (2008). 
determine how productive they will be in the labour market and hence how attractive they are to potential employers. Australia introduced a similar points system in 1989 and, shortly thereafter, in 1991, New Zealand followed.

A demand-driven model is based on employers' immediate demand for labour. Almost all demand-driven models start from specific employers initiating the recruitment process by asking for permission to hire a person from a third country. Most demand-driven labour migration models set up several criteria for granting such a request, a so-called labour market test, which can, for example, examine whether there is available domestic labour, or stipulate that the work requires certain qualifications or provides a certain salary. Labour market tests can also include shortage lists where only some occupations are opened up for recruitment. Usually, a temporary work permit is given which is tied to a specific employer in a specific occupation. With continuous employment, the temporary work permit can then possibly be converted into a permanent residence permit. Sometimes, especially in the European literature on labour migration, demanddriven models are separated into two types - liberal and coordinated (Bucken-Knapp, 2007) - the difference between them being based on who has influence over the work permits: employers (liberal) versus a combination of employers, state representatives and unions (coordinated). In addition, a coordinated labour migration policy usually has a more substantial labour market test. European countries, as well as the United States, have traditionally used demand-driven models (Facchini \& Lodigiani, 2014).

Today, most countries have abandoned strict supply- or demanddriven models and opted for a combination of both - so-called hybrid models (Kolb, 2014; Koslowski, 2014). The supply-driven models in Canada, Australia and New Zealand have been adjusted to take greater account of labour market demand, trying to find the right balance between human capital requirements and employment offers (Desiderio and Hooper, 2016; Hawthorne, 2005, 2011). This way, the models try not only to ensure that labour migrants are highly skilled, but also that their particular skill is valued in the labour market. The latest policy innovation in the points system took place in 2003 when New Zealand introduced a new selection mechanism, a so-called Expression of Interest (EOI) (Bedford \& Spoonley, 2014). Instead of sequentially accepting all applications that meet 
the points requirement, the EOI model adopts a more targeted and active selection process which takes place in two steps. The first step is similar to the standard points system in which the candidate must achieve a certain score to be considered as a potential labour migrant. The difference from a standard points system is that all those who attain the required score are placed in a common pool of candidates, where they remain for a maximum of six months. Every other week, the responsible authority choses a fixed number of candidates with the highest scores. The other candidates in the pool are available for employers to recruit. A practical advantage of the new model is that it avoids the long waiting times that have been a recurring problem in countries with a points system, especially in Canada (Bedford \& Spoonley, 2014). After evaluations proved that the new EOI model was successful in New Zealand, both in terms of waiting times and of the status of immigrants in the labour market (Hawthorne, 2011), Australia introduced a similar model in 2012. In addition, Canada introduced a variant of the EOI model in 2015 - Express Entry (EE) (Desiderio \& Hooper, 2016; Finotelli \& Kolb, 2015).

Many countries in Europe have also developed hybrid models for selecting labour migrants, implying a convergence of labour migration policies between traditional settler countries and European countries (Finotelli \& Kolb, 2015). For example the UK, Austria and Denmark have all introduced variations of the points system, combining demand- and supply-driven selection mechanisms (Expert Council of German Foundations on Integration and Migration, 2015a; OECD, 2013; Somerville, 2013).

\section{Number vs rights}

The hybrid models reflect the increasing complexities of modern national labour markets, which have created a very different kind of labour demand today to that which existed during the 60s and 70s (Menz \& Caviedes, 2010). As a consequence, countries have designed more-selective labour migration policies targeting specific skills (de Haas, Natter and Vezzoli, 2014). What is new about contemporary migration management, Hampshire (2013:57) summarises, is "the extent to which governments seek to regulate the size and composition of labour migration flows through selective and highly differentiated policies and programmes." Regardless of the labour migration model, states selectively try to attract high-skilled migrants 
while restricting low-skilled migrants to temporary labour migration programmes with fewer rights (Dauvergne \& Marsden, 2014; De Somer, 2012; Gsir, 2013; Regine, 2012).

In his highly influential book The Price of Rights (2013), Ruhs studies 104 labour migration programmes in 46 high-income countries and finds a trade-off between openness and rights. This observation highlights an often forgotten aspect of labour migration policies: the conditions and rights given to labour migrants after their acceptance. Ruhs' findings suggest that each receiving country chose a labour immigration policy that maximised the specific country's national interest. The trade-off between numbers and rights represents what Banting (2000) has called the two forms of welfare chauvinism: either a restrictive benefits policy designed to deny resident foreigners access to social benefits under the same conditions as the citizen population, or a restrictive immigration policy designed to prevent foreigners coming into the country and having access to comprehensive social programmes.

In this section, I have described different models for selecting labour migrants. There is a general trend for countries to abandon strict supply- and demand-driven selection models, and to introduce hybrid models in order to maximise economic benefits. This has made labour migration policies more selective, in terms of both admission and rights given to different categories of migrants. The differential labour migration policies have also paved the way for a return of large-scale temporary labour migration.

\section{The effects and effectiveness of the 2008 labour migration policy}

The Swedish labour migration model: a comparative perspective

As both my articles (Emilsson 2014a, 2016) explain in more detail, the 2008 Swedish labour migration law was a clear breach of an almost 40-year-long period of state-controlled labour migration. Even though the old policy was also demand-driven, it was based on state-controlled selection with strict labour market tests. Now it is the employers, not state agencies or unions, who decide the need for labour and the part of the world from which they wish to recruit it. There are no restrictions with regard to skills, occupational 
categories or sectors and there are no quantitative restrictions in the form of quotas. The only condition to obtaining a work permit is an offer of employment with a livable wage and that the level of pay is in line with applicable collective agreements and general insurance conditions. ${ }^{16}$ The basic objective of labour migration policy is meeting labour needs that cannot be met efficiently by domestic labour, while avoiding adverse effects on the labour market for residents (OECD, 2009). This means deciding who and how many to admit, and for which jobs (Chaloff, 2014). By not deciding on any of these aspects, the Swedish model for labour migration goes against almost all international trends by opting for a "pure" demand-driven labour migration policy that OECD (2011) calls one of the world's most open. It defies the trend of balancing the numbers vs rights and the closely related trend towards more selective labour migration policies. $^{17}$

The rules and regulations are described in detail in Emilsson (2014, 2016). However, it is useful to highlight the main differences of the Swedish labour migration model here, since it has direct relevance for later discussions of the effects of the 2008 law, and the possibility of generalising the research findings.

First, the Swedish regulations of entry and rights are the same for all types of labour migration, both high- and low-skilled. Ruhs (2015) has noted that all countries, with the exception of Sweden, use different labour immigration programmes for admitting migrants for employment in low-, medium- and high-skilled jobs. Before 2008, Swedish labour migration policy was separated into five different streams, which also gave the migrants different rights. For example, a high-skilled migrant whose skills were considered to be of longterm use was accorded a permanent residence permit, while other categories of labour migrants received temporary work permits. In the 2008 legislation, all labour migrants should be treated equally and be given a $2+2$ year temporary permit with the possibility of being granted a permanent residence permit after four years.

16 The factual minimum wage is set to 14,300 SEK per month, since it is the level of income above which a single household is not eligible for social allowance.

17 In his famous book, Ruhs (2013:100-102) highlights the "Swedish policy experiment" in a special section. In the report by The Expert Council of German Foundations on Integration and Migration (2015a, p.37), where they review the labour migration policies of Canada, Germany, Austria and Sweden, they conclude that "Sweden differs from the other comparison countries examined in this chapter in almost every aspect of labour migration policy." 
Second, there is no obvious trade-off between the numbers and rights in the Swedish labour migration policy. There are no numerical quotas. At the same time, labour migrants are given quite extensive rights. They can bring family members if their stay is expected to be over six months, all have a clear pathway to permanent residence permits and citizenship, and they are included in the welfare state. The main restriction is that labour migrants must stay with the original employer for the first two years, and in the occupation for an additional two years.

Third, Sweden has a "pure" demand-driven model, and there are no elements from supply-driven ones. There are no considerations related to human capital as it is the employers who are selecting the migrants. Thus, the trend toward hybrid models is not present in the Swedish case. Also, there is no sectoral or occupational focus. The only thing needed to be granted a work permit is to have an offer of employment with a promise of a salary according to the occupational norm. In practice, a labour migrant must earn a sufficient income by Swedish standards so as not to be eligible for a social allowance. Thus, the effective minimum wage is set at SEK 14,300/month (about EUR 1,500). This wage level is below the lowest collective agreement and is only accepted for part-time employment. ${ }^{18}$ Migrants can be hired for any occupation without having any particular skills.

Fourth, the Swedish model mixes labour migration and the asylum system. Asylum-seekers who have been employed during their asylum process can, under certain terms, "change tracks" and become labour migrants.

This peculiar policy design makes it an extra interesting case through which to study the effects of policy change.

\section{The policy outcomes of the 2008 labour migration policy}

Almost eight years after the policy change, we now know a great deal about the effects and effectiveness of the 2008 Swedish labour migration policy. Most research has focused on specific topics, such as the exploitation of workers (Axelsson et al., 2013; Woolfson et al., 2011), or particular labour migration groups, such as berry-

18 Sweden has no legislation on a national minimum wage. This means that, in each individual case, the Swedish Migration Board examines whether the terms offered (i.e. salary, insurance protection and other terms of employment) are in accordance with the conditions applying to all employees in that occupation, conditions established by so-called collective agreements between representatives of a union and employers. 
pickers (Hedberg \& Fuentes-Monti, 2013; Kamoltip Kallstrom, 2011; Wingborg, 2014; Wingborg \& Fredén, 2011). A relatively large amount of literature and research has accumulated and there is a general consensus on the main effects.

We know that non-EU labour migration to Sweden increased after the 2008 policy change. However, this increase has been modest. One of the early follow-ups by the OECD (2011) shows that there has been no substantial increase in the number of work permits, which may be due to the economic crisis and the newness of the law. The report also notes that the reform has provided opportunities for recruitment to businesses and professions that were previously excluded, resulting in half of the work permits and most of the longer permits being granted for occupations which have no labour shortage. These results are confirmed in my two articles in this thesis (Emilsson, 2014a, 2016), as well as in many other studies (Calleman \& Herzfeld Olsson, 2015; Emilsson et al., 2014).

My articles also highlight the need to differentiate between circular/temporary labour migration and labour migration of a more permanent kind in order to understand the effects of the policy change. In the Swedish statistical registries, only those with an intended stay of more than a year are registered. This way we can separate the temporary from the more-permanent labour migrants even though both categories are admitted under the same "track". Using work permit data from the Migration Board, we know that the bulk of the work permits belong to one of three categories: low-skilled jobs in the private service sector, high-skilled jobs as computer specialists and civil engineers, and berry-pickers doing seasonal work. The labour immigrants also tend to come from just a few countries, to just a few professions - berry-pickers from Thailand, computer specialists from India, chefs from China. However, looking only at those included in the population registry, the labour migrant composition is very different. Those proposing to work in high-skilled jobs are mostly circular migrants coming to Sweden as temporary workers in shortterm projects. This is even more obvious for berry-pickers, who are seasonal workers, and of whom very few stay. Hence, those who remain more permanently in Sweden are negatively selected if one considers both education and occupation. 
One of the main findings in my second article is that the policy change did affect the status of labour migrants (Emilsson, 2016). Labour migrants coming after the policy change more often work in occupations where there is already a surplus of workers and have, on average, lower incomes than those under the old labour migration law. The lower average income is in large part explained by the changing composition of labour migrants. Thus, the 2008 labour migration policy has not achieved its main goal of increasing labour migration to shortage occupations. Actually, the outcome has been the opposite, with increasing labour migration to occupations where there is a surplus of workers.

While my articles do not specifically study the eventual exploitation of migrant workers or any employer abuse of labour migration regulations, the income levels which labour migrants declared in surplus occupations are a strong indicator that many of them work under worse conditions than natives. This is also confirmed in other studies. Emilsson et al. (2014) show that, in some occupations in the private service sector, the average income is as low as 10,000 SEK per month. A case study on Chinese restaurant workers concluded that the new labour immigration policy has not succeeded in establishing working conditions for Chinese workers in the restaurant industry that conform to the Swedish Migration Board's guidelines or comply with Swedish labour and employment law (Axelsson et al., 2013:44). In the summary of the anthology on the 2008 reform, Calleman and Herzfeld Olsson (2015) conclude that all the evidence suggests that immigrant workers often receive a lower salary than that specified in the employment contract and have worse working conditions than native workers.

There have been efforts to combat abuse and exploitation. In January 2012 the Migration Board tightened the requirements for work permits in certain industries (e.g. cleaning, hotel and restaurant, service, construction, agriculture and forestry). This somewhat reduced the number of work permits allocated in low-skilled occupations such as restaurant work and cleaning. Later, the government presented a bill (Bill 2013/14:227) on certain measures designed to detect and stop the abuse of labour migrants. The interesting aspect is that the many reports of abuse and low wages in low-skilled occupations with a surplus of available domestic workers (reported by both the police 
and the Migration Board) did not lead to any suggestions to change the policy for selecting migrants. The bill only suggested more postmigration controls. Thus, the principles behind the labour migration policy are not questioned. Overall, the policy discussion has been about whether or not the rules and regulations are followed, not whether the rules and regulation are having positive outcomes on the economy and the labour market.

Another effect of the legislation, which I highlight in my second article, is the frequent mix-up between labour migration and the asylum migration system (Emilsson, 2016). Most of the failed asylumseekers who apply for and/or receive a work permit have low-skilled jobs with a very low income. In addition, many labour migrants use the possibility of obtaining a work permit and visa to gain access to the asylum system.

To summarise, the Swedish 2008 model for labour migration has produced unintended effects. There is clearly a gap between what the government said they wanted from the reform - to facilitate labour migration to shortage occupations - and the outcome. There are primarily two unintended effects: first, a relatively large inflow of workers to low-skilled occupations without labour shortages; second, employers in sectors without any obvious need to look for workers outside of Sweden hire third-country nationals for lower wages and worse working conditions than is legal in Sweden. There are also strong substitution effects, where the labour migration model has had substantial impacts on the asylum system.

\section{Explaining the results}

My articles also help to explain policy outputs when a welfare state, such as the Swedish one, introduces a demand-driven policy without labour market tests. There are both demand and supply factors that can help us to understand the outcome, and the role of social networks that shape the connections between supply and demand. I also highlight some explanations for the exploitation and abuse connected to the 2008 law.

\section{Demand-side explanations}

The demand for foreign workers is low in most sectors of the Swedish labour market (Emilsson et al., 2014). In only a few of the occupations where there are labour shortages, notably computer specialists and 
civil engineers, have a substantial number of non-EU migrant workers been recruited. In most other shortage occupations, such as teaching, medicine and nursing, one needs to speak the language and/or have a special accreditation to be employable. A demand-driven labour migration policy, such as that in Sweden, is not tailored to meet these labour market needs.

The inflow of labour migrants who stay for longer periods is concentrated in the more unregulated private service sector where it is difficult for unions and authorities to enforce wage standards and collective agreements. As I show in my second article (Emilsson 2016), most labour migrants in these sectors of the market have an income well below industry standards. Chaloff and Lemaître (2009) suggest that demand- and supply-driven models suit countries differently depending on each one's characteristics. According to the authors, language barriers make it difficult to directly employ foreign workers. Therefore, demand-driven labour migration is not suitable for countries with languages that are not widely spoken internationally. For such countries, they suggest a supply-driven model in combination with good access to language training for newly arrived immigrants.

\section{Supply-side explanations}

It is obvious that supply factors play a very important role for the effects of the 2008 law on labour migration. From my and others' research (Calleman \& Herzfeld Olsson, 2015; Emilsson et al., 2014; Vogiazides and Hedberg, 2013), we know that the increase in labour migration to low-skilled occupations has less to do with demand for migrants' specific skills, and more to do with supply factors. There are many persons who want to leave their country of origin regardless of there being a demand for their labour or not. To leave a difficult or hopeless situation and get a work visa to Sweden and Europe is, for a large proportion of labour migrants, a stronger driving force than moving to a specific job. The demand-driven labour migration model provided a new opportunity structure for migrating to Sweden besides the asylum system. There are clear indications that labour migration for some has become a substitute to the asylum route, which has led to a mixing of labour migration and the asylum system (Emilsson et al., 2014). 


\section{Social networks}

My first article on labour migration to Sweden shows that international networks are central to any understanding of the outcomes of the reform (Emilsson, 2014a). The new law significantly reduced the power of the state to control migration flows. Through liberalisation, both market forces and kinship networks can play out more freely (Hollifield, 2004). All the three major flows of labour migration to Sweden - high-skilled computer specialists and civil engineers, lower-skilled workers in the private service sector and berry-pickers - are to a large extent dependent of established transnational networks. However, labour migration into low-skilled occupations is especially dependent on personal and international networks. Small companies owned by co-nationals recruit a majority of low-skilled labour migrants. This confirms earlier research that emphasises the importance of migration intermediaries in shaping recruitment, selection and placement, thereby in part determining labour market outcomes for particular groups of migrant workers (Van den Broek et al., 2016).

In Emilsson (2014a) I also emphasise the need to analyse and explain different inflows of labour migrants separately, as they are the result of different driving forces. The inflow of high-skilled workers is best understood as part of a circular migration regime in highly competitive sectors of the globalised economy. On the other hand, the large majority of the migrants to low-skilled jobs come to Sweden for the same reasons as humanitarian migrants - to escape difficult political and socio-economic living conditions in their country of origin. The presence of seasonal labour migration, dominated by the berry-picking industry where the domestic labour force is unwilling to work, is probably best understood within a dual labour market framework.

\section{Exploitation and abuse}

One explanation for the exploitation of migrant workers and the abuse of labour migration regulations is the way in which the law is constructed (Calleman \& Herzfeld Olsson, 2015). Labour migrants are very dependent on the goodwill of the employer who, at any time, can terminate the contract. It is also possible to find explanations on the employer side. Many labour migrants are willing to work for very low wages. Vogiazides and Hedberg (2013:225-236) have carried 
out an in-depth study of labour migration to the restaurant sector and the berry-picking industry; they confirm a widespread trade in work permits. It is common practice for such migrants to pay high fees to middlemen in order to get a work permit. In many cases, especially in the restaurant sector, workers are paid significantly less and work longer hours than was stated in the employment offer given to the Swedish Migration Board for their assessment of the work permit. While some labour migrants are deceived by employers and middlemen, in many cases the migrants are aware that the conditions in the employment offer will not be met in reality.

The results therefore support the observation by Papademitiriou and Sumption (2011) that demand-driven labour migration models tend to be open to abuse and employer manipulation. Boswell and Geddes (2011) also claim that the risk of abuse in demand-driven models is greater in countries where minimum wages are relatively high and employment protection legislation is quite extensive. In an overview paper on what we know about regulating the recruitment of migrant workers, Agunias (2013) highlights the vulnerable position of low-skilled migrant workers. In a competitive international labour market, where the supply of labour typically outweighs demand, regulating private recruitment operations is essential, according to Agunias. The fierce competition for jobs, coupled with poor monitoring and enforcement of rules and regulations, make migrants - especially in the low- and mid-skilled sectors - vulnerable to abuse and exploitation. Since competition for the jobs is fierce, there will often be fees for employment contracts. The "fee is not determined by the financial value of the good procured but by the demand itself... What the recruiter gets is not a fee for the recruiter service but a 'bribe' to the job he or she offers" (Abella, 2004). On the other hand, in sectors with a high demand, recruitment fees are typically not paid by migrant workers but are collected from employers (Agunias, 2013). 


\section{INTEGRATION POLICY AND THE STATE}

The study of integration policies is very diverse and covers too many topics to cover in this introduction to my thesis. I will therefore limit my discussion to the study of the governance of integration policies, which also is the main topic of my two articles (Emilsson 2014a, 2016). The essence of policies is the intention to guide and steer processes in society - in our case, the integration processes of immigrants. The study of integration processes and migrants' integration trajectories as such is therefore excluded from the thesis.

The disposition of the chapter is as follows. In the first part, I present some of the methods and frameworks used when studying integration policies. Next, I discuss two widely debated topics in integration research: the local turn and civic turn. In the final part I present my articles' research findings in relation to the two first parts.

\section{Frames, measures and governance}

Penninx and Garcés-Mascareñas (2016) identify three different components in the study of integration policies: frames, measures and governance.

Integration policy frames are the ideological/philosophical aspect of integration policies. A frame involves the problem definition of a policy issue, including the underlying assumptions of the problem's causes and remedies. Another aspect of a frame is what should be done. Finally, a third aspect is the target group - for whom are integration policies meant? ${ }^{19}$ Frame analysis is usually focused on

19 One common distinction is to differentiate between policies for migrant newcomers and moreestablished immigrant groups. Another common distinction is between targeted or mainstreamed integration policies (Borevi, 2002). 
policy documents and public debates in order to elucidate integration models or integration discourses. This kind of analysis has been used to identify national philosophies of integration (Favell, 1998) or models of integration (Koopmans \& Statham, 2000). In recent years, frame analysis has also been used to question these philosophies and models of integration by revaluating them and by showing a policy divergence between national and local levels of government (Bak Jørgensen, 2012; Duyvendak \& Scholten, 2012).

Integration policy measures refer to the programmes in place. What are the main goals and who do they target? Measures are what are actually done, beyond the rhetoric of political debate. As Dahlström (2004) shows in his dissertation about Swedish integration policies, frames and measures can develop in different directions independent of each other and therefore it is important to take both into account (see the section My contributions: The Swedish and Danish case). When studying policy measures it is common to make an analytical distinction between three separate integration policy domains: (i) the legal-political, (ii) the socio-economic, and (iii) the socio-cultural (Alexander, 2007; Biezeveld \& Entzinger, 2003; Freeman, 2004; Penninx \& Garcés-Mascareñas, 2016; Samers, 2010). The socioeconomic dimension captures a broad category of policy areas like the labour market, education, housing, healthcare, social security and policing. The socio-cultural dimension captures the more subjective and interactive dimension of migrant integration. This dimension involves various policies that refer to processes of acculturation on behalf of migrants. The legal-political dimension captures primarily the civic and political incorporation of migrants into society. The legal part of this refers, for instance, to access to citizenship, antidiscrimination legislation and legal provisions that are specific to migrant groups.

Integration policy governance is about how integration policies are organised and implemented, which means taking into account a wider range of actors, including other administrative levels such as regional and local governments. Penninx and Garcés-Mascareñas (2016) argue that the vertical dimension of integration policymaking, the relationship between the national, regional and local levels, is of particular importance, as both municipalities and the European Union (EU) level have become increasingly involved in the making of immigrant policies. 
As will become clear in subsequent sections, it is of the utmost importance to distinguish which component of integration policies is being studied - frames, measures or governance - since it clearly impacts on the results. After this presentation of the different frameworks for studying integration policies, we now turn to two of the most discussed topics in current integration policy research: the local turn and the civic turn.

\section{National models of integration}

The study of integration policies is heavily influenced by the idea of national models of integration. The books by Brubaker (1992) about citizenship policies in France and Germany and Favell (1998) about immigrant policies in France and Britain both contributed to the establishment of this idea. Their argument is that historical factors connected to nation-building still influence policymaking in individual countries. Brubaker (1990: 387) claims that the policies and politics of citizenship for immigrants remain strikingly different in France and Germany. The two countries have resisted pressures of policy convergence due to their distinctive traditions of national self-understanding grounded in differing historical paths to nationstatehood. In France, the conception of nationhood has been universalist, rationalist, assimilationist and state-centred, while the German conception has been particularist, organic, differentialist and Volk-centred. Favell (1998:2) argues that immigrant policies rest on different philosophies based on contrasting understandings of citizenship and nationality that are held across political parties. In France, the dominant framework is the republican idea of citizenship and belonging, while Britain addresses similar issues in terms of the management of race relations and multiculturalism. These different philosophies, Favell argues, create distinct political responses to immigration. Thus, the national models of integration connect France with a republican idea of citizenship and belonging, Britain with multi-culturalism or a race relations philosophy and Germany with an ethnic model. Other researchers have stressed the importance of historical legacies of colonialism (Hansen, 2002) and the timing of democratisation (Howard, 2009) as determinants for countries' national models, which are, sometimes, grouped together. The search for national integration models often starts by sketching out 
a theoretical typology, with individual countries then being classified as belonging to one or other of these models. For example, Castles et al. (2014:266-270) differentiate between four models for migrant incorporation: assimilation, differential exclusion, integration and multiculturalism.

Regardless of the kind of classification used, the idea of national models rests on the assumption that historical legacies determine integration policies and make countries' policies different from each other. This idea has been challenged by many. Next, I discuss two of these challenges: the local turn and the civic turn in integration policies.

\section{The "local turn" versus the "civic turn" in integration policy}

Researchers have identified two major trends in integration policymaking - a local and a civic turn. The two policy trends do seem to go against each other. The local turn would imply less state involvement, where cities handle more of the integration policies. On the other hand, the civic turn implies ever-more requirements of immigrants, requirements decided by states that have an impact on the lives of migrant newcomers. Nevertheless, the two identified "turns" have one thing in common and that is that they question and challenge the idea of national models of integration. My articles (Dekker et al., 2015; Emilsson, 2015) on the multi-level governance of integration policies tap into this puzzle. First, there is a need to discuss these two topics in more detail.

The local turn

The idea of the local turn is an important and significant critique of earlier understandings of migrant integration policies that have often been defined in terms of national models of integration (Brubaker, 1992; Castles \& Miller, 2009; Favell, 1998; Koopmans \& Statham, 2000). The claim is that the state level has lost importance due to new forms of local integration policies (Alexander, 2003, 2007; Caponio \& Borkert, 2010; Penninx, 2009; Penninx et al., 2004). The local turn suggests that local governments, large cities in particular, are becoming increasingly entrepreneurial in developing their own integration philosophies and policies (de Graauw \& Vermeulen, 2016; Scholten \& Penninx, 2016). Thus, local governments do 
not just implement national policies, but are policymakers as well (Alexander 2003, 2007; Caponio \& Borkert, 2010; Penninx, 2009; Penninx et al., 2004). Recent studies have provided a number of explanations for congruencies and incongruences between local and national policies as well as between local policies in different cities (Bak Jørgensen, 2012; Borkert \& Bosswick, 2007; Poppelaars \& Scholten, 2008). Some scholars argue that there is a specific local dimension of integration policies characterised by a greater tendency to accommodate ethnic diversity and solve integration problems in pragmatic ways - the local pragmatism thesis (Bak Jørgensen, 2012; Caponio \& Borkert, 2010; Poppelaars \& Scholten, 2008). In contrast, others have claimed that there are neither national nor local models of integration, arguing that local policies are uniquely shaped by the specific problem or political and policy settings in the different cities - the localist thesis (Alexander, 2003; Mahnig, 2004).

Scholten (2013) distinguishes between four ideal-type configurations of relations between government levels: centralist (top down), localist (bottom up), multilevel and decoupled (also see Scholten \& Penninx, 2016). First of all, the centralist ideal type exhibits a clear hierarchy and division of labour between government levels. This involves a top-down relationship between the different levels of government to ensure that policy implementation at the local level follows central rules and reflects the central policy frame. The centralist type is expected to produce policy convergence between the different levels of government. As such, this type of governance setting corresponds with the idea of national models of integration. The second ideal type involves a more localist and bottom-up perspective on governance in multilevel settings. In this type, local governments do more than just implement policy; they formulate policies, respond to local policy agendas and exchange knowledge and information horizontally with other local governments. The localist type may lead to greater policy divergence between the national and the local levels. As distinct from these centralist and localist types, multilevel governance refers to the interaction and joint coordination of relations between the various levels of government without clear dominance of any one level. This means that "vertical venues" are needed where governments from different levels jointly engage in meaningful policy coordination. The fourth type is decoupled relations between government levels. 
Such a situation is characterised by the absence of any meaningful policy coordination between the levels. Thus, in any single policy domain, policies at different levels are dissociated and may even be contradictory.

The civic turn

The introduction of civic integration policies has been one of the most significant policy developments in Europe over the last two decades, implying a civic turn in integration policies (Gebhardt, 2015; Goodman, 2010, 2012a, 2012b; Joppke, 2007). The civic turn suggests that states are introducing integration requirements, such as language skills and civic orientation exams, in order for immigrants to become permanent residents and later citizens. Civic integration policies are also part of migration control, forcing immigrants to be successful in order to stay securely in the country and bring family members for reunification or family formation. This challenges the idea of national models for integration since the introduction of civic integration policies implies a convergence of policies between countries.

The Dutch Newcomers Act of 1998 is often seen as the first example of civic integration policies, but there have been many followers. Countries like Denmark, Germany, Austria, Netherlands, the UK and France, in particular, introduced many civic integration policy instruments between 1997 and 2009 (Goodman 2010). Central features are obligatory integration requirements for immigration, permanent residence and citizenship. The introduction of these requirements has shifted the burden of adjustment towards the individual migrant. The underlying aim is generally to promote individual autonomy and common values for newcomers. In other words, liberal goals are promoted by illiberal means (Groenendijk et al., 2009; Joppke, 2007).

While few doubt the presence of a civic turn in Western European countries' integration polices, there are disagreements about how to measure and compare it (Goodman 2012b; Michalowski \& van Oers, 2012), and about the degree of convergence which civic integration policies have brought about. Mouritsen (2012), looking at civic integration policies in Denmark, Germany and the UK, acknowledges that there have been tendencies towards liberal convergence. However, 
he argues that the countries' policies still reflect continuities, and path-dependent reactions to such continuities, of culturally bounded nation states. He refers to the national contexts as national cultural spaces "reflecting state structures, institutional entrenchments and identity references of agony, pride or self-doubt" (Ibid. p. 104). In a similar way, Goodman (2012a) emphasises variations in the new civic integration policies between countries as products of existing citizenship policies. In countries where opportunities to naturalise are already limited, civic integration policies are set up in order to further disincentivise naturalization. On the other hand, in countries with liberal citizenship regimes, civic integration policies aim to incentivise participation and inclusion. Based on this observation, Goodman argues that civic requirements are not a sign of national convergence, but a reaffirmation of national approaches to citizenship.

\section{My contributions}

My two articles (Dekker et al., 2015; Emilsson, 2015) on the multilevel governance of integration policies make two main contributions to the field of integration policy studies. The first relates to the connection between research method and research findings in the study of the multi-level governance of integration policy. The second relates to the role of the state, where I argue that we are witnessing a national turn in local integration policy. Before returning to my main contributions, I present the content and results of the two articles:

\section{Article 1. A Local Dimension of Integration Policies? A Compara- tive Study of Berlin, Malmö, and Rotterdam}

The aim of the article is to explore the extent to which there is a specific local dimension to migrant integration policies, and how this can be explained. The article explores three theses about local integration policies - national models of integration thesis, the local pragmatism thesis, and the localist thesis - in three European cities: Berlin, Malmö and Rotterdam. Selecting three cities with relatively large migrant populations but from three countries with different national integration philosophies allows us to capture differences on the national-local as well as the local-local dimension.

This question is differentiated into three sub-questions. First, to what extent are there congruences or incongruences between national 
and local policies (the vertical dimension)? Second, to what extent are there congruences and incongruences between local policies in the various cities (the horizontal dimension)? Thirdly, to what extent can such horizontal and vertical congruences and incongruences be explained by governance structures or the specific local and national problem context in the examined cases? To answer these questions, we analysed the relevant national and local policy documents over the period 2005-2012 and interviewed policymakers from the three cities.

The article concludes that the local pragmatism thesis does not hold for Berlin, Malmö or Rotterdam. Neither are the policies structurally more accommodative towards migrants than the national policies, nor do they resemble each other in that way. Evidence supports both the national models thesis and the localist thesis to a certain extent, but neither explanation is fully supported. Local integration policies resemble their national policies to a great extent, but not due to strict top-down hierarchical government structures. They can better be described as two-way multilevel interaction.

\section{Article 2. A National Turn of Local Integration Policy: Multi-Level Governance Dynamics in Denmark and Sweden}

The aim of the article is, again, to see whether there is a local or a national turn in local integration policies and how this has come about. The cases studied are Denmark and Sweden - two countries with similar welfare states and local government structures (Sellers \& Lindström, 2007) but with very different national integration policies (Brochmann \& Hagelund, 2012).

Contrary to most research, the article argues that what we are witnessing is a national turn in local integration policy, where local integration policies and practices are increasingly governed by the state. Despite different integration policies in Denmark and Sweden I show that, in recent years, the governments of the two countries have increased their control and local influence and thereby limited the possibilities for local governments to formulate their own integration policies. The centralisation of local integration policies has occurred in both cases, albeit in a different way and using different strategies. The increased interference of national governments in local integration policies takes the form of laws and regulations that force local 
municipalities to implement certain integration measures, by means of increased state funding for measures implemented at the local level and increased direct state involvement in the implementation of local integration policies. Last but not least, in Denmark, state legislation has had an increasing impact on the lives of individual migrants.

\section{Policy frames or policy measures}

The first article shows ambiguous results. It largely supports the idea of the local turn in integration policy. It also emphasises that the integration policies, in cases with top-down governance structures, are based on two-way multilevel interaction. The findings in the second article largely contradict those in the first, and claim that we are witnessing a national, rather than a local, turn in integration policies. How can these contradictory results be explained?

I argue that the method/object of study strongly influences the results. Where the first article studies integration policy frames on the local and national levels in different countries, the second article studies integration policy measures. This distinction between studying frames and measures is an important one, and explains why, in the second article, we find results that contradict most other research on local integration policies, research that has predominantly used frames as the object of study (see Figure 1).

Figure 1. Typology of the study of the multi-level governance of integration policies

\begin{tabular}{|l|c|c|c|}
\hline & Socio-cultural & Socio-economic & Legal-political \\
\hline Frames & \multicolumn{3}{|c|}{ Article 1 } \\
\hline Measures & & Article 2 \\
\hline
\end{tabular}

One important explanation for why most researchers agree on a local turn in integration policy and that national models of integration are becoming weaker is that they look at the relationship between the local and the national level using frame analysis (see, for example, Bak Jørgensen, 2012; Scholten, 2013). This makes them look at integration policy from a rhetorical perspective, i.e. how an actor defines the problems, diagnoses the causes, makes moral judgements and suggests remedies for integration (D'Angelo \& Kuypers, 2010). Official policy documents are studied with a view to unveiling the 
central organising idea or ideology behind the policies. If local governments are found to adopt official integration policies that are ideologically different to those of the central government, the conclusion is that national models of integration are disintegrating. $\mathrm{I}$, and my co-authors, employed this method in my first article.

However, from my knowledge stemming from over a decade of working on integration policy and from my fieldwork in Malmö, Sweden and Copenhagen, Denmark, I felt that the method did not properly capture what is happening in integration policy governance. What previous research on local integration policies has often missed when mainly looking at policy frames are changes in actual integration measures and, in particular, policy changes in the legal-political domain, such as civic integration policies (Goodman, 2010; Joppke, 2007) that have profound consequences for both local governments and immigrant newcomers in most countries. My impression was that frame analysis failed to address the power relationship between national and local governments. I therefore decided to analyse the multi-level governance of integration using a theoretical model inspired by Etzioni (1975), which was originally developed to compare complex organisations. The model's main advantage is that it captures the power relations between those higher and lower in rank. The central concept in Etzioni's book is compliance, which he sees as a key element in all organisations. Compliance relations are asymmetric and vertical. They are about how subordinated actors behave in relation to another actor's power, and how those in power make other actors follow their directives. When I applied Etzionís model to my study of changes in integration policy measures on the local level in Denmark and Sweden, I found that what we are witnessing is a national turn in local integration policy, where these policies and practices are increasingly governed by the state. Despite different integration policies in Denmark and Sweden I show that, in recent years, the governments of the two countries have increased their control and local influence and thereby limited the possibilities for local governments to formulate their own integration policies.

The conclusion from this is that the use of policy frames as an object of study has hidden the fact that an increasing number of local integration measures are, in fact, financed and determined by the state. This highlights the need to complement earlier research based 
on frame analysis with an analytical framework that looks at policy measures and takes central government steering and the uneven power relationship between the levels of government into account.

\section{The centralisation of integration policies and the civic turn}

Despite the fact that Denmark and Sweden have chosen very different integration policies - Denmark being a country with a strict civic integration regime whilst Sweden lacks civic integration policies altogether (Goodman, 2012b) - both countries have experienced a national turn in integration policies during recent decades. Thus, Sweden and Denmark have diverged when it comes to integration policy measures and frames, but converged in a strong centralistic governance model.

In Denmark and other countries, civic integration policies have led to a reassertion of state power over the lives of individual migrants (Hansen, 2009:15) and brought the state closer to the individual (Goodman, 2012a:693). Regardless of civic integration policies being used as a tool for exclusion or inclusion, it signals that the state takes responsibility for ensuring integration while the individual is directly accountable to the state. In this new context, local governments have very little discretion. However, civic integration policies cannot explain the national turn in local integration policies in the case of Sweden, where the individual has fewer responsibilities towards the state. Here, the state has used its power to reduce local governments' policy discretion by, for example, centralising the administration of the introduction programmes.

My results could support the idea of national models of integration. However, this explanation has two major weaknesses. First, if Denmark has converged to the general trend of civic integration policies and Sweden not, it would simply mean that Sweden is an outlier of a general convergence of civic integration policies. Second, since the integration policy measures in Sweden and Denmark did not substantially diverge until the late 1990s, the different policy choices could not be a direct result of historically determined ideas about nationhood. 


\section{REFERENCES}

Abella, M. (2004) The Role of Recruiters in International Migration, in Massey, D.S. \& Taylor, J.E. (eds.), International Migration: Prospects and Policies in a Global Market, London, Oxford University Press, pp. 201-211.

Afonso, A. (2014) How to Please Voters Without Alienating Friends? Parties, Organised Interests and Advocacy Coalitions in Swiss Immigration Policy, Comparative European Politics, 12(6), pp. 568-583.

Agunias, D.R. (2013) What We Know About Regulating the Recruitment of Migrant Workers, Policy Brief 6, Washington DC, Migration Policy Institute.

Akkerman, T. (2015) Immigration Policy and Electoral Competition in Western Europe. A Fine-Grained Analysis of Party Positions over the Past Two Decades, Party Politics, 21(1), pp. 54-67.

Axelsson, L., Hedberg, C., Zhang, Q. \& Malmberg, B. (2013) Chinese Restaurant Workers in Sweden: Policies, Patterns and Social Consequences, Geneva, International Organization for Migration.

Alexander, M. (2003) Local Policies Toward Migrants as an Expression of Host-Stranger Relations: A Proposed Typology, Journal of Ethnic and Migration Studies, 29(3), pp. 411-430.

Alexander, M. (2007) Cities and Labour Immigration: Comparing Policy Responses in Amsterdam, Paris, Rome and Tel Aviv, Aldershot, Ashgate.

Bak Jørgensen, M. (2012) The Diverging Logics of Integration Policy Making at National and City Level, International Migration Review, 46(1), pp. 244-278.

Balch, A. (2010) Managing Labour Migration in Europe: Ideas, Knowledge and Policy Change, Manchester, Manchester University Press.

Balch, A. (2016) Borders, Immigration and State Transformation, in Kavalski, E. (ed.), Encounters with World Affairs: An Introduction to International Relations, London and New York, Routledge, pp. 329-346. 
Banting, K. (2000) Looking in Three Directions. Migration and the European Welfare State in Comparative Perspective, in Bommes. M. \& Geddes, A. (eds.), Immigration and Welfare. Challenging the Borders of the Welfare State, London and New York, Routledge, pp. 13-33.

Barthel, F. \& Neumayer, E. (2015) Spatial Dependence in Asylum Migration, Journal of Ethnic and Migration Studies, 41(7), pp. 1131-1151.

Becker, G.S. (1993) Human Capital: A Theoretical and Empirical Analysis, with Special Reference to Education (Third Edition), Chicago, University of Chicago Press.

Bedford, R. \& Spoonley, P. (2014) Competing for Talent: Diffusion of an Innovation in New Zealand's Immigration Policy, International Migration Review, 48(3), pp. 891-911.

Berg, L. \& Spehar, A. (2013) Swimming Against the Tide: Why Sweden Supports Increased Labour Mobility Within and From Outside the EU, Policy Studies, 34(2), pp. 142-161.

Bevelander, P. \& Dahlstedt, I. (2012) Sweden's Population Groups Originating from Developing Countries: Change and Integration, Current Themes in IMER Research 12, Malmö, Holmbergs.

Bevelander, P., Emilsson, H. \& Hagström, M. (2008) Asylsökandes Eget Boende, EBO - en Kartläggning, Karlskrona, Boverket.

Biezeveld, R. \& Entzinger, H. (2003) Benchmarking in Immigrant Integration, Rotterdam, Erasmus University.

Bill 1975:26 Regeringens proposition om riktlinjer för invandrar- och minoritetspolitiken m.m.

Bill 1985/86:98 Om Invandrarpolitiken.

Bill 1997/98:16 Sverige, framtiden och mångfalden - från invandrarpolitik till integrationspolitik.

Bill 2009/10:31 Genomförande av skyddsgrundsdirektivet och asylprocedurdirektivet.

Bill 2009/10:60 Nyanlända Invandrares Arbetsmarknadsetablering Egenansvar med Professionellt Stöd.

Bill 2013/14:227 Åtgärder mot missbruk av reglerna för arbetskraftsinvandring.

Bill 2015/16:54 Ett Gemensamt Ansvar för Mottagande av Nyanlända.

Bill 2015/16:174 Förslag om att Tillfälligt Begränsa Möjligheten att få Uppehållstillstånd i Sverige.

Bjerre, L., Helbling, M., Römer, F. \& Zobel, M. (2015) Conceptualizing and Measuring Immigration Policies: A Comparative Perspective, International Migration Review, 49(3), pp. 555-600. 
Bleich, E. (2002) Integrating Ideas into Policy-Making Analysis: Frames and Race Policies in Britain and France, Comparative Political Studies, 35(9), pp. 1054-1076.

Bonjour, S. (2011) The Power and Morals of Policy Makers: Reassessing the Control Gap Debate, International Migration Review, 45(1), pp. 89-122.

Borevi, K. (2002) Välfärdsstaten i det Mångkulturella Sambället, Uppsala, Acta Universitatis Upsaliensis.

Borevi, K. (2012) Sweden: The Flagship of Multiculturalism, in Brochmann, G. \& Hagelund, A (eds.), Immigration Policy and the Scandinavian Welfare State 1945-2010, London, Palgrave Macmillan, pp. 25-96.

Borkert, M. \& Bosswick, W. (2007) Migration Policy-Making in Germany: Between National Reluctance and Local Pragmatism? IMISCOE Working Paper 20, Amsterdam, IMISCOE.

Boswell, C. (2007) Theorizing Migration Policy: Is There a Third Way? International Migration Review, 41(1), pp. 75-100.

Boswell, C. \& Geddes, A. (2011) Migration and Mobility in the European Union, Basingstoke, Palgrave Macmillan.

Boswell, C., Geddes, A. \& Scholten, P. (2011) The Role of Narratives in Migration Policy-Making: A Research Framework, The British Journal of Politics \& International Relations, 13(1), pp. 1-11.

Brettell, C.B. and Hollifield, J.F. (eds.) (2007) Migration Theory: Talking Across Disciplines (2nd edition), New York and London, Routledge.

Brochmann, G. \& Hagelund, A. (2012) Comparisons: A Model with Three Exceptions? in Brochmann, G. and Hagelund, A. (eds.), Immigration Policy and the Scandinavian Welfare State 1945-2010, New York, Palgrave Macmillan, pp. 225-275.

Bucken-Knapp, G. (2007) Varieties of Capitalism and Labor Migration Policy, Preprint 2007:1, Trollhättan, Högskolan i Väst.

Bucken-Knapp, G. (2009) Defending the Swedish Model. Social Democrats, Trade Unions, and Labor Migration Policy Reform, Lanham MD, Lexington Books.

Brubaker, R. (1990) Immigration, Citizenship, and the Nation-State in France and Germany: A Comparative Historical Analysis, International Sociology, 5(4), pp. 379-407.

Brubaker, R. (1992) Citizenship and Nationhood in France and Germany, Cambridge MA, Harvard University Press.

Buzan, B. (1993) Societal Security, State Security and Internationalisation, in Wæver, O., Buzan, B., Kelstrup, M. \& Lemaitre, P. (eds.), Identity, Migration and the New Security Agenda in Europe, London, Pinter, pp. 41-58. 
Calleman, C. \& Herzfeld Olsson, P. (2015) Avslutande Reflektioner, in Calleman, C. \& Herzfeld Olsson, P. (eds.), Arbetskraft Från Hela Världen: Vad Hände med 2008 Års Reform?, DELMI Rapport 2015:9, Stockholm, DELMI.

Caponio, T. \& Borkert, M. (2010) The Local Dimension of Migration Policymaking, Amsterdam, Amsterdam University Press.

Castles, S. \& Miller, M.J. (2009) The Age of Migration. International Population Movements in the Modern World, New York, Palgrave Macmillan.

Castles, S., de Haas, H. \& Miller, M.J. (2014) The Age of Migration: International Population Movements in the Modern World, New York, Palgrave Macmillan.

Caviedes, A. (2010) Towards a European Model for High Skilled Labour Migration? in Luedtke, A. (ed.), Migrants and Minorities: The European Response, Newcastle upon Tyne, Cambridge Scholars, pp. 61-81.

Cerna, L. (2009) The Varieties of High-Skilled Immigration Policies: Coalitions and Policy Outputs in Advanced Industrial Countries, Journal of European Public Policy, 16(1), pp. 144-161.

Cerna, L. (2016) The Crisis as an Opportunity for Change? High-Skilled Immigration Policies Across Europe, Journal of Ethnic and Migration Studies, 42(10), pp. 1610-1630.

Chaloff, J. (2014) Evidence-Based Regulation of Labour Migration in OECD Countries: Setting Quotas, Selection Criteria, and Shortage Lists, Migration Letters, 11(1), pp. 11-22.

Chaloff, J. \& Lemaître, G. (2009) Managing Highly-Skilled Labour Migration: A Comparative Analysis of Migration Policies and Challenges in OECD Countries, OECD Social, Employment and Migration Working Papers, No. 79, Paris, OECD.

Cornelius, W.A. \& Tsuda, T. (2004) Controlling Immigration: The Limits of Government Intervention, in Cornelius, W., Tsuda, T., Hollifield, J. \& Martin, P. (eds.), Controlling Immigration: A Global Perspective, Stanford Ca, Stanford University Press, pp. 1-48.

Czaika, M. \& de Haas, H. (2013) The Effectiveness of Immigration Policies, Population and Development Review, 39(3), pp. 487-508.

Czaika, M., \& Parsons, C. (2015) The Gravity of High Skilled Migration Policies, IMI Working Paper Series, Oxford, International Migration Institute \& University of Oxford.

Dahlström, C. (2004) Nästan Välkomna: Invandrarpolitikens Retorik och Praktik, Göteborg, Göteborgs Universitet.

D’Angelo, P. \& Kuypers, J.A. (2010) Doing News Framing Analysis, New York, Routledge. 
Dauvergne, C. \& Marsden, S. (2014) The Ideology of Temporary Labour Migration in the Post-Global Era, Citizenship Studies, 18(2), pp. 224-242.

Desiderio, M.V. \& Hooper, M. (2016) The Canadian Expression of Interest System: A Model to Manage Skilled Migration to the European Union? Brussels, Migration Policy Institute.

de Graauw, E. \& Vermeulen, F. (2016) Cities and the Politics of Immigrant Integration: A Comparison of Berlin, Amsterdam, New York City, and San Francisco, Journal of Ethnic and Migration Studies, 42(6), pp. 989-1012.

de Haas, H. (2011) The Determinants of International Migration, DEMIG Working Paper 2, Oxford, International Migration Institute, University of Oxford.

de Haas, H., Natter, K. \& Vezzoli, S. (2014) Growing Restrictiveness or Changing Selection? The Nature and Evolution of Migration Policies, International Migration Review, Early view.

De Somer, M. (2012) Trends and Gaps in the Academic Literature on EU Labour Migration Policies, CEPS Paper in Liberty and Security in Europe No. 50, Brussels, Centre for European Policy Studies.

Dekker, R., Emilsson, H., Krieger, B. \& Scholten, P. (2015) A Local Dimension of Integration Policies? A Comparative Study of Berlin, Malmö, and Rotterdam, International Migration Review, 49(3), pp. 633-658.

Devitt, C. (2011) Varieties of Capitalism, Variation in Labour Immigration, Journal of Ethnic and Migration Studies, 37(4), pp. 579-596.

Donnelly, J. (2005) Realism, in Burchill, S., Linklater, A., Devetack, R., Donnely, J., Patterson, M., Reus-Smit, C. \& True, J., (eds.), Theories of International Relations, Basingstoke, Palgrave, pp. 29-54.

Downs, A. (1957) An Economic Theory of Democracy, New York, Harper.

Duyvendak, J.W. \& Scholten, P. (2012) Deconstructing the Dutch Multicultural Model: A Frame Perspective on Dutch Immigrant Integration Policymaking, Comparative European Politics, 10(3), pp. 266-282.

Emilsson, H. (2014a) Who Gets In and Why: The Swedish Experience with Demand Driven Labour Migration - Some Preliminary Results, Nordic Journal of Migration Research, 4(3), pp. 134-143.

Emilsson, H. (2014b) Sweden, in Triandafyllidou, A. \& Gropas, R. (eds.), European Immigration: A Sourcebook (2 $2^{\text {nd }}$ edition), Surrey, Ashgate, pp. 351-362.

Emilsson, H. (2015) A National Turn of Local Integration Policy: Multi-Level Governance Dynamics in Denmark and Sweden, Comparative Migration Studies, 3(7), pp. 1-16.

Emilsson, H. (2016) Recruitment to Occupations with a Surplus of Workers: The Unexpected Outcomes of Swedish Demand-Driven Labour Migration Policy, International Migration, 54(2), pp. 5-17. 
Emilsson, H., Magnusson, K., Osanami Törngren, S. and Bevelander, P. (2014) The World's Most Open Country: Labour Migration to Sweden After the 2008 Law, Current Themes in IMER Research Number 15, Malmö, Malmö University.

Employment Service (2016) Prognos för Utbetalningar 2016-2020, Stockholm.

Entman, R.M. (1993) Framing: Toward Clarification of a Fractured Paradigm, Journal of Communication, 43(4), pp. 51-58.

Esipova, N., Ray, J. \& Pugliese, A. (2011) Gallup World Poll: The Many Faces of Global Migration, IOM Migration Research Series 43, Geneva, International Organization for Migration.

Etzioni, A. (1975) A Comparative Analysis of Complex Organizations: On Power, Involvement, and their Correlates, New York, The Free Press.

Eurostat (2016) Asylum in the EU Member States, Luxembourg, Eurostat.

Expert Council of German Foundations on Integration and Migration (2015a) The Canadian Express Entry System, Berlin.

Expert Council of German Foundations on Integration and Migration (2015b) Immigration Countries: Germany in an International Comparison, 2015 Annual Report, Berlin.

Facchini, G. \& Lodigiani, E. (2014) Attracting Skilled Immigrants: An Overview of Recent Policy Developments in Advanced Countries, National Institute Economic Review, 229(1), pp. 3-21.

Facchini, G. \& Mayda, A.M. (2008) From Individual Attitudes Towards Migrants to Migration Policy Outcomes: Theory and Evidence, Economic Policy, 23(56), pp. 652-713.

Faist, T. (2000) Transnationalization in International Migration: Implications for the Study of Citizenship and Culture, Ethnic and Racial Studies, 23(2), pp. 189-222.

Favell, A. (1998) Philosophies of Integration: Immigration and the Idea of Citizenship in France and Britain, Basingstoke, Macmillan.

Finotelli, C. \& Kolb, H. (2015) 'The Good, the Bad and the Ugly' Reconsidered: A Comparison of German, Canadian and Spanish Labour Migration Policies, Journal of Comparative Policy Analysis: Research and Practice, early view, pp. 1-15.

Fischer, F. (2003) Reframing Public Policy: Discursive Politics and Deliberative Practices, Oxford, Oxford University Press.

Freeman, G.P. (1995) Modes of Immigration Politics in Liberal Democratic States, International Migration Review, 29(4), pp. 881-902.

Freeman, G.P. (1998) Toward a Theory of the Domestic Politics of International Migration in Western Nations, South Bend, University of Notre Dame. 
Freeman, G.P. (2004) Immigrant Incorporation in Western Democracies, International Migration Review, 38(3), pp. 945-969.

Freeman, G.P. (2005) Political Science and Comparative Immigration Politics, in Bommes, M. \& Morawska, E. (eds.), International Migration Research: Constructions, Omissions and the Promises of Interdisciplinarity, Burlington Vt., Ashgate, pp. 111-128.

Gebhardt, D. (2015) When the State Takes Over: Civic Integration Programmes and the Role of Cities in Immigrant Integration, Journal of Ethnic and Migration Studies, 42(5), pp. 742-758.

Geddes, A. (2003) The Politics of Migration and Immigration in Europe. London, Sage.

Geddes, A. \& Niemann, A. (2015) Introduction: Conceptualizing EU Policy on Labour Migration, Cambridge Review of International Affairs, 28(4), pp. 523-535.

Goldin, I., Cameron, G. \& Balarajan, M. (2012) Exceptional People: How Migration Shaped our World and Will Define our Future, Princeton \& Oxford, Princeton University Press.

Goodman, S.W. (2010) Integration Requirements for Integration's sake? Identifying, Categorising and Comparing Civic Integration Policies, Journal of Ethnic and Migration Studies, 36(5), pp. 753-772.

Goodman, S.W. (2012a) Fortifying Citizenship: Policy Strategies for Civic Integration in Western Europe, World Politics, 64(4), pp. 659-698.

Goodman, S.W. (2012b) Measurement and Interpretation Issues in Civic Integration Studies: A Rejoinder, Journal of Ethnic and Migration Studies, 38(1), pp. 173-186.

Graham, M. \& Soininen, M. (1998) A Model for Immigrants? The Swedish Corporate Model and the Prevention of Ethnic Discrimination, Journal of Ethnic and Migration Studies, 24(3), pp. 523-539.

Green, A.G., \& Green, D.A. (1995) Canadian Immigration Policy: The Effectiveness of the Point System and Other Instruments, Canadian Journal of Economics, 20(4b), pp. 1006-1041.

Green-Pedersen, C. \& Krogstrup, J. (2008) Immigration as a Political Issue in Denmark and Sweden, European Journal of Political Research, 47(5), pp. 610-634.

Groenendijk, K., Guild, E., \& Carrera, S. (eds.) (2009) Illiberal Liberal States: Immigration Citizenship and Integration in the EU, Farnham, Ashgate.

Gsir, S. (2013) EU Labour Immigration Policy: Discourses and Mobility, Refugee Survey Quarterly, 32(4), pp. 90-111.

Gustafson, P. (2002) Globalisation, Multiculturalism and Individualism: The Swedish Debate on Dual Citizenship, Journal of Ethnic and Migration Studies, 28(3), pp. 463-481. 
Hailbronner, K. \& Koslowski, R. (2008) Models for Immigration Management Schemes: Comparison and Analysis of Existing Approaches and a Perspective for Future Reforms, GMF Paper Series, Washington DC, The German Marshall Fund of the United States.

Hall, P.A. (1993) Policy Paradigms, Social Learning, and the State: The Case of Economic Policymaking in Britain, Comparative Politics, 25(3), pp. $275-296$.

Hall, P. \& Soskice, D. (2001) An Introduction to Varieties of Capitalism, in Hall, P. \& Soskice, D. (eds.), Varieties of Capitalism: The Institutional Foundations of Comparative Advantage, Oxford: Oxford University Press, pp. 1-68.

Hampshire, J. (2013) The Politics of Immigration: Contradictions of the Liberal State, Cambridge, Polity Press.

Hansen, R. (2002) Globalization, Embedded Realism, and Path Dependence: The Other Immigrants to Europe, Comparative Political Studies, 35(3), pp. 259-283.

Hansen, R. (2009) The Poverty of Postnationalism: Citizenship, Immigration, and the New Europe, Theory and Society, 38(1), pp. 1-24.

Hatton, T.J. (2004) Seeking Asylum in Europe, Economic Policy, 19(38), pp. 6-62.

Hatton, T.J. (2011) Seeking Asylum: Trends and Policies in the OECD, London, Centre for Economic Policy Research.

Hawthorne, L. (2005) 'Picking Winners': The Recent Transformation of Australia’s Skilled Migration Policy, International Migration Review, 39(3), pp. 663-696.

Hawthorne, L. (2011) Competing for Skills: Migration Policies and Trends in New Zealand and Australia, Wellington, Department of Labour.

Hedberg, C. \& Fuentes-Monti, A. (2013) Translokal Landsbygd: När Bärplockarna Kommer till Byn, Geografiska Notiser, 71(1), pp. 13-23.

Hellström, A., Nilsson, T. \& Stoltz, P. (2012) Nationalism vs Nationalism: The Challenge of the Sweden Democrats in the Swedish Public Debate, Government and Opposition, 47(2), pp. 186-205.

Hix, S. \& Noury, A. (2007) Politics, Not Economic Interests: Determinants of Migration Policies in the European Union, International Migration Review, 41(1), pp. 182-205.

Hollifield, J.F. (1992) Immigrants, Markets, and States: The Political Economy of Postwar Europe, London, Harvard University Press.

Hollifield, J.F. (2004) The Emerging Migration State, International Migration Review, 38(3), pp. 885-912. 
Hollifield, J.F. (2008) The Politics of International Migration. How Can We 'Bring the State Back In? in Brettell, C.B. \& Hollifield, J.F. (eds.), Migration Theory: Talking Across Disciplines, New York \& London, Routledge, pp. 137-185.

Hollifield, J.F. \& Wong, T.K. (2015) The Politics of International Migration: How Can 'We Bring the State Back In'? in Brettell, C.B., \& Hollifield, J.F. (eds.), Migration Theory: Talking Across Disciplines (Third Edition), New York \& London, Routledge, pp. 227-288.

Howard, M.M. (2009) The Politics of Citizenship in Europe, New York, Cambridge University Press.

Joppke, C. (2007) Beyond National Models: Civic Integration Policies for Immigrants in Western Europe, West European Politics, 30(1), p. 1-22.

Joppke, C. (1998) Why Liberal States Accept Unwanted Immigration, World Politics, 50(2), pp. 266-293.

Kamoltip Kallstrom, J. (2011) Transnational Seasonal Migration and Development: Lives of Thai Berry Pickers Returnees from Sweden, Bangkok, Chulalongkorn University.

Klingemann, H.D., Hofferbert, R.I. \& Budge, I. (1994) Parties, Policies, and Democracy, Boulder CO, Westview Press.

Kolb, H. (2014) When Extremes Converge, Comparative Migration Studies, 2(1), pp. 57-75.

Koopmans, R. \& Statham, P. (2000) Migration and Ethnic Relations as a Field of Political Contention: An Opportunity Structure Approach, in Koopmans, R. \& Statham, P. (eds.), Challenging Immigration and Ethnic Relations Politics: Comparative European Perspectives, Oxford and New York, Oxford University Press, pp. 13-56.

Koslowski, R. (2014) Selective Migration Policy Models and Changing Realities of Implementation. International Migration, 52(3), pp. 26-39.

Lavenex, S. (2001) Migration and the EU's New Eastern Border: Between Realism and Liberalism, Journal of European Public Policy, 8(1), pp. 24-42.

Luik, M.A., Emilsson, H. \& Bevelander, P. (2016) Explaining the Male NativeImmigrant Employment Gap in Sweden: The Role of Human Capital and Migrant Categories, IZA Discussion Paper No. 9943, Bonn, IZA.

Lundh, C. \& Ohlsson, R. (1999) Från Arbetskraftsimport till Flyktinginvandring, Stockholm, SNS Förlag.

Mahnig, H. (2004) The Politics of Minority-Majority Relations: How Immigrant Policies Developed in Paris, Berlin and Zurich, in Penninx, R., Kraal, K., Martiniello, M. \& Vertovec, S. (eds.), Citizenship in European Cities. Immigrants, Local Politics and Integration Policies, Farnham, Ashgate Publishing, pp. 17-37. 
Massey, D.S., Arango, J., Hugo, G., Kouaouci, A. \& Pellegrino, A. (1999) Worlds in Motion: Understanding International Migration at the End of the Millennium, Oxford, Clarendon Press.

Massey, D.S., Durand, J. \& Malone, N.J. (2002) Beyond Smoke and Mirrors: Mexican Immigration in an Era of Economic Integration, New York, Russell Sage Foundation.

Menz, G. (2011) Employer Preferences for Labour Migration: Exploring 'Varieties of Capitalism'-Based Contextual Conditionality in Germany and the United Kingdom, The British Journal of Politics and International Relations, 13(4), pp. 534-550.

Menz, G. \& Caviedes, A. (2010) Introduction: Patterns, Trends, and (Ir) Regularities in the Politics and Economics of Labour Migration in Europe, in Menz, G. \& Caviedes, A., Labour Migration in Europe, Basingstoke, Palgrave Macmillan, pp. 1-22.

Michalowski, I. \& van Oers, R. (2012) How can we Categorise and Interpret Civic Integration Policies? Journal of Ethnic and Migration Studies, 38(1), pp. 163-171.

Migration Board (2007) Swedish Migration Board: Annual Report 2006, Norrköping, Migration Board.

Migration Board (2011) Practical Responses to Irregular Migration into Sweden: A Study Produced by the European Migration Network, Norrköping, Migration Board.

Migration Board (2012) Swedish Migration Board: Annual Report 2011, Norrköping, Migration Board.

Migration Board (2016) Verksambets and Utgiftsprognos April 2016, Norrköping, Migration Board.

Ministry of Employment (2011) Fickfakta 2010 - Statistik om Integration, Stockholm, Ministry of Employment.

Ministry of Justice (2011) Migration Policy, Fact Sheet from the Ministry of Justice, http://www.regeringen.se/contentassets/ aa05e9db0b404d5caed8798a233484c4/migration-policy, Accessed 201608-17.

Mouritsen, P. (2012) The Resilience of Citizenship Traditions: Civic Integration in Germany, Great Britain and Denmark, Ethnicities, 13(1), pp. 86-109.

National Board of Housing, Building and Planning (2015) Boendesituationen för nyanlända, Karlskrona, Boverket.

Neumayer, E. (2004) Asylum Destination Choice: What Makes Some Western European Countries More Attractive than Others? European Union Politics, 5(2), pp. 155-180. 
Neumayer, E. (2005) Asylum Recognition Rates in Western Europe: Their Determinants, Variation, and Lack of Convergence, Journal of Conflict Resolution, 49(1), pp. 43-66.

OECD (2009) Workers Crossing Borders: A Road Map for Managing International Labour Migration, in International Migration Outlook 2009, Paris, OECD, pp. 77-224.

OECD (2011) Recruiting Immigrant Workers: Sweden, Paris, OECD.

OECD (2013) Recruiting Immigrant Workers: Germany, Paris, OECD.

Odmalm, P. (2011) Political Parties and 'the Immigration Issue': Issue Ownership in Swedish Parliamentary Elections 1991-2010, West European Politics, 34(5), pp. 1070-1091.

Ortega, F. \& Peri, G. (2013) The Effect of Income and Immigration Policies on International Migration, Migration Studies, 1(1), pp. 47-74.

Papademitriou, D. \& Sumption, M. (2011) Rethinking Points Systems and Employer Selected Immigration, Washington DC, Migration Policy Institute.

Penninx, R. (2009) Decentralising Integration Policies. Managing Migration in Cities, Regions and Localities, Policy Network Paper November, London, Policy Network.

Penninx, R., Kraal, K., Martiniello, M. \& Vertovec, S. (2004) Citizenship in European Cities. Immigrants, Local Politics and Integration Policies. Farnham: Ashgate Publishing.

Penninx, R. \& Garcés-Mascareñas, B. (2016) The Concept of Integration as an Analytical Tool and as a Policy Concept, in Garcés-Mascareñas, B. \& Penninx, R, Integration Processes and Policies in Europe, IMISCOE Research Series, Springer International Publishing, pp. 11-29.

Piore, M.J. (1979) Birds of Passage: Migrant Labor in Industrial Societies, Cambridge, Cambridge University Press.

Poppelaars, C. \& Scholten, P. (2008) Two Worlds Apart. The Divergence of National and Local Immigrant Policies in the Netherlands, Administration \& Society, 40(4), pp. 335-357.

Regine, P. (2012) Limits of the Competition State? The Cultural Political Economy of European Labor Migration Policies, Critical Policy Studies, 6(4), pp. 379-401.

Ring, H. (1995) Refugees in Sweden: Inclusion and Exclusion in the Welfare State, in Miles, R. \& Thränhardt, D. (eds.), Migration and European Integration: The Dynamics of Inclusion and Exclusion, London: Pinter Publishers, pp. 159-176.

Ritchey, P.N. (1976) Explanations of Migration, Annual Review of Sociology, 2, pp. 363-404. 
Ruhs, M. (2013) The Price of Rights: Regulating International Labor Migration, Princeton \& Oxford, Princeton University Press.

Ruhs, M. (2015) Is Unrestricted Immigration Compatible with Inclusive Welfare States? The (Un) Sustainability of EU Exceptionalism, COMPAS Working Paper No. 125, University of Oxford.

Sager, A. (2016) Methodological Nationalism, Migration and Political Theory, Political Studies, 64(1), pp. 42-59.

Samers, M. (2010) Migration, London, Routledge.

Sassen, S. (1998) The De Facto Transnationalizing of Immigration Policy, in Joppke, C. (ed.), Challenge to the Nation-State, Oxford, Oxford University Press, pp. 49-85.

Schierup, C. \& Ålund, A. (2011) The End of Swedish Exceptionalism? Citizenship, Neoliberalism and the Politics of Exclusion, Race and Class, 53(1), pp. 45-64.

Scholten, P. (2013) Agenda Dynamics and the Multilevel Governance of Migrant Integration: The Case of Dutch Migrant Integration Policies, Policy Sciences, 46(3), pp. 217-236.

Scholten, P. \& Penninx, R. (2016) The Multilevel Governance of Migration and Integration, in Garcés-Mascareñas, B. \& Penninx, R. (eds.), Integration Processes and Policies in Europe, IMISCOE Research Series, Springer International Publishing, pp. 91-108.

Sciortino, G. (2000) Toward a Political Sociology of Entry Policies: Conceptual Problems and Theoretical Proposals, Journal of Ethnic and Migration Studies, 26(2), pp. 213-228.

Sellers, J.M. \& Lindtsröm, A. (2007) Decentralization, Local Government, and the Welfare State, Governance: An International Journal of Policy, Administration, and Institutions, 20(4), pp. 609-632.

Sjaastad, L.A. (1962) The Costs and Returns of Human Migration, The Journal of Political Economy, 70(5), pp. 80-93.

Soininen, M. (1999) The 'Swedish Model' as an Institutional Framework for Immigrant Membership Rights, Journal of Ethnic and Migration Studies, 25(4), pp. 685-702.

Somerville, W. (2013) The Politics and Policy of Skilled Economic Immigration Under New Labour, 1997-2010, in Triadafilopoulos, T. (ed.), Wanted and Welcome? Policies for Highly Skilled Immigrants in Comparative Perspective, New York, Springer, pp. 257-271.

Soysal, Y.N. (1994) Limits of Citizenship: Migrants and Postnational Membership in Europe, Chicago \& London, University of Chicago Press.

Stark, O. (1991) The Migration of Labor, Cambridge \& Oxford, Blackwell. 
Swedish Government (2011) Framework Agreement between the Government and the Green Party Concerning Migration Policy, Written agreement from 3 March 2011, Stockholm: Swedish Government.

Södergran, L. (2000) Svensk Invandrar-och Integrationspolitik: En Fråga om Jämlikhet, Demokrati och Mänskliga Rättigheter, Umeå, Umeå University.

Thielemann, E.R. (2004) Why Asylum Policy Harmonization Undermines Refugee Burden-Sharing. European Journal of Migration and Law, 6, pp. $47-64$.

Thielemann, E.R. (2012) How Effective are National and EU Policies in the Area of Forced Migration? Refugee Survey Quarterly, 31(4), pp. 21-37.

Todaro, M.P. (1976) Internal Migration in Developing Countries: A Review of Theory, Evidence, Methodology and Research, Geneva, International Labour Office.

Toshkov, D.D. (2014) The Dynamic Relationship Between Asylum Applications and Recognition Rates in Europe (1987-2010), European Union Politics, Early view.

UNHCR (2012) Asylum Levels and Trends in Industrialized Countries, 2011: Statistical Overview of Asylum Applications Lodged in Europe and Selected Non-European Countries, Geneva, UNHCR.

United Nations (2016) International Migration Report 2015: Highlights, New York, United Nations.

Van den Broek, D., Harvey, W.S. \& Groutsis, D. (2016) Commercial Migration Intermediaries and the Segmentation of Skilled Migrant Employment, Work, Employment \& Society, 30(3), pp. 523-534.

Vogiazides, L., \& Hedberg, C. (2013) Trafficking for Forced Labour and Labour Exploitation in Sweden: Examples from the Restaurant and the Berry Industries, in Ollus, N., Jokinen, A., \& Joutsen, M. (eds.), Exploitation of Migrant Workers in Finland, Sweden, Estonia and Lithuania: Uncovering the Links Between Recruitment, Irregular Employment Practices and Labour Trafficking, Helsinki, European Institute for Crime Prevention and Control, pp. 171-237.

Wallerstein, I.M. (1983) Historical Capitalism. London, Verso.

Wiesbrock, A. (2011) The Integration of Immigrants in Sweden: A Model for the European Union? International Migration, 49(4): pp. 48-66.

Wimmer, A. \& Glick Schiller, N. (2002) Methodological Nationalism and Beyond: Nation-State Building, Migration and the Social Sciences, Global Networks, 2(4), pp. 301-334.

Wimmer, A., \& Glick Schiller, N. (2003) Methodological Nationalism, the Social Sciences, and the Study of Migration: An Essay in Historical Epistemology, International Migration Review, 37(3), pp. 576-610. 
Wingborg, M. \& Fredén, J. (2011) Mors Lilla Olle II: Hur Gick Det För Blåbärsplockarna Sommaren 2011, Swedwatch report 43, Viveka Risberg.

Wingborg, M. (2014) Villkoren för Utländska Bärplockare Säsongen 2014, Stockholm, Arena idé.

Woolfson, C., Thörnqvist, C. \& Herzfeld Olsson, P. (2011) Forced Labour in Sweden? Case of Migrant Berry Pickers: A Report to the Council of Baltic Sea States Task Force on Trafficking in Human Beings: Forced Labour Exploitation and Counter Trafficking in the Baltic Sea Region, Linköping, Linköping University Electronic Press.

Wright, C.F. (2015) Why Do States Adopt Liberal Immigration Policies? The Policymaking Dynamics of Skilled Visa Reform in Australia, Journal of Ethnic and Migration Studies, 41(2), pp. 306-328.

Zolberg, A.R. (1981) International Migrations in Political Perspective, in Kritz, M.M, Keely, C.B. \& Tomasi, S.M. (eds.), Global Trends in Migration: Theory and Research on International Population Movements, New York, Center for Migration Studies, pp. 3-27.

Zolberg, A.R. (1989) The Next Waves: Migration Theory for a Changing World, International Migration Review, 23(3), pp. 403-430.

Zolberg, A.R. (1999) Matters of State: Theorizing Immigration Policy, in Hirschman, C., Kasinitz, P. \& DeWind, J. (eds.), The Handbook of International Migration: The American Experience, New York, Russell Sage Foundation, pp. 71-93. 
PAPERS I - IV 
I 



\section{of Migration Research}

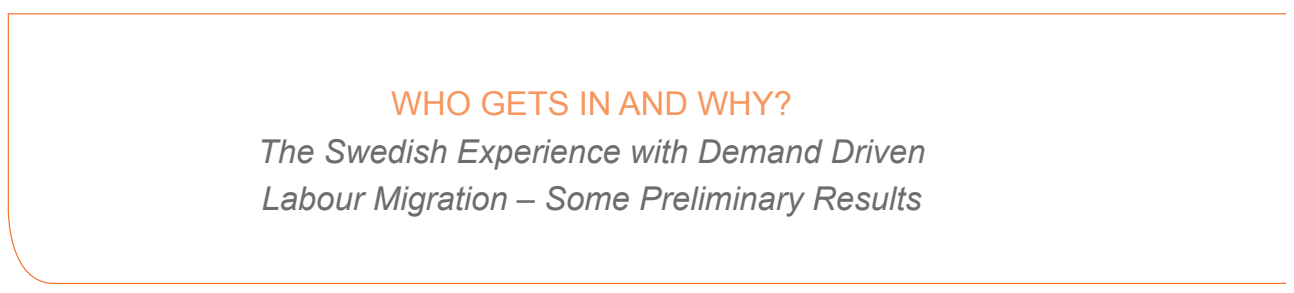

\section{Abstract}

In 2008, the Swedish government liberalised the labour migration policy to a demand driven model without labour market tests. This article analyses the effects of the policy change on the labour migration inflow. The migrants consist of three major categories including those moving to: skilled jobs as compute specialists and engineers, low-skilled jobs in the private service sector and seasonal work in the berry picking industry. The article shows that the new seasonal work in the bery picking industy. The atticle shows that the new model has produced a labour migration inflow that is better explained by the access of employers and migrants to transnational networks rather than actual demand for labour

Keywords

Labour migration • labour migration policy $\cdot$ migration policy $\cdot$ Sweden

Received 18 October 2013; Accepted 10 July 2014

\section{Introduction}

In the midst of the ongoing financial crisis in 2008, the Swedish government decided to liberalise the labour migration policy for persons outside European Union (EU) to a demand driven mode that is one of the industrialised world's most liberal (OECD 2011). The reform meant that the labour market test was abolished and the selection of labour migration was handed over to individual employers. The aim of the reform was to facilitate recruitment of labour from third countries, i.e. non-EU member countries. (Bill 2007/2008: 147). In the bill, there was no explicit explanation as to why it is importan to facilitate labour migration, but the government elaborated on the topic in their information material. In the short term, it is supposed to ease labour shortage in specific occupations and sectors and in the long term be one of the responses to the demographic challenges of an ageing population (Government Offices of Sweden 2008). This message is still communicated by the government. One recent example is the statement by the migration minister Tobias Billström at the 2013 UN Commission on population and development where he said that "the main driving-force for the Swedish reform was the recognition that there are labour shortages in Sweden that will not be filled solely by people living in Sweden or in other EEA countries". The Swedish policy direction goes against the general response in European countries following the economic crisis in 2008 that made it more difficult to immigrate as a labour migrant (Koehler et al. 2010; Kuptsch 2012). It also contrasts a longer European trend towards a more selective labour migration policy where states have

\section{Henrik Emilsson*}

\section{Malmö University, Sweden}

tried to attract high-skilled workers and restrict low-skilled workers to temporary migration programmes with less access to rights (Ruhs 2011; De Somer 2012). In addition, it also contradicts several of the dominant theories on how countries are designing their migration policy where Nordic welfare states are supposed to limit labour migration to high-skilled workers (Meyers 2000; Menz 2008).

Sweden is clearly a deviant case in their choice of policy and therefore a particularly interesting case to study. The principal aim of the paper is to analyse the effects of the new policy on the labour migration inflow and offer some explanations why we see these effects. In the article I discuss about these effects as policy outcomes. Thus, the specific focus of this article is to answer: What are the policy outcomes of the new demand driven labour migration model? How can the policy outcomes be explained?

Several sources of information are used to answer the questions. Statistical information about labour migration flows was collected from the Migration Board. ${ }^{2}$ Reports and research about the Swedish labour migration policy and its effects are analysed. To complement the written material about the subject, 14 interviews were conducted with key stakeholders, such as civil servants, researchers, trade unions and employer organisations. The interviews were conducted by Karin Magnusson in October 2012 and are listed after the references. Any direct reference to the interviews in the text is marked in parentheses using abbreviations.

The paper begins by situating the research in the debate about migration and the state in general and more specifically about the role of the state when selecting labour migrants. Then, the 
Swedish labour migration model is described. As a next step, the migration inflow is described and analysed in relation to the current and future labour market needs. I conclude by analysing the policy outcomes.

\section{The role of the state in migration theory}

I have chosen to frame the article in the academic debate about the role of the state in migration theory. Prominent scholars such as Hollifield (2008) and Massey (1999) have noted that migration theory has been very little interested in the role of the state in determining migration movements and migration patterns. Government restrictions are mainly dealt with as distortions of the rational market in economic theories of migration (Castles \& Miller 2009). But borders and migration policy regulations must be taken into account to understand migration patterns and the fact that few persons migrate despite economic disparities and immigrant networks (Zolberg 1981, 1989). The right of a state to control entry and exit of persons from its territory is an undisputed principle in international law (Shaw 1997). The state should, thus, have a very strong power to influence migration flows.

Research and theories about the role of the state in migration theory deal with two separate, but interlinked, research questions. The first is about policy output, i.e. the formulation of migration policies. The second is about policy outcomes, i.e. the results of these policies (Hollifield 1986). Some researchers mix the two in one general question of a "control gap" paradox, originally developed by Cornelius \& Tsuda (2004: 3). They argued that the gap between the goals of national immigration policy and the actual results of the policies is wide and growing wider. However, the control gap paradox is contested. For example, Bonjour (2011) makes strong arguments in her study on Dutch family migration policy that the state has the capacity to regulate migration flows and stocks. Zolberg (1981) even argued that the independent effects of state policies for controlling entry and exit can be measured. Research specifically on labour migration has shown that state policies have an effect on immigration trends and employer labour utilisation strategies (Bach 2010; Regine 2011). At the same time, there are many examples why migration policies tend to fail and produce different immigration flows than are expected and wanted (Castles 2004). Policy gaps can be caused by either unintended consequences or inadequate implementation of policy. The policy itself can be flawed or unable to counteract the macro-structural forces that facilitate migration. Differentials in wage levels and job availability between countries propel migrants across borders, regardless of the strategy of nation states. Migrant social networks also tend to spur further migration. In addition, transnational labour brokers and migrant smugglers facilitate access across borders and to the labour markets of the receiving countries. A migration industry has developed helping migrants with illegal and legal services. There has also been an expansion of rights for migrants (Hollifield 2008). Migration theories are, in general, very convincing in their arguments that it is difficult for states to control migration. This is especially true for theories on a meso-level that emphasise the importance of networks and social capital in structuring patterns of migration (Faist 2000). Networks create linkages between sender and recipient countries that reduce the risks when moving from one country to another and sustain patterns of migration over time through "cumulative causation" (Massey 1990). Some conceptualise these kinds of migration networks as systems linking the sending and receiving areas (Zlotnik 1992)

\section{Selecting labour migrants}

To simplify, states often choose to go with one of the two main models for managing labour migration, namely, supply driven model or demand driven model. Hybrid models are becoming more common, but most policies take their departure from one of them (Papademitriou \& Sumption 2011; Chaloff \& Lemaitre 2009). In a supply driven model, the state admits migrants according to the skills and human capital of the individual, such as education level, work experience, language skills and age. Canada and Australia are usually mentioned as the prime examples of this kind of model, even if they combine it with demand driven temporary migration. In a demand driven model, it is the employers who choose what kind of migrants are needed. The new Swedish law is probably the purest example of this latter model.

There are expected pros and cons in both a supply driven and a demand driven labour migration model (Papademitriou \& Sumption 2011). The advantage of a supply driven model is that it creates clear and transparent rules on what kind of migrants a country wishes to attract, i.e. the type and level of human capital. The model also gives a clear signal to the public that immigration is regulated and controlled. The aim is to attract highly educated and flexible migrants who take care of medium and long term labour market needs. The downside is that labour migrants come to the country without work, and there is no guarantee that the persons' knowledge and skills are wanted by employers. In a demand driven model, the migrant has a job upon arrival and the country can avoid initial periods of unemployment. The downside is that the work permit is tied to a specific employer that increases the risk of employers manipulating the system and hire migrants with lower wages and worse employment conditions. Also, the work permit is often temporary in a demand driven system, which can lead to irregular situations if the immigrants lose their jobs. What kind of unintended effects a labour migration model produces depend to a large extent on how flexible the labour market is (Boswell \& Geddes 2011). In Sweden where there are high minimum wages and relatively generous employment benefits, there is less scope for immigrants to push down wages or displace native workers. However, employers may have incentives to bypass these costs by hiring immigrants with worse salaries and employment conditions than what is allowed.

The expected advantages and disadvantages of a demand driven model were also reflected in the debate ahead of the 2008 decision in parliament. The most controversial issue was the abolition of the labour market test (Murhem \& Dahlkvist 2011). The unions criticised the proposal, arguing that it is unreasonable to give employers such a large influence based on distrust that employers would only recruit labour to sectors and occupations with labour shortages. The largest business federation, Confederation of Swedish Enterprises, supported the abolition of the labour market test, but was critical that the work permit would be tied to a specific employer. There was also criticism from trade unions about the possibility of getting work permits from inside Sweden that, according to them, could create a parallel labour migration system where asylum and labour migration flows become mixed up.

\section{Selecting labour migrants: the Swedish labour migration model}

The 2008 law was a clear breach of an almost 40-year long period of state controlled labour migration. The biggest change was that the 
Table 1. Work permits granted during 2005-2012*

\begin{tabular}{|c|c|c|c|c|c|c|c|c|}
\hline & $\mathbf{2 0 0 5}$ & $\mathbf{2 0 0 6}$ & $\mathbf{2 0 0 7}$ & $\mathbf{2 0 0 8}$ & $\mathbf{2 0 0 9}$ & $\mathbf{2 0 1 0}$ & $\mathbf{2 0 1 1}$ & $\mathbf{2 0 1 2}$ \\
\hline Total labour migration & 3631 & 3637 & 7187 & 11255 & 14905 & 14001 & 15158 & 17011 \\
\hline Seasonal/agriculture & 496 & 70 & 2358 & 3747 & 7200 & 4508 & 2821 & 5708 \\
\hline Excluding agricultural & 3135 & 3567 & 4829 & 7508 & 7705 & 9493 & 12337 & 11303 \\
\hline
\end{tabular}

Source: Migration Board

* The numbers do not exactly corresponds to Table 2; the datasource is different.

Table 2. Work permits from 1 January 2009 to 31 December 2012

\begin{tabular}{|c|c|c|c|c|c|}
\hline & $\mathbf{2 0 0 9}$ & $\mathbf{2 0 1 0}$ & $\mathbf{2 0 1 1}$ & $\mathbf{2 0 1 2}$ & $\mathbf{2 0 0 9 - 2 0 1 2}$ \\
\hline Seasonal workers & 7200 & $\mathbf{4} 508$ & 2821 & 5708 & 20237 \\
\hline High-skilled jobs & 5345 & 6015 & 7404 & 7576 & 26340 \\
\hline Low-skilled jobs & 1929 & 3088 & 4497 & 3259 & 12773 \\
\hline $\begin{array}{c}\text { Total labour } \\
\text { migration }\end{array}$ & $\begin{array}{c}14 \\
474\end{array}$ & $\begin{array}{c}13 \\
611\end{array}$ & $\begin{array}{c}14 \\
722\end{array}$ & $\begin{array}{c}16 \\
543\end{array}$ & 59350 \\
\hline
\end{tabular}

Source: Migration Board

so-called labour market test was abolished. Now it is the employers not state agencies and unions, who decide the need for labou and from which part of the world they wish to recruit. There are no restrictions with regard to skills, occupational categories or sectors and there are no quantitative restrictions in the form of quotas. The reform also meant that the specific rules on seasonal work were abolished. The only condition to get a work permit is an offer of employment with a wage one can live on $^{3}$ and that the level of pay is in line with applicable collective agreements and general insurance conditions. ${ }^{4}$ The trade union concerned is given the opportunity to express its views on the terms in the employment contracts but does not have a veto.

Work and residence permits must normally be arranged prior to leaving one's country of origin. In certain cases, a residence and work permit may be granted from Sweden. The precondition is that the application is done during the visa-free period ( 90 days) or before the entry visa expires and the employment relates to work where there is a labour demand. ${ }^{5}$ Visiting students who have completed studies for one semester are entitled to apply for a work and residence permit from within Sweden. Asylum seekers whose asylum application has been rejected may also be granted a permit if they have worked fo six months with a one-year offer of continued work.

$A$ residence and work permit can be granted for no more than two years and can be extended up to a maximum of four years. A permanent residence permit is granted if he or she has worked for an aggregate period of four years during the past five years. The permit is linked to an occupation and employer for two years and then, in the event of a subsequent extension, to an occupation for a further two years. There is some degree of flexibility in the system. If an individual would like to change employer during the first term, he/she can apply for a new work permit from Sweden. If a person is losing her job, she has three months to find a new one before the residence permit is revoked.
The principle of Community preference applies ${ }^{6}$ In practice, this obligation is fulfilled if the employer advertises in the European Job Mobility Portal (EURES) for 10 days, but there are no serious checks if an employer has made the job offer public within the European Union/European Economic Area. The announcement is just a formality, and an employer can choose to recruit from outside EU even if there are available unemployed workers within Sweden and EU (Quirico 2012).

A labour migrant basically enjoys the same rights as other residents when working and living in Sweden. Family members are entitled to accompany the employee from day one and they get a work permit regardless of whether they have a job offer when leaving their country of origin.

\section{Labour migration to Sweden from non-EU countries $^{7}$}

This section studies the policy outcomes of the new demand driven labour migration model by analysing the statistical evidence of the labour migration flows to Sweden after the 2008 law. As can be seen from Table 1, labour migration to Sweden has increased after the new law came into force. But it is important to note that the number of migrant workers also increased rapidly in the years that preceded the law.

Looking at the labour migration after the new rules were introduced, the number of third country nationals coming to Sweden has ranged between 13,600 and 16,600 . The majority, close to 80 per cent, are male. After a downturn in 2010, the numbers increased again in 2011 and 2012, despite the fact that the economic recession took a turn for the worse in 2012. If we exclude the seasonal workers, the picture is somewhat different. From this perspective, Sweden experienced a growth of labour migration up until 2011, and a slight decline of about 1,000 persons in 2012. A distinct break in the trend as a result of the new opportunities is not visible; however, it is quite clear that the numbers have stabilised on a higher level than before, especially if seasonal workers are excluded.

By looking at the area of work categories in Table 3 we get a good overview of the general pattern of labour migration, characterised by migration to both low- and high-skilled jobs. In Table 2, the categories have been compiled into three major categories: skilled, low skilled and seasonal. ${ }^{8}$ While the number of high-skilled workers have increased during the entire period, from 5,300 in 2009 to 7,600 in 2012, the low-skilled workers increased from 1,900 in 2009 to 4,900 in 2011, and then fell to about 3,300 in 2012.

The special rules for students and asylum seekers have allowed for about 3,100 foreign students to receive work permits until the

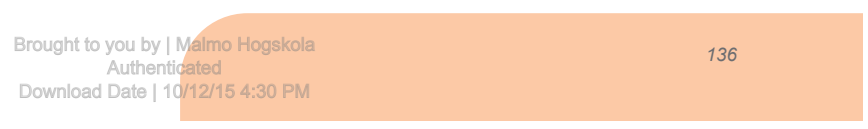




\section{Nordic Journa}

\section{of Migration Research}

Table 3. Work permits granted by area of work and occupational group, 2009-2012, and current balance of workers in occupational groups

\begin{tabular}{|c|c|c|c|c|c|}
\hline & 2009 & 2010 & 2011 & 2012 & \\
\hline Total, of which & 14481 & 13612 & 14722 & 16543 & \\
\hline Refused asylum seekers & 425 & 465 & 303 & 188 & \\
\hline Students & 405 & 453 & 1053 & 1203 & \\
\hline Total, excluding Agricultural, fishery and related labourers ${ }^{\star \star}$ & 7281 & 9104 & 11901 & 10835 & \\
\hline \multicolumn{6}{|l|}{ Area of work } \\
\hline Elementary occupations & 7859 & 5712 & 4784 & 7166 & \\
\hline Professionals & 3232 & 3257 & 4052 & 4539 & \\
\hline Service workers and shop sales workers & 1032 & 1512 & 2037 & 1392 & \\
\hline Craft and related trades workers & 576 & 959 & 1322 & 1126 & \\
\hline Technicians and associate professionals & 1023 & 1142 & 1117 & 1311 & \\
\hline Skilled agricultural and fishery workers & 300 & 391 & 536 & 376 & \\
\hline Legislators, senior officials and managers & 206 & 264 & 375 & 219 & \\
\hline Plant and machine operators and assemblers & 128 & 172 & 253 & 186 & \\
\hline Clerks & 110 & 200 & 244 & 223 & \\
\hline Armed forces & 8 & 2 & 2 & 5 & \\
\hline Occupational group (most common) & & & & & Shortage/Surplus \\
\hline Agricultural, fishery and related labourers & 7200 & 4508 & 2821 & 5708 & shortage \\
\hline Computing professionals & 2202 & 2208 & 2795 & 3259 & shortage \\
\hline Housekeeping and restaurant services workers & 769 & 1049 & 1323 & 861 & surplus \\
\hline Helpers in restaurants & 257 & 548 & 796 & 570 & surplus \\
\hline Architects, engineers and related professionals & 541 & 525 & 630 & 558 & shortage \\
\hline Helpers and cleaners & 295 & 487 & 798 & 553 & surplus \\
\hline Physical and engineering science technicians & 481 & 332 & 338 & 412 & shortage \\
\hline Building frame and related trades workers & 191 & 226 & 362 & 329 & shortage \\
\hline Personal care and related workers & 132 & 210 & 250 & 257 & surplus \\
\hline Food processing and related trades workers & 130 & 330 & 386 & 251 & surplus \\
\hline Business professionals & 170 & 205 & 240 & 236 & no forecast \\
\hline Doorkeepers, newspaper and package deliverers and related & 67 & 100 & 177 & 192 & surplus \\
\hline
\end{tabular}

Source: Migration Board and for estimations of occupational shortage/surplus, Employment Service (2012b)

*Agricultural, fishery and related labourers are almost all seasonal workers picking berries. Their number changes a lot between different years. Excluding them can give a better picture of labour migration in general 
end of 2012. The number more than doubled in 2011 when over 1,000 students were granted a work permit. During the same time period, close to 1,400 former asylum seekers was granted work permit.

In terms of the labour market as a whole, labour immigration remains marginal except in a few occupations such as compute professionals and berry pickers (see Table 3 ). Computer professionals have been the second largest group during the entire period with a steady increase since 2009. Berry pickers, who account for nearly all of the agricultural, fishery and related workers, have been the largest group and their number has fluctuated a lot, from 7,200 in 2009 to 2,800 in 2011. Other occupations that have attracted many migrants are low-skilled jobs in the service sector, such as housekeeping and restaurant services workers, helpers in restaurants and helpers and cleaners.

In Table 3, the inflow of labour migrants is compared with the estimated demand from the Employment Service (2012b). We find that many of the migrants came to work in occupations with demand for labour. This especially applies to computing professionals, but also engineers and technicians. At the same time, many labour migrants are in occupations where there is a big surplus of available workers. This is, for example, true for cleaners and restaurants workers. Since 2009 up until 2012, about 12,800 persons were granted work permits in low-skilled jobs in sectors and occupations without any obvious need for migrant workers, which represents about 22 pe cent of the work permits. ${ }^{9}$ This can add to the mismatch between demand and supply in the Swedish labour market, where the major issue is that the group with low educational background is growing while the number of low-skilled jobs is shrinking (The Employment Service 2012a). At the same time, there are several occupation in need of workers, both in the short and long run, where there is very limited labour migration from third countries. The most obvious examples are high-skilled occupations within health care, such as nurses and doctors, where there are expected short- and long-term labour shortages (Statistics Sweden 2012; Employment Service 2010).

To conclude, the labour migration inflow to Sweden is dominated by a few areas of work (elementary occupations and professionals and occupations (agricultural workers and computing professionals) that are in large part characterised by labour shortages. At the same time, many come to work in low-skilled occupations with current and future labour surplus.

\section{Explaining labour migration to Sweden}

Through the introduction of the new law, individuals from countries outside EU got, in principle, the same opportunities to obtain work in Sweden as people within EU. But possibilities do not always transfer into reality. The Swedish policy does not include any component that matches potential labour migrants with Swedish employers. There are no recruitment offices for labour migration set up by authorities outside of Sweden and no special programmes for the recruitmen of high-skilled workers. Moreover, the state has not entered into any bilateral agreements and Sweden is one of the few developed countries that do not cooperate with the International Organization for Migration (IOM) when it comes to labour migration issues (IOM 2012). There is little room for such arrangements in a system based on individual employers' labour demand. The hands-off approach does probably explain why some groups of employers recruit remarkably few labour migrants from third countries.
A demand driven labour migration system, such as the Swedish, assumes that the employment match between employers and the employee happens without any previous meeting between the two counterparts. In this context, access to labour market information for both employers and prospective migrants is the key if international migration is to play a role in responding to labour and skills shortages. The web portal workinginsweden.se, which is considered as good practice by the OECD (2012), has been set up to advertise the possibilities for work and communicate the rules to potential labour migrants. It contains information in seven languages about the regulations and procedures of obtaining a work permit together with facts about living conditions in Sweden. The portal has a link to EURES, which is automatically updated with job ads from the Employment Service. The problem is that those job advertisements are not aimed at third country nationals. Most advertisements are published in Swedish with a Swedish audience in mind (interview with PES 1). Even if an employer finds a potential employee, there is still an issue of asymmetric information (Katz \& Stark 1987). Employers have a hard time to know the productivity level of a potential employee when labour markets are in two different countries. As a result, few employers without established networks recruit migrant workers (Employment Service 2012c). One option could be to use recruitment agencies. However, Swedish and international recruitment companies do not seem to be very active in this market (Joona \& Wadensjö 2011).

According to the informants, waiting times is another issue that hinders employers from hiring workers from third countries, even though Sweden treats applications for work permits quickly and charges relatively low fees compared with other countries (OECD 2011). This is particularly true for companies looking to recruit workers in occupations with high international competition, such as information technology (IT). The waiting times for work permits are also troublesome for employers wanting to recruit third country workers to fill temporary needs in the labour market.

Another large obstacle is that many professions do not have a labour market that is truly international, as training, accreditation, ethics and standards continue to be managed at the national level (Iredale 2001). This is one major reason for the health care sector to only employ a handful of nurses and doctors from third countries every year. Receiving the validation for these professions is a long and complicated procedure, which can take years even for workers from EU countries (interview with PES 2). Validation also requires knowledge in the Swedish language. A demand driven system, like the Swedish one, is ill suited for recruiting third country workers in occupations where third country workers are not instantly job-ready. To be able to recruit doctors and nurses, the employer needs to se up extensive programmes for pre-departure training to get them jobready before a work permit can be granted. Given this, it is easier to recruit within Europe, especially since there has been some harmonisation of rules (Petersson 2012).

A potential obstacle that is surprisingly mentioned little in the interviews with the stakeholders is the language issue. Even in an international sector such as the IT-businesses, Swedish language skills seem very important. According to the IT and telecom companies' survey for member companies, 70 per cent of the employers require good Swedish language skills when recruiting. Insufficient language skills have also been an obstacle for recruitment of internationa students at Swedish universities since most of them do not speak Swedish (interview with IT). Chaloff \& Lemaitre (2009) even argue that countries with few native speakers outside their borders are unsuitable for a demand driven labour migration system as language

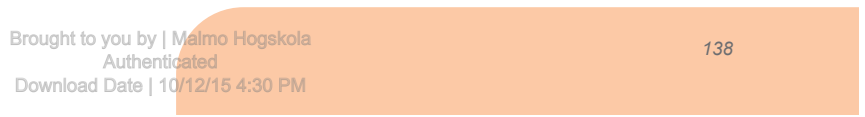


Table 4. Overview of the main recruitment channels for the three main labour migration flows

\begin{tabular}{|c|c|c|}
\hline Type of work & Small and medium sized employers & Large employers \\
\hline Skilled & Informal/personal contacts & Intra-company transfers,informal/personal contacts \\
\hline Low-skilled & Social network, brokers/agents & \\
\hline Seasonal & \multicolumn{2}{|c|}{ Foreign staffing companies, often involving the same workers every year } \\
\hline
\end{tabular}

barriers makes it difficult to hire someone directly into a job. For such countries, they propose a supply driven system with significant investments in language teaching for new arrivals.

This section has shown that there are several obstacles to recruit foreign workers in a demand driven labour migration model like the Swedish one. In fact, some labour shortages may only be met if the state intervenes in the matching process between foreign workers and Swedish employees and/or by complementing the model with supply driven elements.

\section{Analysis of the three main flows of labour migrants}

As earlier research has noted, there is a need for more information about how the recruitment of labour migrants occurs, who is staying or returning and the conditions in the labour market for different categories of labour migrants in Sweden (Joona \& Wadensjö 2011). This paper contributes to lowering the knowledge gap by studying the three dominating labour migration flows in more detail.

\subsection{High skilled}

The overwhelming majority of the high-skilled migrants are IT professionals from India and China who are recruited by large, multinational companies in sectors that have a great demand for skilled workers (Employment Service 2012c). Occupations in the IT industry do not have professional accreditation requirements, and therefore the potential for international mobility and transferability of skills is great. Also, the technical basis of the occupations makes issues of cultural and social aspects less important (Iredale 2001). There are some indications that the work permits for high-skilled workers in shortage occupations are disproportionately for shortterm stays (OECD 2011). In skilled occupations, for example IT, it is common with short work permits covering temporary needs, such as temporary development projects, education of staff from subsidiary corporations or to facilitate the communication with the organisation's units in other parts of the world (Oxford Research 2009). A majority of the work permits seems to be intra-corporate transfers, made within the company or from subsidiaries (Joona \& Wadensjö 2011; Quirico 2012). Intra-corporate transfers are easily facilitated in large corporations that have been certified by the Migration Board and can go through the work permit application process very fast. Large companies also have an advantage thanks to their international reputation (PES 1). They are able to use their own websites to advertise work opportunities and employees might get in touch with them directly (interviews with $\mathrm{Si}, \mathrm{SCF}$ ). They also have a large network and can use current employees to find more people with the same expertise (interviews with CSE, TS). From what is known, the inflow of high-skilled migrants can best be understood as part of a circular migration regime in highly competitive sectors of the globalised economy. Based on the country's position in the immigration market (Borjas 1999), the workers tends to originate from countries not belonging to the richest part of the world to whom Swedish companies are able to offer attractive conditions and competitive wages in the global race for talents (Kuvik 2013).

\subsection{Low skilled}

While high-skilled migrants usually are transferred within large companies or are recruited through professional networks, low-skilled migrants have to rely on informal contacts and personal connections. A study of Iraqi labour migrants to Sweden showed that they used contacts and social networks, often relatives, to get a job offer (Pelling \& Nordlund 2012). To get in touch with Swedish employers from Iraq without personal connections was unrealistic according to the interviewees. If the migrants do not have personal connections, they might have to pay companies in their countries of origin to gain information and a work offer. A similar type of information service exists in Sweden where asylum seekers who have been denied asylum can pay specialised lawyers to get information about rules and obtain job offers (interview with GC). The large majority of the low-skilled migrants are from countries that previously generated refugees to Sweden. For many, the possibility to get a work permit is an alternative to being granted asylum. Of the 545 Iraqi citizens who obtained a work permit in Sweden in 2011, about 50 per cent of them had previously applied for asylum in Sweden (Jonsson 2012). ${ }^{10}$

Employers recruiting low-skilled labour migrants are often small sized companies owned by persons with foreign background, often from the Middle East. These employers represent around a third of all the granted work permits in Sweden and operate in sectors such as restaurant and cleaning businesses that before 2008 had limited opportunities to recruit workers in third countries (Employment Service 2012c). According to OECD (2011), it is a cause for concern that so many labour migrants are going into non-shortage elementary occupations since there is no obvious need for them in the labour market. Labour migration to low-skilled jobs in the private service sector can be seen as an unintended effect of the demand driven labour migration model. Another unintended effect is the many cases of abuse and exploitation of migrant workers by employers. Follow-up studies from trade unions reveal alarming conditions for migrant workers in the low-skilled service sector (HRF 2012; TCO 2012; Swedish Trade Union Confederation 2013). The abuse can be divided into two types: situations where the employer has not met the requirements of wages and working conditions, and situations that can be described as illegal trade with work permits (TCO 2012). In some cases, it is the individual employers who want to earn money by selling work permits. But there are also cases where friends and 


\section{of Migration Research}

relatives want to help a friend to come to Sweden but cannot afford to hire anyone. The only way is then for the migrant workers to pay thei own salary (Pelling \& Nordlund 2012). Instead of reacting to a large demand, labour migrants to low-skilled occupations are responding to strong push factors in their homeland. They draw on resources from their social networks or pay actors in the migration industry to leave a country of origin where they do not see a future.

\subsection{Seasonal}

The third large category of labour migration to Sweden is seasonal workers. Almost all of them are berry pickers from Thailand. No other country had work permits for berry picking during the 2012 season. They are farmers from rural areas in north-east Thailand, and recruited by Thai recruitment companies and agencies. There are well-established networks among specific villages, Thai recruitment companies and Swedish berry picking companies. There are a few dominant staffing companies bringing workers to Sweden (Wingborg \& Fredén 2011). Norrskensbär, one of the largest wholesale companies, uses the same recruitment company every year in order to get berry pickers with experience of picking berries in Sweden. Estimates are that about 70-80 per cent of the pickers have been to Sweden before (interview with BP). Today, the Swedish berry picking industry is highly dependent on seasonal migran workers, who represent about 80 per cent of the employment in the industry (Wingborg \& Fredén 2011). This form of labour migration is probably best understood within a dual labour market framework (Piore 1979). There is a demand for labour that the domestic labou force is unwilling to supply considering the wage levels and working conditions. Migrants, on the other hand, view the jobs as a means to earn an income that by their home country standards appears satisfactory.

\section{Concluding discussion}

In 2008 Sweden liberalised the labour migration policy from countries outside EU to a demand driven model without labour market tests. The aim was to facilitate labour migration to ease labour shortage in specific occupations and sectors and in the long term be one of the responses to the demographic challenges of an ageing population. The principal aim of the paper is to analyse the effects of the policy on the labour migration inflow and offer some explanations why we see these effects. The ambition is to expand the knowledge on how labour migration models can affect patterns of migration.

The policy outcome of the new labour migration model is a modest but steadily growing inflow of migrant workers. The labour migrants can roughly be divided into three major categories: those moving to skilled jobs as computer specialists and engineers, to low-skilled jobs in the private service sector and to seasonal work in the berry picking industry. About 80 per cent work in occupations with need for labour. This especially applies to skilled jobs as computing professionals engineers and technicians but also seasonal workers in the berry picking industry. At the same time, about 20 per cent come to work in low-skilled jobs in the private service sector where there is a large surplus of available workers. In addition, some occupations with labour shortages recruit very few workers from outside EU.

The Swedish model for labour migration has produced unintended effects. There is clearly a gap between what the government said they wanted from the reform - to facilitate labou migration to shortage occupations - and the outcome. The relatively large inflows of workers to low-skilled occupations without labour shortages can be seen as an unintended effect, even if the rules allow for this category of workers. The other unintended effect is that employers in sectors without any obvious need to look for workers outside of Sweden hire third country nationals for lower wages and worse working conditions than what is legal in Sweden. The results therefore support the observation by Papademitiriou \& Sumption (2011) that demand driven labour migration models tend to be open for abuse and employer manipulation.

How can this result be explained? First, I want to stress the importance of networks to understand the migration flows. The new law significantly reduced the power of the state to control the migration flows and allowed for all types of labour migration. By liberalising, both market forces and kinship networks can play out more freely. I have shown that the three major flows of labour migrants to Sweden - high-skilled computer specialists and engineers, low-skilled workers in private service sector jobs and seasonal migrants picking berries - are to a large extent dependent of established transnational networks. If a company is without access to international networks, it limits the possibilities to recruit even if the regulatory framework is generous. Also, since the state has handed over the responsibility for matching to the market, there is no room for cooperation between origin and destination countries like international agreements, organised pre-departure training and educational programmes. This makes it difficult to recruit personnel for shortage occupations, such as doctors and nurses, which require training and supplementary education in order to work in Sweden.

Second, the policy outcome shows that we need to analyse and explain different inflows of labour migrants separately as they are a result of different driving forces. The inflow of high-skilled workers can best be understood as part of a circular migration regime in highly competitive sectors of the globalised economy. On the other hand, the large majority of the migrants to low-skilled jobs come to Sweden for the same reasons as humanitarian migrants, to escape difficult living conditions in their country of origin. The presence of seasonal labour migration, dominated by the berry picking industry where the domestic labour force is unwilling to work, is probably best understood within a dual labour market framework.

Henrik Emilsson is a PhD at the Malmö Institute for Studies of Migration, Diversity and Welfare (MIM) and Global Political Studies (GPS) at Malmö University. He is also working in the EU-7 research project UniteEurope on social media and integration in cities. His most recent publication is Emilsson, $\mathrm{H}$ (2014) Sweden, in Triandafyllidou, A \& Gropas, R (ed), European Immigration: A Sourcebook, Ashgate.

\section{Acknowledgements}

I thank the anonymous reviewers and the editors for excellent comments. I also want to thank Karin Magnusson who performed the interviews with the experts and stakeholders.

\section{Notes}

1 Statement on 24 April 2013 at the UN Commission on Population and Development. Agenda item 4, general debate "National experiences in population matters: new trends in migration: demographic aspects". EEA = European Economic Area.

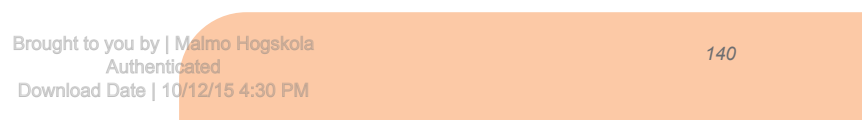


2 All statistics used in the tables are official statistics available from <http://www.migrationsverket.se> [Last accessed 07.03.2014].

3 The Migration Board has interpreted it as that the person must earn enough to not be entitled for income support from the municipality. In practice, this means a salary of at least 13,000 SEK (1,500 Euro) per month.

4 To understand the issue of labour migration and matching of employers and employees, it is important to understand the Swedish labour market model. Some characteristics are an active labour market policy, a high level of union organisation and coverage by collective agreements, strong statutory employment protection, generous unemployment benefits and the absence of direct government involvement. The collective agreement means that wages and general employment conditions are determined by the social partners, i.e. employers and employees, without interference by the state.

5 Regulated by the "shortage list" prepared by the Employment Service.

6 The principle of "Community preference" is defined by EU in the following terms: "Member States will consider requests for admission to their territories for the purpose of employment only where vacancies in a Member State cannot be filled by national and Community manpower or by non-Community manpower resident on a permanent basis in that Member State and already forming part of that Member State's regular labour market."
7 Certain categories of non-EU nationals do not require work permits, including postsecondary students and visiting researchers; certain high-skilled occupations, such as company representatives; visiting researchers or teachers in higher education; performers, technicians, and other tour personnel; and specialists temporary employed by a multinational corporation.

88 Skilled: Professionals, crafts and related trades workers, technicians and associate professionals, skilled agricultural and fishery workers, legislators, senior officials and managers and Armed forces. Low-skilled: Elementary occupations (excluding agricultural, fishery and related labourers who are almost all seasonal workers), service workers and shop sales workers, plant and machine operators and assemblers and clerks. Seasonal: Agricultural, fishery and related labourers.

9 The Employment Service produces occupational forecasts twice a year. A "shortage index" is used to quantify recruitment needs and identify the occupations where there is a shortage or surplus of applicants.

10 Only a few of them had "changed track" during the asylum process. Most of them were failed asylum seekers, who either had returned to their home country or had lived as undocumented migrants in Sweden, who later were offered a job. In these cases, it is necessary to apply for a work permit from abroad.

References

Andersson Joona, P \& Wadensjö, E 2011, Rekrytering av utländsk arbetskraft: Invandrares arbetsmiljö och anknytning till arbetsmarknaden i Sverige, Rapport 2011:1, Stockholms universitets Linnécentrum för Integrationsstudier (SULCIS), Stockholms University

Bach, S 2010, 'Managed migration? Nurse recruitment and the consequences of state policy', Industrial Relations Journal, Vol. 41 , no. 3, pp. 249-266, DOI: 10.1111/j.1468-2338.2010.00567.x

Bill 2007/2008:147, Nya regler för arbetskraftsinvandring, Justitiedepartementet, Available from: < http://www.regeringen. se>. [Last accessed 10.3.2014].

Bonjour, S 2011, 'The Power and Morals of Policy Makers: Reassessing the Control Gap Debate', International Migration Review, Vol. 45, no. 1, pp. 89-122, DOI: 10.1111/j.17477379.2010.00840.x

Borjas, G J 1999, 'The economic analysis of immigration' in Handbook of Labor Economics, ed OC Ashenfelter \& D Card, Elsevier, Vol. 3, pp. $1697-1760$

Boswell, C \& Geddes, A 2011, Migration and mobility in the European Union, Palgrave Macmillan, New York.

Castles, S 2004, 'Why migration policies fail', Ethnic and Racial Studies, Vol. 27: no. 2, pp. 205-227, DOI: 10.1080/0141987042000177306

Castles, S \& Miller, MJ 2009, The Age of Migration: International Population Movements in the Modern World, 4th edition, Basingstoke and New York: Palgrave Macmillan and Guilford

Chaloff, J \& Lemaitre, G 2009, Managing Highly-Skilled Labour Migration: A Comparative Analysis of Migration Policies and Challenges in OECD Countries, OECD Social, Employment and Migration Working Papers No.79, OECD Publishing, DOI: $10.1787 / 225505346577$

Cornelius, WA \& Tsuda, T 2004, 'Controlling immigration: the limits of government intervention' in Controlling immigration: A global perspective, second edition, ed WA Cornelius, T Tsuda, PL Martin \& JF Hollifield, Stanford University Press, Stanford, California, pp. 3-48

De Somer, M 2012 Trends and Gaps in the Academic Literature on EU Labour Migration Policies, CEPS Paper in Liberty and Security in Europe No. 50, Centre for European Policy Studies

Employment Service 2010, Var finns jobben: Bedömning för 2010 och en långsiktig utblick, Available from: < http://www. arbetsformedlingen.se>. [Last accessed 24.9.2013].

Employment Service 2012a, Arbetsmarknadsutsikterna våren 2012 Prognos för arbetsmarknaden 2012-2013, Available from: < $\mathrm{http}: / / \mathrm{www}$.arbetsformedlingen.se>. [Last accessed 24.9.2013].

Employment Service 2012b, Var finns jobben? Bedömning för 2012 och första halvåret 2013, Available from: < http://www. arbetsformedlingen.se>. [Last accessed 24.9.2013].

Employment Service 2012c, Arbetsförmedlingens Aterrapportering Strategiförökade informationsinsatserom arbetskraftsinvandring från tredjeland, Bilaga, Available from: < http://www. arbetsformedlingen.se>. [Last accessed 24.9.2013].

Faist, T 2000, 'Transnationalization in international migration: implications for the study of citizenship and culture', Ethnic and Racial Studies, Vol. 23, no. 2, pp. 189-222, DOI: 10.1080/014198700329024

Government Offices of Sweden 2008, New Rules for Labour Migration, Available from: < http://www.government.se>. [Last accessed 24.9.2013].

Hollifield, JF 1986, 'Immigration Policy in France and Germany: Outputs versus Outcomes', The ANNALS of the American Academy of Political and Social Science May 1986 vol. 485 no. 1 113-128, DOI: $10.1177 / 0002716286485001010$

Hollifield, JF 2008, 'The politics of international migration: How can we "bring the state back in"' in Migration theory. Talking across disciplines, ed C Brettell \& JF Hollifield, Routledge, pp. 137-185. 


\section{Nordic Journa}

\section{of Migration Research}

HRF 2012, Till vilket pris som helst? En uppföljning av arbetskraftsmingranters villkorihotell-och restaurangbranschen, Available from: < http://www.hrf.net>. [Last accessed 24.9.2013].

IOM 2012, Labour migration and human development: 2011 Annual Report, International Organization for Migration, Geneva, Switzerland, Available from: < http://www.iom.int>. [Last accessed 24.9.2013]

Iredale, R 2001, 'The migration of professionals: theories and typologies', International migration, Vol. 39, no. 5, pp. 7-26, DOI: 10.1111/1468-2435.00169

Jonsson, H 2012, Ny väg in - Rapport irakiska AT-ärenden 2011

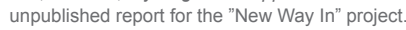

Koehler, J, Laczko, F, Aghazarm, C \& Schad, J 2010, Migration and the Economic Crisis in the European Union: Implications for Policy, International Organization for Migration, Brussels

Kuptsch, C 2012, 'The Economic Crisis and Labour Migration Policy in European Countries', Comparative Population Studies Zeitschrift für Bevölkerungswissenschaft, Vol. 37, no. 1-2, pp. 15-32

Katz, E \& Stark, O 1987, 'International Migration under Assymetric Information', The Economic Journal, Vol. 97, September, pp. 718-726

Kuvik, A 2013, 'Skilled Migration in Europe and Beyond: Recent Developments and Theoretical Considerations' in An Introduction to International Migration Studies: European Perspectives, ed M Martiniello and J Rath, Amsterdam University Press, pp. 211236

Massey, DS 1990, 'Social structure, household strategies, and the cumulative causation of migration', Population Index, Vol. 56 , no. 1 , pp. 3-26.

Massey, DS 1999, 'International migration at the dawn of the twenty $\square$ first century: The role of the state', Population and Development Review, Vol. 25, no. 2, pp. 303-322.

Menz, G 2008, The political economy of managed migration: Nonstate actors, europeanization, and the politics of designing migration policies, OUP Oxford

Meyers, E 2000, 'Theories of International Immigration Policy - A Comparative Analysis', International Migration Review, Vol. 34, no. 4 ,pp. $1245-1282$

Murhem, S \& Dahlkvist, A 2011, 'Arbetskraftsinvandring och egenintresse - Arbetsmarknadens parter och liberaliseringen av det svenska regelverket för arbetskraftsinvandring', Arbetsmarknad \& Arbetsliv, Vol. 17, no. 3, pp. 37-51

OECD 2011, Recruiting Immigrant Workers: Sweden, OECD Publishing, DOI 10.1787/9789264167216-en

OECD 2012, Harnessing the skills of migrants and diasporas to foster development: policy options, OECD \& French Ministry of Foreign Affairs, Available from: <http://www.oecd.org>. [Last accessed 24.9.2013]

Oxford Research 2009, Är Sverige attraktivt? Utländsk kvalificerad arbetskrafts syn på Sverige som land att arbeta och bo $i$, Available from: <http://www.svensktnaringsliv.se>. [Last accessed 24.9.2013].

Papademitriou, D \& Sumption, M 2011, Rethinking Points Systems and Employer Selected Immigration, Washington DC: Migration Policy Institute, Available from: <http://www.migrationpolicy. org>. [Last accessed 24.9.2013]

Pelling, L \& Nordlund, V 2012, Ny väg in: Intervjustudie, draft version 2012-10-05, Global utmaning

Petersson, S 2012, Bemanningsföretagens roll i rekryteringen av utländsk arbetskraft, Rapport 2012:1 Stockholms universitets Linnécentrum för Integrationsstudier (SULCIS), Stockholms University

Piore, MJ 1979, Birds of passage: Migrant labor and industrial societies, Cambridge University Press, Cambridge and New York

Regine, P 2011, Labour Migration Management as Multidimensional Border-drawing: A Comparative Interpretive Policy Analysis in the EU, University of Bath: Department of Social and Policy Sciences

Quirico, M 2012, Labour migration governance in contemporary Europe. The case of Sweden, Fieri Working papers, Torino, Italy

Ruhs, M 2011, Openness, Skills and Rights: An Empirical analysis of labour immigration programmes in 46 high-and middle- income countries, Centre on Migration, Policy and Society, Working Paper No. 88, University of Oxford

Shaw, MN 1997, International law (fourth edition), Cambridge University Press

Statistics Sweden 2012, Trender och Prognoser 2011: befolkningen utbildningen arbetsmarknaden med sikte på år 2030, Available from: <http://www.scb.se>. [Last accessed 24.9.2013].

Swedish Trade Union Confederation 2013, Fusk och utnyttiande om avregleringen av arbetskraftsinvandringen, Available from: < http://www.lo.se/>. [Last accessed 04.3.2014].

TCO 2012, Bättre kontroll för bibehållen öppenhet - Sả kan reglerna för arbetskraftsinvandring förbättras, Available from: <http:// www.tco.nu>. [Last accessed 24.9.2013].

Wingborg, M \& Fredén, J 2011, Mors lilla Olle II: Hur gick det för blåbärsplockarna sommaren 2011?, Swedwatch rapport \#43, Available from: <http://www.swedwatch.org>. [Last accessed 24.9.2013].

Zlotnik, H 1992, 'Empirical Identification of International Migration Systems' in International Migration Systems: A Global Approach. Ed MM Kritz, LL Lim and H Zlotnik, Clarendon Press: Oxford, pp. $19-40$.

Zolberg, AR 1981, 'International Migrations in Political Perspective' in Global Trends in Migration, ed M Kritz, C Keely \& S Tomasi, Staten Island: Center for Migration Studies, pp. 15-51.

Zolberg, AR 1989, 'The next waves: Migration theory for a changing world'. International Migration Review, Vol. 23, no. 3, pp. 403430

Interviews

BMC: Kundu, P. CEO, BeeMobile Consulting AB, October 22, 2012

BP: Lundberg, C. CEO, Norrskensbär (berry picking company), October 15, 2012

CSE: $\quad$ Ekenger, K. Labour migration expert, the Confederation of Swedish Enterprise, October 8, 2012

EC: Tersmeden, P. Labour law expert, Teknikföretagen (Engineering Companies), October 15, 2012

GC: Pelling, L. Research Manager, Global Challenge (think thank), October 19, 2012

HRF: Persson, P. Ombudsman, Hotel and Restaurant Workers' Union, October 9, 2012

IT: von Essen, F. Public Affairs Expert, IT \& Telekomföretagen, October 16, 2012

MB: Delgado, A. Head of Department, the Swedish Migration Board, October 11, 2012

PES 1: Pärlemo, L. Investigator, the Swedish Public Employment Service, October 8, 2012

PES 2: Myrgren, M. EURES-advisor, the Swedish Public Employment Service, October 12. 2012

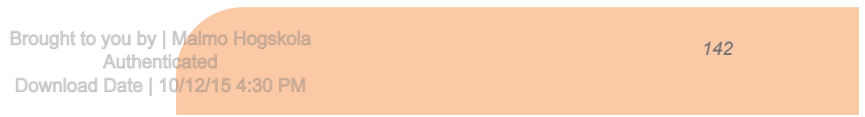


Si: Arenbjörk, M. Project Manager, the Swedish Institute, October 8, 2012

SCF: Akerlind, M. Vice President, the Swedish Construction Federation, October 15, 2012

TS: Blomqvist, H. CEO, Telescope Software AB, October 23, 2012 TUCW: Carlsson, C. Ombudsman, Byggnads (trade union for construction workers), October 18, 2012 
II 



\title{
Recruitment to Occupations with a Surplus of Workers: The Unexpected Outcomes of Swedish Demand-Driven Labour Migration Policy
}

\author{
Henrik Emilsson*
}

\begin{abstract}
This article studies the outcomes of the 2008 labour-migration policy change in Sweden, when most state control was abolished and an employer-led selection was introduced. The main goal was to increase labour migration from third countries to occupational sectors experiencing labour shortages. The article compares the volume, composition and labourmarket status of labour migrants who arrived before the change in the law with those who arrived after. Labour migrants from EU countries are used as a control group to assess any eventual influence from non-migration policy determinants. The main outcome of the policy change is that non-EU labour migration increased - an effect entirely due to the rise in labour migration to surplus occupations. Changes in the composition of the labour migrants explains why those who came after the law change have, on average, a worse labour market position.
\end{abstract}

\section{INTRODUCTION}

What happens when the state entrusts the power to select labour migrants to individual employers? This question seems unlikely in a world where countries tend to increase their efforts to control migration flows. When it comes to labour migration, for example, there is a trend towards more selective policies, where states try to attract high-skilled migrants while restricting low-skilled migrants to temporary migration programmes with less access to rights (De Somer, 2012; Ruhs, 2013). In general, there is a trade-off between generous admission policies and the set of rights which labour migrants have. The rights are also often very different for low- and high-skilled labour migrants (Ruhs, 2013). None of these trends applies to the Swedish case. In fact, the country has done the complete opposite. The new law on labour migration that came into force on 15 December 2008 abolished the labour market test and introduced a non-selective demand-driven labour migration policy where individual employers were given the power to select migrant workers.

The aim of this article is to study the outcomes of the 2008 labour migration policy change in Sweden. It follows the conceptual framework of migration policy effects and effectiveness outlined by Czaika and de Haas (2013). The policy outcomes are analysed by comparing the volume, composition and labour market status of the labour migrants who came after the reform with those of

* Malmö University, Sweden 
migrants who came before the change in the law. Labour migrants from EU countries during the same period are used as a control group to assess any eventual influence from non-migration policy determinants. The outcome is analysed in relation to the main policy objective - to increase labour migration from third countries and resolve Sweden's shortage of workers. The article studies the short-term effects - in this case an advantage, since the government in later years has changed some administrative routines to try to correct some of the shortcomings in the policy.

The Swedish case provides an ideal opportunity to study the outcomes of a new policy. Firstly, we have a clear change that affected the policy for all kinds of labour migration from outside the EU/EEA. The labour market test was abolished and the policy is now one of the most pure examples of a demand-driven labour migration model which is estimated to be one of the world's most open (OECD, 2011). Secondly, the Swedish statistical register allows for a follow-up of the total population of labour migrants, including their position on the labour market.

Even though the article is about Sweden, it is also of general interest. It contributes to the discussion about the relation between migration policy and migration flows, and about labour migration management - specifically what happens when a labour market test is abolished and the power of selection of labour migrants is handed over to individual employers. Most research on labour migration tends to focus on explaining policy outputs - i.e. why states choose different kinds of policy (for a good overview, see Balch, 2010). The literature on the outcomes of labour migration policies is much sparser. Most studies that have tried to measure these have looked at total or net immigration (Czaika and de Haas, 2013). Only a few have looked specifically at policy outcomes for labour migration and those have been conducted in traditional immigration countries with a longer history of labour migration, such as Canada, Australia and New Zealand (Bedford and Spoonley, 2014).

The article is structured as follows. The next section discusses the different models and programmes which countries can choose when selecting labour migrants in the light of changing labour market characteristics in a post-industrial economy. Then comes a short overview of Swedish labour migration regulations and inflow since World War II, highlighting, in particular, the recent 2008 reform and comparing it with the old model of selection of labour migrants. The next two sections cover, respectively, the conceptual framework for measuring the outcomes of labour migration policy change, and the material and method used. The penultimate section presents the empirical material, which shows how the policy change has affected the volume, composition and labour market status of the labour migrants. The concluding discussion summarises the findings and discusses their implications for past and future research.

\section{THE DEMAND FOR AND SELECTION OF LABOUR MIGRANTS}

The demand for labour migrants is different today from that of the 1960s and 1970s. The macroeconomic changes that have occurred over the past forty or so years - globalization, de-industrialization, the rationalization of production, the shift away from Fordist mass production, and regional integration - have, according to Menz and Caviedes (2010), had four consequences. First, the general labour shortage during the 1960s has changed to labour shortages in specific occupations and industries - for example, in healthcare, agriculture and construction. Second, policies are increasingly influenced by globalization and Europeanization; labour migrants come from different - as well as more - countries than ever before. EU citizens can now freely migrate for work within the EU, which partly satisfies employers' labour needs. Third, there has been a significant privatization of the control of labour migration. Private actors such as recruitment agencies, and international organizations such as the ILO, are playing an increasing role in the stimulation or prevention of the inflow of labour. Fourth, globalization and technological advances shrink geographical distances 
and promote the transfer of information on European employment opportunities. Accordingly, comparisons between labour migration today and that of the 1960s and 1970s should be undertaken with caution.

In this article, I elaborate on the first consequence, since it is important for understanding both labour migration policy and labour migration flows. According to the literature on varieties of capitalism - or VoC (see Hall and Soskice, 2001), labour migration policies are increasingly driven by industry-specific preferences which tend to differ between countries depending on their political economy (Devitt, 2011; Menz, 2008). According to Menz (2008), the profile of desirable labour migrants is conditioned by the particularities of the individual systems of political economy based on structural relationships between states, capital and labour. Ruhs and Anderson (2010) have suggested, in line with the $\mathrm{VoC}$ literature, that the demand for migrant workers in many sectors can be explained by "system effects" that produce certain types of domestic labour shortage as a result of institutional and regulatory frameworks on the labour market and from other welfare and social policies. Countries with a coordinated market economy, such as Sweden, are predicted to "place much greater importance on skills and close their doors almost entirely for low-skilled migration, with extremely limited exceptions, such as temporary agricultural workers" (Menz, 2008: 268). As we shall see below, the theory corresponded well with the volume and composition of labour migration to Sweden from 1972 up until the new law in 2008. During the 1980s and 1990s, there were only a few hundred labour migrants yearly from outside the Nordic countries, mainly highly educated specialists. The political economy explanation cannot, though, easily explain why Sweden chose a different policy in 2008 .

In addition to a demand for specific skills and occupations, many countries also try to attract the highly skilled in general, who are thought to be beneficial to the economy at large. Most countries have, therefore, opted for selective labour migration policies in order to attract these high-skilled migrants and/or meet the specific needs of the domestic labour market. However, not only do the policies discriminate in the selection of desired labour migrants, but they also tend to give the migrants different rights depending on their skill level. Labour market programmes that target highskilled workers are more open and grant migrants more rights than programmes targeting the lower-skilled (Ruhs, 2013). As we shall see later, Sweden has chosen a different overall strategy, with both openness and extensive rights regardless of skill level.

In the migration literature, two models for selecting labour migrants are usually highlighted: demand-driven and supply-driven. Most countries tend to use one of the models as a base but pragmatically complement it with aspects of the other model in order to attract the desired labour. Empirical knowledge of the results of the different models of labour migration selection is limited, and only a few studies and reports exist which give an account of the likely advantages and disadvantages of each model (Chaloff and Lemaitre, 2009; Papademitriou and Sumption, 2011). The Swedish model is probably the most pure example of a demand-driven model, since it does not take into account supply-related factors such as the migrant's education level, age, work experience and language skills.

\section{LABOUR MIGRATION TO SWEDEN - AN OVERVIEW OF INFLOW AND REGULATIONS}

Labour migration to Sweden during the postwar period can be divided into three periods; from the end of World War II until the early 1970s, from 1972 until the new law was introduced in 2008, and the period since 2008 with the current system of labour migration.

From the end of the World War II to the beginning of the 1970s, on average just over 30,000 persons per year immigrated to Sweden, of whom a large majority were labour migrants. During 
the 1940 s and 1950 s, it was primarily skilled workers in industry and the hotel and restaurant sector who were recruited as a result of a collective transfer of foreign workers organized through bilateral agreements or cooperation between Swedish companies, the public employment service and foreign employment agencies (Lundh and Ohlsson, 1999). In the mid-1950s, the demand for manual labour in the expanding manufacturing industry grew. The supply was provided by two sources of labour migrants. Many came from other Nordic countries (foremost Finland) as a result of the joint Nordic labour market that was created in 1954. The other large group during the 1960s and the beginning of the 1970s came from Mediterranean countries, especially Yugoslavia and Greece. Immigration to Sweden was, generally speaking, free from 1955 to 1967, which can be attributed mainly to the large general labour shortage which had predominated since the end of the war. During this time most labour migrants went to Sweden on tourist visas and applied for a job (Lundqvist, 2002). In 1967 the rules for non-Nordic labour immigration were tightened due to demands from the trade unions (Lundqvist, 2002). From then on, non-Nordic citizens who wanted to work in Sweden were required to arrange work permits and housing before entering the country. A labour market test was introduced to ensure that no native Swedish workers were available before a work permit could be granted. Despite the new rules, non-Nordic labour immigration continued to be relatively substantial until the recession in 1971 and 1972. In 1972, the Swedish Trade Union Confederation (LO) issued a circular calling for a more restrictive policy regarding the approval of work permits for non-Nordic citizens (Lundh and Ohlsson, 1999). Since then, the trade unions have been consistently averse to granting non-Nordic citizens work permits and, for the most part, the Employment Service has followed trade union recommendations.

In the second period, 1972 to 2008 , labour migration was governed by the guidelines issued in the 1968 and 1984 legislations (Ministry of Employment, 2005). There were a number of similarities with the current legislation. Labour migration was demand-driven and required a job offer from an employer; wages and employment conditions had to be equivalent to those applicable to domestic labour. However, there were significant differences between the two legislations. Before 2008, The Employment Service was required to carry out a labour market test to determine whether there were workers available in Sweden or other EU/EEA member-states before a work permit could be granted. The relevant trade unions were consulted on the conditions of employment and on the general labour situation in the industry concerned. The Migration Board then made the final decision based on a concrete job offer, except for seasonal work, which was decided upon by regional employment services. It is, though, a misconception that opportunities for labour migration were closed before December 2008. The Employment Service could, within the scope of the law, adapt the guidelines for work permits to changing labour market needs. This happened, for example, in January 2005, when the labour market tests were carried out earlier in the application process. It was made very clear that the most important aspect of the labour market test was to determine whether there was suitable manpower available closer to home and that this assessment should be more important than the level of education in cases of permanent residence. In addition to permanent work permits, temporary ones were given to three groups: persons on an international exchange, workers needed to fill temporary labour market shortages and those applying for seasonal work.

The 2008 law was a clear breach of a 40-year period of state- and union-controlled labour migration policy. In the new model, it is the employer, not state agencies and unions, who decides the need for labour and from where in the world the employer wishes to recruit. Sweden has resolved the complicated issue of forecasting labour shortages (Boswell, Stiller and Straubhaar, 2004) by giving employers full responsibility for the selection process. The only condition for obtaining a work permit is being in possession of an offer of employment paying a livable wage ${ }^{1}$ and that the level of pay is in line with applicable collective agreements and general insurance conditions. The trade union concerned is given the opportunity to express its views but does not have a veto. The principle of Community preference applies. ${ }^{2}$ In practice, this obligation is fulfilled if the employer 
advertises on the European job mobility portal - EURES - for ten days, but there are no serious checks to ascertain whether or not an employer has made the job offer public (Quirico, 2012). As the OECD (2011) noted, the labour migration model is based on trust, and assumes that the employers give preference to workers who already live in the country.

In the new model, the recruitment of workers from third countries does not greatly differ from that of workers from within the EEA. The main difference is that second-country citizens can freely travel to Sweden to look for work. For third-country citizens, work and residence permits must normally be arranged prior to leaving the country of origin. In certain cases, residence and work permits may be granted from Sweden. The preconditions are that the application is made during the 90-day visa-free period or before the entry visa expires and that the employment relates to work for which there is a labour demand. ${ }^{3}$ International students who have completed one semester of their studies are entitled to apply for work and residence permits from within Sweden. Asylum-seekers whose application has been rejected may also, under certain conditions, be granted a permit. A work permit is allocated for a maximum of two years, though it can be extended. The permit is linked to a particular occupation and employer for two years and then, in the event of a subsequent extension, to an occupation for a further two years. If a labour migrant has worked for an aggregate period of four out of the previous five years, a permanent residence permit is accorded. A labour migrant basically enjoys the same rights as other residents when working and living in Sweden. Family members are entitled to accompany the employee from Day 1, and automatically receive a work permit.

\section{LABOUR MIGRATION POLICY OUTCOMES}

Many researchers have noted that migration policies tend to fail (Castles, 2004) and produce different immigration flows from those expected or wanted, a phenomenon which Cornelius and Tsuda (2004) named "the control gap paradox". Boswell and Geddes (2011), for example, have observed that Germany found it hard to attract highly skilled labour migrants even after introducing a new green card in 2000; on the other hand, labour migration to the UK after the expansion of the EU in

TABLE 1

THE REGULATORY FRAMEWORK OF LABOUR MIGRATION BEFORE AND AFTER DECEMBER 2008

\begin{tabular}{|c|c|c|c|c|}
\hline & Assessment criteria & Time & Family & Categories \\
\hline \multirow[t]{6}{*}{$\begin{array}{l}\text { Old labour } \\
\text { migration } \\
\text { policy }\end{array}$} & $\begin{array}{l}\text { Permanent residence } \\
\text { permit for labour } \\
\text { market reasons }\end{array}$ & No limitations & Yes & $\begin{array}{l}\text { Not specified, determined } \\
\text { by the long term needs on } \\
\text { the labour market. }\end{array}$ \\
\hline & $\begin{array}{l}\text { Temporary labour } \\
\text { market shortage }\end{array}$ & $18+6$ months & Yes & $\begin{array}{l}\text { Skilled and experienced } \\
\text { professionals for short- } \\
\text { term shortages. }\end{array}$ \\
\hline & $\begin{array}{l}\text { International } \\
\text { exchange }\end{array}$ & Maximum 4 years & Yes & $\begin{array}{l}\text { Managerial employees/spe } \\
\text { cialists in international cor } \\
\text { porations }\end{array}$ \\
\hline & & 18 months & Yes & Trainees \\
\hline & & 12 months & Yes & Aupair \\
\hline & Seasonal workers & Maximum 3 months & No & $\begin{array}{l}\text { Workers in agriculture, } \\
\text { horticulture and forestry. }\end{array}$ \\
\hline 2008 policy & $\begin{array}{l}\text { Minimum wage } \\
\text { according to } \\
\text { occupational } \\
\text { standards }\end{array}$ & $\begin{array}{l}2+2 \text { years, then } \\
\text { permanent }\end{array}$ & Yes & $\begin{array}{l}\text { Same regulation for all } \\
\text { categories. }\end{array}$ \\
\hline
\end{tabular}


2004 was far higher than expected. As Czaika and de Haas (2013) note, the controversy about the effects of migration policy is rooted in the scarcity of empirical evidence and the conceptual fuzziness of the debate, where researchers tend to talk about gaps on different analytical levels (2013:488).

This article looks at migration policy outcomes - in this case the volume, composition and labour market position of the migrants. As a second step, the outcome is analysed in relation to the declared policy goals. Thus, the article will analyse both the policy's effects and its effectiveness (Czaika and de Haas, 2013:495), the first of which are the relations between the implemented regulations and the migration outcomes, while the second is that between migration policies on paper and the migration outcomes.

The aim of the Swedish reform was to facilitate the recruitment of labour from third world countries (Ministry of Justice, 2008). In the short term, it was supposed to ease the labour shortage in specific occupations and sectors (Government Offices of Sweden, 2008). This message is still communicated by the government. One recent example is the statement by the Swedish Minister for Migration, Tobias Billström, who, at the 2013 UN Commission on Population and Development, said that "the main driving-force for the Swedish reform was the recognition that there are labour shortages in Sweden that will not be filled solely by people living in Sweden or in other EEA countries". ${ }^{4}$ Labour recruitment to occupations where there are shortages is, thus, the most important indicator of the reform's effectiveness.

Although there are articles on the outcome of the 2008 reform, none of them systematically studies the outcomes of the new policy. The social partners have been active and published a number of reports. The Hotel and Restaurant Union (2012) has called attention to the bad working conditions in the restaurant industry. The Swedish Trade Union Confederation (2013) has concluded that a large proportion of employers are looking for low labour costs and not for unique skills, that the new law has primarily enabled labour migration to occupations where there is high unemployment, and that the current system is not able to prevent the exploitation of migrant workers. Employer organizations, on the other hand, have published reports that defend the reform and its outcomes, while pointing out that high taxes reduce Sweden's attractiveness for highly skilled migrants (Broryd and Glad, 2013; Ekenger, 2013; Ekenger et al., 2013). A more independent follow-up, commissioned by the Swedish government, was conducted by the OECD (2011). Regarding the outcome, they acknowledge that there has been no substantial increase in the number of work permits granted but that the reform has provided opportunities for recruitment to businesses and occupations that were previously excluded. The OECD also notes that most of the longer-term permits are for occupations where there is no shortage of labour. Emilsson (2014) found that labour migration since the reform is dominated by three major categories: those moving to skilled jobs as computer specialists or engineers, those taking low-skilled jobs in the private service industry and seasonal migrants picking berries. Many of the work permits are in occupations with a need for labour. At the same time, a substantial number come to work in low-skilled jobs in the private service sector, where there is already a large surplus of available workers. Vogiazides and Hedberg (2013) have carried out a more in-depth study of labour migration to restaurants and the berry-picking industry - they confirm a widespread trade in work permits. In many cases, especially in the restaurant industry, workers are paid significantly less and work longer hours than was stated in the employment offer submitted to the Migration Board.

\section{STATISTICAL DATA AND METHOD}

All statistical data in this report are from Statistics Sweden and the special database they set up for the Integration Fund project Labour Migrants in Sweden: A Follow-Up of the Swedish Law Change 
in 2008. The population in the database is retrieved from the Total Population Register (TPR) and consists of all persons aged 20 years and older who were registered in Sweden on 31 December at some point during the 2008-2012 period. Only persons with an expected length of stay of one year or more are registered with a municipality and added onto the population registry. Persons on the database are anonymised, and the material undergoes ethical screening. In the database a migrant's "reasons for settlement" can be identified, in this case both EU and non-EU labour migrants.

In order to examine the labour market position of migrants, the Swedish Standard Classification of Occupations (SSYK4) has been used to classify all occupations into one of four groups: surplus occupations, shortage occupations, other occupations and unknown occupations. The basis for the classification is the shortage index produced by the Employment Service. The Employment Service's (2013) re-occurring report - Where are the Jobs? - displays the current labour market situation and the prospects for around 200 occupations, covering approximately 80 per cent of the employment in the labour market. The estimation is based on employers' expected recruitment needs and the Employment Service's estimate of the availability of suitable workers one year in advance, aggregated from hundreds of local employment offices investigations. The Employment Service acknowledge some regional differences in the availability of workers in different occupations. The index is therefore adjusted for the number of workers in an occupation in every municipality in order to minimize the effects of local and regional differences. From these estimations, a shortage index is drawn up which shows a weighted average for the respective occupations ranging from 1 (large surplus of job-seekers) to 5 (severe shortage of job-seekers). In the 2013 shortage index, the Employment Service showed the situation from spring 2009 to spring 2013 (nine forecasts in all). Our aim was to capture the labour market situation over the whole period and construct an average shortage index number for all occupations. We define a shortage occupation as having an average value of between 3.65 and 5.00 and a surplus occupation as having an average value of 1.00-2.45. Occupations with a value between 2.46 and 3.64 are defined as other occupations (balance).

According to the above definitions, there was a shortage in 30 occupations and a surplus in $31 .^{5}$ We have made one change to the Employment Service's occupation shortage list. After a closer examination of the occupations, we have defined cooks as a surplus instead of a shortage occupation. Most evidence shows that labour migrants who are employed as cooks are working in lowqualified positions that are comparable to helpers in restaurants. For example, Jonsson's (2012) review of work permits for Iraqi chefs shows that a vast majority of their work permits are for working in fast-food restaurants and pizzerias. Another indication is that the cooks, on average, had a lower income than helpers in restaurants, which is a surplus occupation.

The database contains information on employment and occupations up until 2011. By following the labour migrants who immigrated in 2009 , we examined the situation two years after immigration. To gain a better understanding of the outcomes of the policy change, we compared the results with those who migrated for work before the new law came into force in 2008. To gain an additional comparison group, we also followed up on the 2008 and 2009 labour migrants from EU countries.

\section{LABOUR MIGRATION TO SURPLUS OR SHORTAGE OCCUPATIONS}

The statistics indicate that the new law contributed to an increase in labour migration from third countries. At over 70 per cent, the increase is quite large but the number of non-EU labour migrants is still low, especially in relation to other immigration categories. The increase should also be seen in relation to the slight decline of labour migration from the EU over the same time period (see Table 2). 
TABLE 2

LABOUR MIGRATION INFLOW TO SWEDEN OF NON-NORDIC CITIZENS 2005-2013

\begin{tabular}{|c|c|c|c|c|c|c|c|c|c|}
\hline Year & 2005 & 2006 & 2007 & 2008 & 2009 & 2010 & 2011 & 2012 & 2013 \\
\hline \multicolumn{10}{|l|}{$\begin{array}{l}\text { First time } \\
\text { work } \\
\text { permits }\end{array}$} \\
\hline $\begin{array}{l}\text { Non EU/ } \\
\text { EES- } \\
\text { citizens }\end{array}$ & 3631 & 3637 & 7187 & 11255 & 14905 & 14001 & 15158 & 17011 & 15974 \\
\hline $\begin{array}{l}\text { Non EU/ } \\
\text { EES- } \\
\text { citizens, } \\
\text { excluding } \\
\text { seasonal } \\
\text { work }\end{array}$ & 3135 & 3567 & 4829 & 7508 & 7705 & 9493 & 12337 & 11303 & 10059 \\
\hline $\begin{array}{c}\text { EU/EES- } \\
\text { citizens }\end{array}$ & 8671 & 10164 & 8884 & 8369 & 6275 & 7506 & 9926 & 10121 & 8173 \\
\hline \multicolumn{10}{|l|}{$\begin{array}{l}\text { Registered } \\
\text { in the } \\
\text { population } \\
\text { registry }^{\star \star}\end{array}$} \\
\hline $\begin{array}{l}\text { Non EU/ } \\
\text { EES- } \\
\text { citizens }\end{array}$ & 908 & 1132 & 1421 & 1817 & 3294 & 4826 & 6355 & 6048 & 5154 \\
\hline $\begin{array}{c}\text { EU/EES- } \\
\text { citizens }\end{array}$ & 3578 & 4802 & 4679 & 3882 & 2659 & 3502 & 4590 & 4859 & 4609 \\
\hline
\end{tabular}

Source: *Migration Board, **Statistics Sweden

TABLE 3

EMPLOYMENT STATUS, TWO YEAR AFTER IMMIGRATION, FOR 2008 AND 2009 EU AND NON-EU LABOUR MIGRANTS

\begin{tabular}{|c|c|c|c|c|c|}
\hline \multirow[b]{2}{*}{ Immigration cohort } & \multicolumn{2}{|c|}{ Employed } & \multicolumn{2}{|c|}{ Not employed } & \multirow[b]{2}{*}{ Total number } \\
\hline & Number & Percentage & Number & Percentage & \\
\hline 2008 non-EU & 1062 & 67,7 & 507 & 32,3 & 1569 \\
\hline 2009 non-EU & 1966 & 72,8 & 733 & 27,2 & 2699 \\
\hline 2008 EU & 3722 & 72,2 & 1434 & 27,8 & 5156 \\
\hline 2009 EU & 2818 & 73,8 & 1003 & 26,2 & 3821 \\
\hline
\end{tabular}

Source: Statistics Sweden, own calculations

Compared with the approximately 15,000 work permits issued in 2009 , few of the migrants are still in the country two years later. Most labour migration from third countries is seasonal migrants in the berry-picking industry and short-term highly skilled intra-corporate transfers (Emilsson, 2014). There are also indications that a relatively high number lose their jobs or quit their employment during the work-permit period. As we see in Table 3, more than one in five of the 2009 non-EU labour migration cohort was unemployed but still registered as living in Sweden at the end of 2011. All in all, the employment situation is approximately the same for all labour migration cohorts except for the 2008 non-EU cohort, where more were unemployed. The difference for the 2009 non-EU cohort is that all had temporary work permits and needed continuous employment in order to stay in the country. 
Table 4 shows the types of occupation the employed labour migrants were engaged in two years after immigration. If we compare the 2008 and 2009 non-EU cohorts, we find huge differences in the distribution of surplus and shortage occupations. Before the reform, 30 per cent of the non-EU labour migrants worked in shortage occupation and only 22 per cent in surplus ones. After the reform, only 12 per cent worked in shortage occupations and 44 per cent in surplus. If we look at absolute numbers, labour migration from third countries to shortage occupations actually decreased. It is more difficult to compare these figures with EU labour migrants since many of the latter had an unknown occupation, but it seems that fewer came to Sweden to work in surplus occupations than the 2009 non-EU labour migrants.

Table 5 shows the average monthly income for the different labour migration cohorts, together with their employment status and type of occupation. When we look at all employed migrants, the average monthly income decreased by 6,000 SEK, which is an 18 per cent drop for the 2009 nonEU labour migrants compared with those who came before the law changed. The drop in income owes much to the change in distribution between the types of occupation. While the 2009 non-EU cohort saw lower average incomes in "other" occupations, average incomes in shortage and surplus occupations were actually higher the year after the change in the law. EU labour migrant cohorts had about the same average income in both years, on a par with the 2009 non-EU migrants. If the unemployed are included, the difference in average income between the 2008 and 2009 non-EU cohorts is significantly reduced.

In sum, before the law changed, non-EU labour migrants performed better than EU labour migrants in the Swedish labour market. They had a higher average income and a more favourable composition whereby a large share went to Sweden to work in shortage occupations. After the law changed, non-EU labour migrants were similar to EU labour migrants when it came to income, but

TABLE 4

TYPE OF OCCUPATION, TWO YEAR AFTER IMMIGRATION, FOR 2008 AND 2009 EU AND NON-EU LABOUR MIGRANTS THAT ARE EMPLOYED (PER CENT)

\begin{tabular}{|l|ccccc|}
\hline Immigrant cohort & Shortage & Surplus & Other & Unknown & Total number \\
\hline 2008 non-EU & 29,5 & 22,1 & 41,3 & 7,1 & 1062 \\
2009 non-EU & 12,1 & 44,0 & 40,4 & 3,5 & 1966 \\
2008 EU & 17,0 & 17,0 & 41,8 & 24,2 & 3722 \\
2009 EU & 15,2 & 18,0 & 38,5 & 28,2 & 2818 \\
\hline
\end{tabular}

Source: Statistics Sweden, own calculations

TABLE 5

AVERAGE MONTHLY INCOME (SEK), TWO YEARS AFTER IMMIGRATION, FOR 2008 AND 2009 EU AND NON-EU LABOUR MIGRANTS IN DIFFERENT TYPES OF OCCUPATIONS

\begin{tabular}{|l|rrrrrrr|}
\hline & \multicolumn{7}{c|}{ Employed } \\
\cline { 2 - 6 } $\begin{array}{l}\text { Immigrant } \\
\text { cohort }\end{array}$ & Shortage & Surplus & Other & Unknown & $\begin{array}{c}\text { All } \\
\text { Employed }\end{array}$ & $\begin{array}{c}\text { Not } \\
\text { employed }\end{array}$ & All \\
\hline 2008 non-EU & 34,405 & 17,002 & 38,303 & 46,909 & 33,048 & 793 & 22,626 \\
2009 non-EU & 39,704 & 18,459 & 31,973 & 34,672 & 27,045 & 1,101 & 19,999 \\
2008 EU & 40,453 & 16,702 & 28,328 & 21,431 & 26,747 & 1,216 & 19,646 \\
2009 EU & 40,505 & 17,365 & 31,523 & 18,677 & 26,714 & 1,534 & 20,104 \\
\hline
\end{tabular}

Source: Statistics Sweden, own calculations 
more concentrated in surplus occupations. There are also signs that the reform has led to substantial substitution effects (de Haas, 2011) in the asylum system. Emilsson et al. (2014) found that a majority of the 2009 labour migrants had applied for asylum before or after being granted a work permit. While some had applied for asylum in the years before they applied for a work permit, most did so after the work permit was granted. Thus, many used their work permit to get a visa to Sweden in order to apply for asylum.

\section{CONCLUDING DISCUSSION}

This article has studied the policy outcomes of the 2008 Swedish law which introduced a demanddriven labour migration model without a labour market test. In order to analyse the outcomes, the volume, composition and labour market position of the labour migrants who came both before and after the reform are compared. In order to control for other determining factors for these outcomes - for example, a changing demand in the labour market - EU labour migrants are used as a control group.

The main outcome of the 2008 law is that labour migration into surplus occupations increased. This, in turn, led to a lower average income for labour migrants. I argue that this is a direct effect of the policy change, since there were no visible changes in composition and income for EU labour migrants over the same period. There is a clear gap between the outcomes of the policy and the main policy goal of attracting non-EU labour migrants into shortage occupations. Since the new law did change the labour migration outcome, though not in line with its goals, the policy effectiveness must be considered low, especially since most of the outcomes went in the opposite direction to the policy goals. The new law also led to substantial substitution effects, clearly reflected by the strong interrelationship between labour migration and the asylum system.

One problem when studying policy effectiveness is the potential difference between policy on paper and its interpretation and implementation in practice. Thus, both implementation and efficiency gaps can be the cause of a possible policy failure (Czaika and de Haas, 2013). This is also an important observation in the Swedish case. For example, an employment contract needs to fulfil certain conditions in order to be accepted. However, in reality, these have been found to be very difficult to uphold and control. It is not, though, in the Swedish case, an implementation problem but more of a policy problem, since the new law did not allow for controls. It is hard to blame the implementation when the Migration Board did not have the tools to work efficiently against potential abuse of the labour migration system. In my estimation, the outcome can therefore be seen as a policy effect rather than a failure of implementation. Also, in the Swedish case, implementation effects are believed to have less importance due to the design of the labour migration policy, which involves very little bureaucracy.

The findings are in line with the control gap paradox first outlined by Cornelius and Tsuda (2004:3). The outcome does not mean that migration policy is irrelevant. Migration policies often fail to achieve their declared objectives or have unintended consequences due to contextual factors of which policymakers are ignorant or simply ignore - such as strong social and economic push factors in the countries of origin and pull factors in the receiver society that elude the control of national governments.

Why is it, then, that a demand-driven labour migration model like the Swedish one mainly attracts labour migration to surplus occupations? Demand as well as supply factors can help us to understand the outcome. There are many indications that supply factors play a very important role for the effects of the 2008 law on labour migration. Many people want to leave their country of origin irrespective of whether or not there is a demand for their labour. To leave a difficult or hopeless situation and obtain a work visa to Sweden is, for many, a stronger driving force than moving 
to a specific job. The new labour migration model provided a new opportunity structure for migration to Sweden besides the asylum system. The best example of this is perhaps the mixing of the labour migration and the asylum systems. Demand factors help to explain where in the labour market those who wish to leave their country of origin actually end up. There is plenty of evidence to show that the demand for foreign workers is low in most sectors of the Swedish labour market (Bevelander et al., 2014). In many shortage occupations, it is necessary to speak the language and/ or to have a special accreditation to be employable. This is in line with Chaloff and Lemaitre's (2009) claims that a demand-driven labour migration model is not suitable for countries with languages that are not widely spoken internationally. Instead, the demand is concentrated in the more unregulated private service sector, where it is difficult for unions and authorities to enforce standard wage levels and collective agreements.

\section{NOTES}

1. In practice this means a salary of at least 13,000 SEK (1,400 Euros) per month, as the Migration Board has interpreted the regulation as saying that the person must earn enough to not be entitled to income support from the municipality.

2. The principle of "Community preference" is defined by the EU in the following terms: "Member States will consider requests for admission to their territories for the purpose of employment only where vacancies in a Member State cannot be filled by national and Community manpower or by non-Community manpower resident on a permanent basis in that Member State and already forming part of that Member State's regular labour market".

3. Regulated by the "shortage list" drawn up by the Employment Service.

4. Statement 24 April 2013 at the UN Commission on Population and Development. Agenda item 4, general debate "National experiences in population matters: new trends in migration: demographic aspects".

5. Shortage occupations: Armed forces, computer systems designers, analysts and programmers, computing professionals not elsewhere classified, civil engineers, electrical engineers, electronics and telecommunications engineers, mechanical engineers, mining engineers, metallurgists and related professionals, medical doctors, dentists, midwives, emergency room nurses, paediatric nurses, district nurses, vocational teaching professionals, education methods specialists and related professionals, civil engineering technicians, electrical engineering technicians, mechanical engineering technicians, ships' engineers, operating theatre nurses, psychiatric nurses, radiology nurses, pre-primary education teaching associate professionals, miners, shot firers and quarry workers, floor layers, plumbers, sheet-metal workers, motor vehicle mechanics and fitters

Surplus occupations: Biologists and related professionals, personnel and careers professionals, authors, journalists and related professionals, public service administrative professionals, administrative professionals of special-interest organisations, photographers, Image and sound recording equipment operators, administrative secretaries and related associate professionals, office secretaries, numerical clerks, stock clerks and storekeepers, other office clerks, receptionists, transport information clerks, cooks, child-care workers, assistant nurses and hospital ward assistants, home-based personal care and related workers, attendants, psychiatric care, shop salespersons - food stores, shop salespersons - non-food stores, building caretakers, mechanical-machinery assemblers, electrical- and electronic-equipment assemblers, metal-, rubber- and plastic-products assemblers, lifting-truck operators, ships' deck crews and related workers, helpers and cleaners in offices, hotels and other establishments, helpers in restaurants, doorkeepers and related workers, mining and construction labourers.

\section{REFERENCES}

Balch, A.

2010 Managing Labour Migration in Europe: Ideas, Knowledge and Policy Change, CCIS Working Paper. 
Bedford, R. and P. Spoonley

2014 "Competing for Talent: Diffusion of An Innovation in New Zealand's Immigration Policy", International Migration Review, 48(3): 891-911.

Bevelander, P., H. Emilsson, K. Magnusson and S. Osanami Törngren

2014 Utfallet av den nya lagen om arbetskraftsinvandring. FORES, Stockholm.

Boswell, C., and A. Geddes

2011 Migration and Mobility in the European Union, Palgrave Macmillan.

Boswell, C., S. Stiller, and T. Straubhaar

2004 Forecasting Labour and Skills Shortages: How Can Projections Better Inform Labour Migration Policies? Hamburg Institute of International Economics.

Broryd, A., and B. Glad

2013 Utmaningar kring regelverket för arbetskraftsinvandring från tredje land: Slutrapport pilotstudie inom gröna näringarna samt bärplockning avseende år 2012, Svenskt Näringsliv.

Castles, S.

2004 "Why Migration Policies Fail", Ethnic and Racial Studies, 27(2): 205-227.

Chaloff, J., and G. Lemaître

2009 Managing Highly-Skilled Labour Migration: A Comparative Analysis of Migration Policies and Challenges in OECD Countries, OECD Social, Employment and Migration Working Papers No.79, OECD Publishing.

Cornelius, W.A. and T. Tsuda

2004 "Controlling Immigration: The Limits of Government Intervention", in W.A. Cornelius, T. Tsuda, P.L. Martin and J.F. Hollifield (Eds.), Controlling Immigration: A Global Perspective. Stanford University Press, Stanford, California: 3-48.

Czaika, M. and H. de Haas

2013 "The effectiveness of immigration policies", Population and Development Review, 39(3): 487-508. de Haas, $\mathrm{H}$.

2011 The Determinants of International Migration, IMI/DEMIG working paper, International Migration Institute, University of Oxford.

De Somer, M.

2012 Trends and Gaps in the Academic Literature on EU Labour Migration Policies, CEPS Papers in Liberty and Security in Europe No. 50, CEPS.

Devitt, C.

2011 "Varieties of Capitalism, Variation in Labour Immigration", Journal of Ethnic and Migration Studies, 37(4): 579-596.

Ekenger, K.

2013 Fackligt veto kan ge inställd talangjakt, Svenskt Näringsliv.

Ekenger, K., J. Fall, and T. Krantz

2013 Sverige - ett lockande land för talanger? En studie av val av destinationsland för högkvalificerade invandrare. Svenskt Näringsliv.

Emilsson, $\mathrm{H}$.

2014 "Who Gets In and Why: The Swedish Experience with Demand Driven Labour Migration - Some Preliminary Results", Nordic Journal of Migration Research, 3(4): 134-143.

Emilsson, H., K. Magnusson, S. Osanami Törngren, and P. Bevelander

2014 The World's Most Open Country: Labour Migration to Sweden After the 2008 Law, Current Themes in IMER Research Number 15, Malmö University.

Employment Service

2013 Var finns jobben? Bedömning till och med första halvåret 2014 och en långsiktig utblick

Government Offices of Sweden

2008 Nya regler för arbetskraftsinvandring.

Hall, P.A., and D.W. Soskice

2001 Varieties of Capitalism: The Institutional Foundations of Comparative Advantage, Wiley Online Library.

Hotel and Restaurant Union

2012 Till vilket pris som helst? En uppföljning av arbetskraftsmigranters villkor $i$ hotell- och restaurangbranschen. 
Jonsson, $\mathrm{H}$.

2012 Ny väg in - Rapport irakiska AT-ärenden 2011, Unpublished document from the "New Way In" project.

Lundh, C. and R. Ohlsson

1999 Från arbetskraftsimport till flyktinginvandring, 2nd edn. SNS Förlag, Stockholm.

Lundqvist, $\mathrm{T}$.

2002 Arbetskraft och konkurrensbegränsning: Aktörsperspektiv på den svenska modellen och framtiden. Institutet för Framtidsstudier, Stockholm.

Menz, G.

2008 The Political Economy of Managed Migration: Nonstate Actors, Europeanization, and the Politics of Designing Migration Policies, OUP Oxford.

Menz, G. and A. Caviedes

2010 "Introduction: Patterns, Trends, and (Ir)Regularities in the Politics and Economics of Labour Migration in Europe", in G. Menz and A. Caviedes (Eds.), Labour Migration in Europe. Palgrave Macmillan, Basingstoke: 1-22.

Ministry of Employment

2005 "Arbetskraftsinvandring till Sverige - befolkningsutveckling, arbetsmarknad i förändring, internationell utblick", SOU, 2005: 50.

Ministry of Justice

2008 Bill 2007/2008:147 Nya regler för arbetskraftsinvandring.

OECD

2011 Recruiting Immigrant Workers: Sweden, OECD Publishing.

Papademitriou, D. and M. Sumption

2011 Rethinking Points Systems and Employer Selected Immigration. Migration Policy Institute, Washington DC.

Quirico, M.

2012 Labour Migration Governance in Contemporary Europe. The Case of Sweden, Fieri Working papers, Turin, Italy.

Ruhs, M.

2013 The Price of Rights: Regulating International Labor Migration, Princeton University Press.

Ruhs, M. and A. Anderson (Eds.)

2010 Who Needs Migrant Workers? Labour Shortages, Immigration, and Public Policy. Oxford University Press, Oxford.

Swedish Trade Union Confederation

2013 Fusk och utnyttjande - om avregleringen av arbetskraftsinvandringen, LO-distribution.

Vogiazides, L. and C. Hedberg

2013 "Trafficing for Forced Labour and Labour Exploitation in Sweden: Examples from the Restaurant and the Berry Industries", in N. Ollus, A. Jokinen and M. Joutsen (Eds.), Exploitation of Migrant Workers in Finland, Sweden, Estonia and Lithuania: Uncovering the Links Between Recruitment, Irregular Employment Practices and Labour Trafficking. European Institute for Crime Prevention and Control, Helsinki. 

III 



\title{
A Local Dimension of Integration Policies? A Comparative Study of Berlin, Malmö, and Rotterdam
}

\author{
Rianne Dekker \\ Erasmus University Rotterdam \\ Henrik Emilsson \\ Malmö University \\ Bernhard Krieger \\ University of Potsdam \\ Peter Scholten \\ Erasmus University Rotterdam
}

This study examines three theses on local integration policies by a qualitative comparative case study of integration policies in three cities in three different countries (Berlin, Malmö, and Rotterdam). We found little evidence of a congruent local dimension of integration policies. Local policies resemble their national policy frameworks fairly well in terms of policy approaches and domains. Our multi-level perspective shows that this is not the result of top-down hierarchical governance, but rather of a multilevel dynamic of two-way interaction. Local policy legacies and local politics matter and national policies are also influenced by local approaches of integration.

\section{INTRODUCTION}

Migrant integration policies have often been defined in terms of national models of integration (Brubaker 1992; Koopmans and Statham 2000; Castles and Miller 2009 [1993]). This idea of national models has been challenged by a growing interest in the local dimension of migrant integration policies. Studies indicate that local governments do not just implement

[Minor typographical changes have been made to this article since it was first published.]

(C) 2015 by the Center for Migration Studies of New York. All rights reserved. 
national policies, but that they increasingly formulate policies as well (Alexander 2003, 2007; Penninx et al. 2004; Penninx 2009; Caponio and Borkert 2010; Scholten 2013). Hence, there is a need to attend to local integration frames and to question whether there is a specifically local dimension to integration policies.

Recent studies have provided a number of explanations for congruencies and incongruences between local and national policies as well as between local policies in different cities. Next to advocates of national models of integration policies, some scholars argue that there is a specific local dimension of integration policies characterized by either a greater tendency to accommodate ethnic diversity and solve integration problems in pragmatic ways (Poppelaars and Scholten 2008; Caponio and Borkert 2010; Jørgensen 2012) or a more exclusionist approach to migrants (Mahnig 2004; Ambrosini 2013). These studies argue that there is a distinct local model of integration that applies to cities even if in different countries. Horizontal modes of knowledge exchange and policy learning between cities would reinforce such congruencies between local integration policies.

Others have claimed that there are neither national nor local models of integration, arguing that local policies are uniquely shaped by the specific problem, political, and policy settings in the different cities (Alexander 2003; Scholten 2013). Focusing much more on how the local context shapes processes of policy framing, this would imply that the local dimension of integration policies involves incongruences between cities as well as between national and local governments.

The aim of this study is to contribute to existing literature on migrant integration policies operating at different levels of governance and in particular, the role of cities as sites of integration. We explore three theses that can be analytically distinguished by different expectations for congruencies between local policies and between local policies and their respective national policy contexts in three European cities: Berlin, Malmö, and Rotterdam. Selecting three cities with relatively large migrant populations but from three countries with different national integration traditions allows us to capture differences on the national-local as well as the local-local dimension.

We will address the following research question: To what extent is there a specific local dimension of migrant integration policies in Berlin Malmö and Rotterdam, and how can this be explained? This question can be differentiated into two subquestions. First, to what extent are there 
congruencies and incongruences between local policies in the various cities (horizontal dimension)? And second, to what extent are there congruencies or incongruences between national and local policies (vertical dimension)? For both dimensions, we take into account institutional ways of interaction between the different government entities as an understanding of (in) congruences.

\section{A MULTI-LEVEL PERSPECTIVE ON MIGRANT INTEGRATION: THREE THESES}

Scholars such as Alexander (2003, 2007), Penninx et al. (2004), and Jørgensen (2012) describe how local governments have increasingly been developing their own integration policies. This spurred academic debate on the characteristics of this local level of policies vis-à-vis national policies. In the literature, we can analytically distinguish three theses on how local integration policies relate to national policies and to each other. They encompass sometimes more than one strand of literature. We refer to them as the local dimension, the localist and the national models thesis.

The first thesis claims that as local governments are confronted with migrant integration issues more directly than national governments, they will respond in rather similar ways to migrant integration. One strand of literature contends that local governments are generally more accommodative to ethnic differences (Borkert and Bosswick 2007; Vermeulen and Stotijn 2010). As they are often closely cooperating with immigrant organizations and representative boards, they are more inclined than national governments to respond to immigrants' needs (Bousetta 2001; Marques and Santos 2004; Moore 2004; Schrover and Vermeulen 2005; Poppelaars and Scholten 2008). This phenomenon of "pragmatic problem-coping" has been described in other policy areas as well as an explanation for national-local differences (Breeman, Scholten, and Timmermans 2014).

On the other hand, there are scholars who have identified congruence in local responses fueled by a paradigm of exclusion (Mahnig 2004; Ambrosini 2013). Mahnig (2004) described how integration policies in Paris, Berlin, and Zurich have been reactive and ad hoc, with exclusionary political interventions triggered by fears that the presence and concentration of migrant communities could threaten social peace and public order. This becomes particularly visible in conflicts around religious buildings (Maussen 2009; Fourot 2010). Integration is put on the agenda only when it starts to be perceived as a political issue, concerning the whole 
urban community and not just ethnic minority groups. Local migrant organizations are not sufficiently able to mobilize their followers and to put their claims on the table to influence the political agenda and force a decision in their favor (Studlar and Layton-Henry 1990; Caponio 2005).

Even though there is disagreement on the characteristics of local integration policies, these strands of literature are alike in the way that they distinguish a local dimension of integration policies that differs significantly from integration policies on the national level. In terms of national-local relations, this "local dimension" thesis expects decentralized governance structures that allow local governments a large degree of policy discretion, while providing a national framework that promotes horizontal policy learning and provides only soft policy coordination. Cross-nationally, this thesis predicts congruencies between local-level migrant integration policies, in spite of potential national differences. Jørgensen (2012) argues that local congruencies can be reinforced by horizontal networks of knowledge exchange; these facilitate horizontal policy learning, also between local governments in different countries. Regardless of their national setting, the expectation is that the proximity of local governments to integration issues makes local policies similar in dealing with the presence of migrants.

A rival thesis claims that there will not only be differences between national and local integration policies but also between local policies because of differences in the local context. It assumes that local policies reflect the local problem situation, political setting, and specifically local policy legacies. For example, characteristics of a city's economy and migrant populations may matter to integration policies (Glick Schiller and Çağlar 2009). In terms of the policy setting, differences in local policy legacies but also in local politics matter (Mahnig and Wimmer 2000; Caponio and Borkert 2010). This contrasts with the local dimension thesis, which expects local governments to be congruent in their response to migrant populations in a specific direction.

Furthermore, in terms of the policy setting, Jørgensen (2012), and Glick Schiller and Çağlar (2009) have drawn attention to city branding and the role of local policy cultures in accounting for local integration policies. Take for example cities like Amsterdam or London, which have traditionally branded themselves as multicultural and cosmopolitan cities with significant tolerance to ethnic, cultural, and religious diversity. This contributes to the unique character of a city's integration policies. Thus, a second thesis expects there to be incongruences on the vertical dimension 
between national and local policies, as well as on the horizontal dimension between cities. In terms of governance structures, this thesis expects integration policies at different levels to be largely decoupled, possibly even involving policy contradictions or policy conflicts. Horizontal policy learning may apply in this model as well, but will be selective at best and will not be institutionalized.

A third thesis expects that local policies will simply reflect the national models of integration of the countries where the local governments are situated. Such "national models of integration" can be defined as nationally and historically rooted models of integration that are codified centrally and implemented in local-level policies. As such, these national models assume coherence of integration policies within nation-states (Brubaker 1992; Ireland 1994). This thesis expects top-down hierarchical governance structures to be in place that provide institutionalized forms of national-level policy coordination. The role of local governments is primarily perceived in terms of the elaboration and implementation of national policies.

Thus, this thesis predicts that there will be congruencies on the vertical dimension between national and local policies within specific countries. It is assumed that national models of integration are driven by strong issue linkages between migrant integration and other national issues, such as national identity, national security, or the welfare state. Therefore, this thesis predicts incongruences on the horizontal level between national migrant integration policies in different countries and also between city-level policies in different countries (Table 1).

\section{METHODOLOGY}

The empirical analysis involves an in-depth study of local and national policies in three cases: Malmö in Sweden, Rotterdam in the Netherlands, and Berlin in Germany. This involves a most different case study design based on three factors: First, the cities differ in size (roughly, Berlin 3,300,000, Rotterdam 600,000 and Malmö 300,000 inhabitants), gover-

TABLE 1

Overview OF Theses

\begin{tabular}{lll}
\hline \hline Thesis & National-local level & Cross country local level \\
\hline Local dimension thesis & Incongruence & Congruence \\
Localist thesis & Incongruence & Incongruence \\
National models thesis & Congruence & Incongruence \\
\hline
\end{tabular}


nance structures (Sweden and the Netherlands as [decentralized] unitary states and Germany as a federal state), and presumed typical national integration philosophies (Swedish multiculturalism, Dutch assimilationism and German welfare-state integration - Castles and Miller 2009 [1993]). All cities have experienced a large influx of immigrants over the past decennia and have developed policies to deal with integration issues.

By comparing national and local integration policies and analyzing institutional relations, the validity, and generalizability of the different theses can be assessed. We did not take into account the regional level of the federal state in Germany and the provinces in the Netherlands and Sweden. In the Netherlands, migrant integration is not dealt with on this level of government. In the case of Germany, Berlin is a city-state that has a direct relationship with the national government. In Sweden, the County Administrative Boards have gained responsibility in coordinating national and local integration policies. Their role in multilevel relations between Malmö and the national government will be addressed.

For each of the cases, national and local policy documents were analyzed, to reconstruct policy approaches and domains in the period 20052012. In addition, a review was made of secondary literature that focuses in particular on the policy process that led to these national and local policies. Finally, interviews were held with local policy makers (eight in Malmö, seven in Rotterdam and nine in Berlin). ${ }^{1}$ The interviews and consultation of secondary literature were conducted to reconstruct policy processes and multilevel interaction and to confirm whether our understanding of the local policies was correct and complete. Data collection took place under auspices of the UniteEurope project.

The three cases are strategically chosen for qualitatively evaluating the three theses by congruence analysis (Blatter and Haverland 2012). First of all, we analyzed (in)congruencies in integration policies in the various national and local cases. Similar to Alexander (2007), we used a typology of different policy domains at which integration policies can be

\footnotetext{
${ }^{1}$ In Berlin, nine interviews have been carried out with the integration commissioners of various districts, as well as with senior policy advisors from the integration commissioner's office of the Senate. In Malmö, eight interviews were carried out. Five with administrators working in the field of integration in the City of Malmö, two are working in leading positions for the state at the local level (employment service and the County Administrative Board) and one is a political secretary in the Commissioner's Unit at the City Office. In Rotterdam, seven interviews were conducted. The interviewees include administrators concerned with (civic) integration, current and former aldermen and their policy advisors.
} 
oriented (socio-cultural, socio-economic, legal-political) and normative premises about the inclusion of migrants. We distinguish multiculturalism, assimilationism, universalism, and differentialism as ideal typical approaches serving as a heuristic device to analyze our cases approaches to integration (Castles and Miller 2009 [1993]; Koopmans and Statham 2000). Domains and approaches often go together as the following paragraph will show.

Assimilationism can be defined as unidirectional integration of the immigrant in the host society while focusing primarily on the socio-cultural domain of migrant integration. Assimilationist policies encourage adaptation of migrants to dominant cultural norms, values, and behaviors. Multiculturalism also focuses primarily on the socio-cultural domain, but rather stresses cultural pluralism and encourages the emancipation of migrant groups while recognizing and institutionalizing specific group identities. Multiculturalist policies acknowledge the positive potential of immigrants for the city and are sensitive to the particular needs and problems of migrant groups. Universalist policies focus more on the socio-economic and legal-political domain of integration. Universalism is adverse to the institutionalization of majority or minority cultures. Universalist policies are "colorblind" and address the individual citizens' rights and obligations. Policy measures are often described as "mainstreaming." Finally, differentialism (also described as segregationism) institutionalizes group boundaries in society to such an extent that group identities and structures are preserved and groups live alongside each other rather than with each other. This applied to some extent to the guest-laborer regimes that were established in various European countries in the 1960s and 1970s, where apart from economic participation migrant groups were largely kept separated from society (Castles and Miller 2009 [1993]; Koopmans and Statham 2000).

Secondly, when assessing the analytical leverage of these three theses, we also look at institutional inter-government relations. The theses assume very different types of governance structures, which can involve formal or more ad hoc and informal ways of coordinating vertical (national-local) or horizontal (local-local) relations between government entities. The local dimension thesis assumes governance structures that leave significant "policy discretion" to the local policy practitioners and street-level bureaucrats. While little emphasis will be put on "vertical" national-local government relations, more effort will be put into horizontal policy networks. This may entail intra- or cross-national city-to-city networks of policy learning 
and exchanging, "best practices" or even sometimes ad hoc or informal exchanges. The localist thesis puts less emphasis on horizontal exchange of policy lessons and does to some extent emphasize vertical relations, but stresses independent policy development. Finally, the national models thesis also stresses the vertical dimension in particular, but then with a focus on top-down and hierarchical forms of policy coordination.

In the next paragraph, we will first compare the local integration policies of the three city cases in their historical and political context, assessing the local dimension thesis. Descriptive analysis of each of the local policies and the policy settings is followed by comparative analysis in terms of congruencies and horizontal relations. Subsequently, we will describe the respective national policies and their policy settings, finished by a congruence analysis of each case and the multilevel relations. This enables us to assess the localist and national models thesis.

\section{LOCAL INTEGRATION POLICIES AND HORIZONTAL RELATIONS BETWEEN BERLIN, MALMÖ, AND ROTTERDAM Berlin}

Since 1981 Berlin has known a Commissioner for Integration and Migration whose office is part of the Ministry for Work, Integration, and Women. Since the mid-2000s, two major integration policies have been developed: In 2005, the first Integrationskonzept, entitled "Encouraging diversity - Strengthening Cohesion," was formulated by the Senate and updated in 2007 (Der Beauftragte für Integration und Migration 2005, 2007). This policy can be characterized by a multiculturalist approach with universalist traits. "People with a migration background" are a specific policy target group. A State Advisory Board on Integration and Migration was initiated in 2003 including representatives from various immigrant groups. It participates in the city-state's agenda setting and policy development. The Integrationskonzept specifies eight issues of migrant integration. Two of the latter can be attributed to the socio-economic domain (labor market participation and education), one to the socio-cultural (international attractiveness and cultural diversity), three to the legal-political (interculturality of the public administration, participation in civil society, refugee integration), and one to the spatial domain of migrant integration (socio-spatial cohesion) (Der Beauftragte für Integration und Migration 2007, 8-90). 
In 2010, the Senate enacted the "Partizipations- und Integrationsgesetz" (PartIntG), a law mainly regulating the institutional setting in the policy field of migrant integration, as well as striving to remove obstacles for equal participation of migrants in all social areas such as institutional discrimination (Abgeordnetenhaus von Berlin 2010). PartIntG clearly concerns the legal-political domain of migrant integration. It aims to increase what is called the "interculturality of the city administration," by means such as increased employment of applicants with a migration background and training of staff. Furthermore, PartIntG focuses on the political participation of migrants, for example, by the appointment of commissioners, advisory boards, and committees on the district level, thereby reinforcing the city's multiculturalist institutional setting.

Berlin's districts (Bezirke) each have their own administration and are led by district councils that differ in terms of political composition. In a similar manner as the city-state, most districts have advisory boards and commissioners for integration. As one of our interviewees indicated, this institutional setting provides a challenge to policy coordination and coherence in Berlin. Districts focus mostly on the socio-economic domain of integration, revealing a accommodative approach to integration (diverse policy documents and interviews). However, socio-economic measures are often mentioned by interviewees as a condition for socio-cultural integration: "Education is most important. We do not have enough jobs for unskilled workers. (...) Migrants have to enter the regular job market. Where should they meet other people? The counter of the employment agency is not a good place for this. The workplace is an engine of integration." Policies on the district level are often the result of multi-stakeholder policy making. Rather than including migrants fully into the democratic process by providing them with voting rights as many demand for and as a more universalist approach would propose, policy making in Berlin in the realm of migrant integration is rather multiculturalist in the sense that migrants are given a separate voice, that is listened to by policy makers (Borkert and Bosswick 2007).

In sum, the main integration policies in Berlin indicate an emphasis on the legal-political domain of migrant integration, but do not neglect other domains. On the district level the socio-economic and socio-cultural domains are most prominent. A multiculturalist approach is most apparent in the policies, but interviewees noted struggles with universalist principles, for example, in case of the city's affirmative action in hiring staff. 


\section{Malmö}

The city of Malmö has a policy of integration mainstreaming. The 1999 action plan for integration understands integration as participation in society and mutual understanding between people with different backgrounds (City of Malmö 1999). Malmö envisions a city where all citizens are treated equally and where diversity is regarded as a benefit. Ethnic differences in labor market participation, spatial segregation, and school performance are considered to be current major integration issues. Malmö fears that the ethnic and socio-economic cleavages coincide and segregate the city. Most measures therefore target the social-economic domain of integration, for example, by labor market programs, language courses, and improving the quality of local schools.

The Commissioner for Employment and Adult Education is responsible for integration policies in Malmö. The Unit for Integration and Labour Market (INAR) develops and coordinates integration policies. Relevant municipal service providers are immigrant services (guidance and civic orientation for newly arrived humanitarian migrants); JobbMalmö (labor market measures); the Education Department (Swedish for Immigrants courses) and the ten city districts. Civil society organizations play just a marginal role (Scuzarello 2010). Sometimes they are a partner in specific projects or sometimes private companies are contracted for specific projects. For example, local football club FC Rosengard is funded for organizing projects focusing on education and employment for youth and adults.

Malmö aims to increase economic growth and to reduce ethnic segregation by implementing comprehensive welfare programs (GEFAS 1997-2000, Welfare for all 2004-2008 and the Commission for a socially sustainable Malmö 2010). As a senior civil servant at INAR puts is "What we used to call 'integration projects,' is no longer supported, unless there is a particular focus on work." Many measures also have a specific geographical focus. Neighborhood programs (City of Malmö 2011), health policies (City of Malmö 2010b), and infrastructure measures often target specific areas of the city where problems are the largest.

Few measures other than socio-economic integration measures get introduced and most are in theory aimed at the entire population and not specifically at migrant groups. An example is the action plan antidiscrimination (City of Malmö 2010a). Humanitarian migrants are the only group, that is targeted with specific measures. Legal-political and socio- 
economic issues are perceived to be most salient among this group as they are often struggling to enter the labor market. Therefore, specific policy measures aim to improve the introduction programs for humanitarian migrants. In general, Malmö has a universalist approach to migrant integration with a focus on the socio-economic domain of integration.

\section{Rotterdam}

Except for a short episode of assimilationist policies in the 1970s (interview with a senior policy maker), Rotterdam has long had an accommodative policy toward migrant integration that focused primarily on the socio-economic integration of migrants in the local housing- and labor market and in education (Rotterdam City Executive 1978; Governmental Board Rijnmond Area 1981; Rotterdam City Executive 1991). In the period 2002-2006, right wing party "Livable Rotterdam" gained a majority in the city council and has remained a powerful presence in local politics ever since. The party drew attention to popular resentment with diversity, in particular with Muslim immigrants. This enforced a more assimilationist approach to migrant integration (interviews with a policy maker and former politician). Rotterdam took new measures to promote dispersion of migrants across the city, to further inter-ethnic contact and to implement a local code of conduct (the so-called "Rotterdam Code").

Since 2006, Rotterdam has been mainstreaming its integration policies to various policy sectors. In fact, apart from the name of the coordinating administrative unit, "Immigration and Integration," Rotterdam no longer speaks of integration policies. The focus is not on integration of ethnic minorities but on participation of all citizens in society (interview with policy maker). Political shifts in 2006 marked a turn to policies with a more universalist character. Some policies still have particular attention for immigrants or address issues that mostly concern immigrants.

Policy measures - except for the organization of civic integration courses - are executed by NGOs that are subsidized by the municipality. Immigrant self-organizations and support organizations used to play a major role in agenda setting and execution of Rotterdam's integration policies. However, subsidies for migrant organizations have been cut over the past years. Currently, the subsidy infrastructure is limited to four areas of expertise: diversity, emancipation, non-formal education, and antidiscrimination (Rotterdam City Executive 2011a). Organizations had to reform in 
order to achieve more general participation goals and to yield measurable results (Rotterdam City Executive 2011a; interview with policy maker).

Rotterdam considers major integration issues to be minorities' labor market participation (primarily of women and youth), participation in non-paid voluntary work, language deficiencies, discrimination, delinquency (primarily of Antillean and Moroccan youth), acceptance of Dutch norms, and values such as tolerance toward homosexuality, ethnic segregation, and identification with Rotterdam's society (Rotterdam City Executive 2011a,b). Policies are clearly shaped in their local political setting and focus on the socio-cultural and socio-economic domain of integration with a universalist approach.

\section{Comparative Analysis of Local Policies and Relations}

The local dimension thesis would expect congruencies between local integration policies despite the existence of diverse national policy traditions. Our analysis has provided very little evidence for this thesis. There are significant differences in the target groups, domains, and approaches of local policies of the three cities, and they do not represent a singular accommodative or exclusionist policy frame. In Rotterdam, politicization at the local level triggered an episode of more assimilationist policies, followed by a current universalist approach. The policy now combines a socio-cultural and socio-economic focus. In Malmö, there is also a policy paradigm of universalism. However, the policies here are primarily addressing the socio-economic domain of integration. Berlin explicitly aims to streamline socio-economic and socio-cultural integration policies in the city districts by a legal-political policy frame on the city level. The policy can be characterized as multicultural with universalist traits.

In terms of horizontal exchange of knowledge and best practices, we did indeed found a number of international city networks, in which the three cities were involved. For instance, all three cities are part of the IntegratingCities network, although they did not always participate in projects from this network together. Malmö and Rotterdam are involved in the ImpleMentoring and Inti-cities project, while Berlin participated in the DIVE project. Only Malmö is involved in the CLIP project (Cities for Local Integration Policy 2014; IntegratingCities 2014). Our interviews show that this kind of knowledge exchange is appreciated, but current policies do not indicate significant policy learning. This suggests that the framing of local integration policies in these cities was driven primarily by 
specifically local circumstances and that horizontal policy learning was instrumental at best.

\section{NATIONAL INTEGRATION POLICIES AND MULTILEVEL DYNAMICS IN GERMANY, SWEDEN, AND THE NETHERLANDS}

\section{Germany}

National integration policies in Germany evolved bottom-up from the local level, with a strong involvement of (local) civil society (Heckmann 2003; Bommes 2010). Germany was for a long time reluctant to concede to the fact that it had become a country of immigration. A national policy that contained a clear recognition of Germany's status as an immigration country has evolved only recently. The Schröder government set up a multi-partisan committee of representatives of significant societal groups (churches, labor unions, employer associations, local public administrators, etc.), and researchers led by the opposition politician and former president of the Bundestag Rita Süßmuth to prepare a national immigration and integration policy in 2000. Thränhardt $(2009,165)$ interprets this consensus strategy in times of politicization of immigration and integration issues as a form of "staged corporatism." In the political context of the 9/11 attacks in the US and of national elections in Germany in 2002, an allparty agreement was reached on the first national law on immigration and migrant integration (Zuwanderungsgesetz) to come into effect in 2005 (Deutscher Bundestag 2005). This law for the first time regulates immigration to Germany, as well as obligatory civic integration of newly arrived migrants and therefore has a pivotal role in this policy field (Heckmann and Wiest 2013; Schneider and Scholten, forthcoming).

The Merkel government continued this strategy of consensus to draft the Nationaler Aktionsplan Integration: The commissioner for migration, refugees, and integration organized a series of summits on migrant integration (Integrationsgipfel). In these summits, again stakeholders including employer associations, labor unions, migrant communities, scientists, religious communities, etc. and government representatives of all levels of government were involved. This current national executive program defines eleven policy areas: (1) primary education; (2) secondary education, vocational training, and professional development; (3) labor 
market and working life; (4) minority hiring in the public sector; (5) health and care; (6) local integration; (7) language training; (8) sports; (9) civic engagement and integration; (10) media and integration; and (11) culture (Bundesregierung 2012, 19-197). Multi-stakeholder groups, each dealing with one of the areas, formulated strategic policy goals as well as operational aims, measures, instruments, responsibilities, time frames, and indicators for measuring progress.

Based on the process leading to Germany's national integration policy and the characteristics of this policy, we can define Germany's integration policy as multiculturalist with universalist traits according to our heuristic ideal types. On the one hand, the policy presupposes distinct cultural groups who shape the everyday reality of society and address multiple domains of migrant integration (five policy areas are part of socioeconomic, three socio-cultural, two legal-political, and one of the spatial domain). On the other hand, it does not stimulate the development of distinct groups, but rather pragmatically and stresses on welfare-state integration. Despite the assimilationist rhetoric in German politics, the policy itself is neither demanding migrants to undertake all integration efforts by themselves (as an assimilationist approach would require), nor does it refer to migrants as only one of many target groups of the policy (as a purely universalist approach would do).

\section{Sweden}

The Swedish government structure is a combination of a unitary state with strong local politico-administrative and fiscal capacities (Sellers and Lidström 2007). This relationship also characterizes Sweden's integration policies that evolved in a more centralized way. The national government decides on the general integration policy through laws and regulations, supervision, and fiscal incentives. At the same time, local government is given administrative and fiscal capacities to implement policies and also to decide on policies of their own. In Sweden's central government, the Ministry for Employment is responsible for integration, but the policy is supposed to permeate all government agencies.

On the national level, a new integration policy was introduced in December 1998 (Ministry of Interior 1997). It signaled a change away from a multiculturalist to a universalist policy focusing on individual rights and civic integration (Borevi 2012). The goal is equal rights, responsibilities, and opportunities for all regardless of ethnic or cultural 
background (Ministry of Finance 2008). This is to be achieved through general measures for the whole population supplemented by targeted support for migrants during their first years in Sweden. Despite the new policy direction, many multiculturalist policy programs were kept, such as the support for religious organizations and mother tongue language classes in schools (Dahlström 2004).

The introduction program for humanitarian migrants is the most important integration measure as it accounts for over 95 percent of the state integration budget (Ministry of Finance 2013). The goal is for participants to learn Swedish, find work, and support themselves financially, and learn about the rights and obligations of Swedish citizens. Since 1986, the responsibility to offer these services has been delegated to municipalities and financed by the state (Broomé, Rönnqvist, and Schölin 2007). In December 2010, the responsibility and coordination of the introduction programs were shifted back to the national government specifically the employment service. Reasons that were given for this are the poor results on labor market integration and too large differences between the programs of various municipalities (Ministry of Integration and Gender Equality 2010). However, the municipalities are still responsible for the implementation of services such as language courses and civic orientation for which they receive state funding. Most other integration measures on the national level have a focus on employment. One example is subsidized employment intended to strengthen migrants' competitiveness on the labor market.

\section{The Netherlands}

Migrant integration policies in the Netherlands were first developed in a centralized way, similar to the Swedish case. In the 1980s, the Ethnic Minorities Policy for which the Dutch case has become internationally (in)famous was developed and coordinated in a top-down way. This involved a unitary and centralized structure for policy coordination, with the Home Office at its center (Guiraudon 1997). In the 1990s, the integration policy gradually devolved to the local level. A direct connection was made between integration and other urban policies, and cities like Rotterdam and Amsterdam formulated their own policy perspectives on migrant integration. Since the early 2000s, policies on the national level have become more and more connected with migration and asylum policies and with abstract discussions on national values and how to protect 
these. This issue connection is also reflected in the development of (preand post-entry) civic integration programs for newcomers.

While the Netherlands has long been typified as multicultural, over the past decennium integration policies have taken an assimilationist turn (Scholten 2011). This was driven by a sharp politicization of migrant integration on the national level in the early 2000s. Past policies were denounced a failure and a new policy was installed ("Integration Policy New Style") that put more emphasis on the socio-cultural domain of integration and made a stronger connection between immigration and integration. The most recent policy memorandum was launched in 2011: "Integration, Cohesion, Citizenship" (Ministry of Interior 2011). A sense of shared citizenship and community of all Dutch citizens is formulated as a policy goal. The policy document has an assimilationist as well as universalist tone as it encourages citizen's responsibilities and self-sufficiency.

The current national integration policy consists of three principles. The first is that integration is not the responsibility of the government but that of immigrants themselves. The second principle is that "not one's background but one's potential is what counts" (Ministry of Interior 2011, 7). This implies that there are no targeted integration measures for ethnic minorities, but that there is a generic policy. The last principle is that generic policy measures are to facilitate every citizen's participation on the labor market, housing market, and in education. When the policy is insufficient for some groups, no specific instruments will be developed, but the general policy will be changed. The latter reflects a mainstreaming of migrant integration policies throughout various government sectors that was also found in the Swedish case.

\section{Comparative Analysis of Local and National Policies and Multilevel Relations}

We now turn to the localist thesis and the national models thesis that are more or less each other's opposites. The national models thesis claims that local integration policies will resemble the national policy frames because of top-down hierarchical governance structures. Cities will first and foremost have an executive role in integration policies. The localist thesis states that local policies will be shaped primarily by the specific local problem and policy context and are thus independent of national policies. 
While comparing Berlin's integration policies on the city and district level with those on the national level, we found both congruencies and incongruences. On all levels of governance in Germany, we found a similar approach to integration that can best be described in terms of our ideal type of multiculturalism, yet with important universalist traits. This becomes apparent in the process leading up to the policies, as well as in the content of the policies themselves. Integration policies are not only directed toward migrants, but also toward the majority society, which should be understood as a universalist trait. Nevertheless, migrants are perceived of as a diversity of groups who have different requirements and face various challenges. Migrant groups are identified as particular stakeholders who should not as regular citizens, but as representatives of a migrant population be included in the policy process. While we found a tendency to focus on socio-economic and socio-cultural areas of migrant integration on the national level, we found that the policies in Berlin particularly in the districts - have a broader focus, with an emphasis on the legal-political and socio-economic domains of integration. The policy levels are thus not fully congruent.

Institutional factors contribute to congruencies between the different levels of government. Berlins Integrationskonzept was developed almost half a decade before the Nationaler Aktionsplan Integration and was certainly perceived as a model for the latter. They have a similar format in terms of defining goals, measures, responsibilities, and indicators for success. The institutional and communicative setting of the Integrationsgipfel encouraged frame alignment among senior public administrators on different levels of government. This facilitated consensus among the different stakeholders in the integration policy field. The Länder and the umbrella organization of the German municipalities had to and did commit to the goals of the Nationaler Aktionsplan Integration along with the national government. The document constitutes a rare example of vertical multilevel policy making in Germany, or, as Heckmann and Wiest $(2013$, 8) put it "a coordinated commitment by political and civil society actors at all levels of government and civil society to initiate certain integration policies in their field of responsibility." Thus, the German case supports the national models thesis in the sense the both policies follow a similar approach ideologically as well as content wise. However, it is very clear that this is not due to top-down policy enforcement. Instead, we came across examples of bottom-up multilevel dynamics. 
In the case of Malmö and Sweden, formal and informal institutional arrangements have led to congruencies between the two policy levels. Both levels of government share the ideology and the goals of the integration policy, that is, based on a universalist philosophy with some multicultural features (support of the frame alignment is evident in all interviews). There is general agreement of the main principles of the integration policy in Sweden rather than any specific national policy effort. National-local interaction regarding integration policies has been governed through soft policy measures. In the mid-80s a system of negotiation was created, based on agreements between central government and the municipalities (cf. Qvist 2012). These agreements have, together with other organized professional networks, created common professional norms and practices that influence the local organization and content of introduction programs.

In 2001, the Swedish Integration Board initiated a more institutionalized collaboration to improve coordination of the introduction programs. The strategy was based on different voluntary agreements of policy coordination between actors at different administrative levels. After the closure of the Integration Board in 2007, this collaborative strategy is coordinated by the county administrative boards. These represent the state and serve as a link between the central government and municipalities. In the field of integration, they have the responsibility to coordinate, monitor, and develop integration measures for newly arrived migrants from a regional perspective. Local policies are organized in the Swedish Association of Local Authorities and Regions who safeguard the interests of Swedish local and regional authorities.

An example of national-local congruence is that when integration issues moved from the Ministry for Integration and Gender Equality to the Ministry of Employment at the government level in 2010, the city of Malmö decided to do the same and make integration issues a part of the policy area "labor market and adult education." Other domains of integration converge at the national and local level in their lack of policy measures. For example, there are no formal consultation bodies representing migrants in neither Malmö nor the central government and both levels of governance have reduced the financial support to minority organizations. Their voices should, according to the logic, be channeled through the same democratic process as those of the rest of the population. The focus on general policies, mainstreaming, and an avoidance of any policies that emphasizes ethnic or cultural difference is evident in both levels of gover- 
nance, which shows that the philosophy of integration is more universalist than multicultural.

A top-down approach does not fully explain national-local congruencies in Sweden, despite the more centralist government structure. The localist thesis is also partially supported. The precarious socioeconomic position of Malmö has led to an even stronger focus on socioeconomic issues than on the national level. The overall strategy has been to increase economic growth by city branding and large investments in infrastructure and to simultaneously counteract socio-ethnic segregation by general welfare measures. Incongruences are mostly found regarding the asylum regime. Malmö has repeatedly criticized the asylum reception policy that allows asylum seekers to live in own accommodations while their asylum application is processed. Overcrowding and ethnic segregation due to this policy have, according to the municipality, negative effects on integration.

In Rotterdam, many bottom-up multilevel dynamics have also been at play while the national models thesis is supported at first glance. During the last decade, national and local policies have converged toward a universalist approach to integration. Migrant integration is primarily framed in terms of socio-economic and socio-cultural participation and migrant groups are not addressed separately in policy measures. However, also incongruences exist between the national and local policies. In contrast to the issue connection with immigration and the focus on national identity in Dutch national integration policies, the local policies of Rotterdam have been much more concerned with concrete integration issues in spheres like education, housing, and labor.

Especially in earlier years, Rotterdam's political setting enforced divergent integration policies, giving support to the localist thesis as well. Our interviews and policy documents reveal many instances where the city of Rotterdam played an active role in national policy developments as well. Rotterdam did not simply fulfill a role as implementer of national policies, it has been a key policy entrepreneur in the multi-level governance setting of migrant integration, influencing national policies in a concerted effort to broaden the scope for local policies (see also Scholten 2013). Policies such as the Rotterdam Law were picked up nationally after an intensive policy lobby (Dutch Government 2005), later only to be implemented in Rotterdam. Also, over the past five years Rotterdam has become a key policy entrepreneur on the topic of inclusion of EU labor migrants, especially from Central and Eastern Europe. In this respect, it 
has exerted significant influence not just on national policies but on European policies as well. In 2008 arrangements of multi-level cooperation were formalized in a "Collaborative Integration-Agenda" between several municipalities and the central government (Ministry VROM 2008; Twynstra Gudde 2012). In 2012, this was continued as the "Collaborative Integral Approach" (Ministry of Interior 2012). This approach sets only the general contours of a policy to be implemented in different sectors and increasingly at the local level.

All in all, our analysis shows that the integration policies in Berlin, Malmö, and Rotterdam are to a large extent congruent with their respective national policy frames. However, an important finding from our analysis is that while the national models thesis seems to hold best, we also encountered many examples of bottom-up policy entrepreneurship. Multi-level governance interactions play a role in all cases and promote frame alignment between the national and local level.

\section{CONCLUSIONS}

Multi-level governance of integration issues and the question whether there is a distinctive local level of integration policies gained more attention over the past years. In this study, we have brought together three theses on the characteristics of local integration policies and we have qualitatively evaluated them with a comparative case-study of three city cases. We compared integration policies of Berlin, Malmö, and Rotterdam on the local level and we compared the local policies with their respective national policy contexts.

By conducting a congruence analysis, we aimed to go beyond evaluating the theses with a simple yes or no. We conclude that the local dimension thesis does not hold for Berlin, Malmö, or Rotterdam. Neither are the policies structurally more accommodative or exclusionist toward migrants than the national policies, nor do they resemble each other in that way. Also, there are indeed horizontal networks for policy learning between cities throughout Europe, yet the impact of horizontal policy learning on policy making appears to be limited.

Evidence supports both the national models thesis and localist thesis to a certain extent, but both explanations are not fully supported. Local integration policies resemble their national policies to a great extent, but not due to top-down hierarchical government structures. Rather, what we found are various forms of two-way multilevel interaction. Formal and 
informal institutional arrangements exist in which knowledge and practices are exchanged and frame alignment is fostered. We found many examples of bottom-up processes influencing national developments in accordance to the local policy philosophy. In line with the localist thesis, we found that local problem and political settings matter as well. However, political ideologies are not always followed up in concrete measures and local policies are not developed totally independent from the national policy frameworks. The congruency on the national-local axis is remarkable, and the multilevel interactions in all three cases reflect universalist traits.

Our analysis thus shows that there is not a single, distinct local dimension of integration policies, but that multilevel interactions promote mutual exchanges between local and national level policies. This speaks to the broader debate in the migration literature on national models of integration and the growing interest for city-level integration policies. Our study suggests that we should not treat these two levels, and perhaps also the European level, as too distinct from each other. Rather, we must focus attention much more to the complex forms of interaction that exist between different policy levels (vertical modes of interaction), as well as between different cities and countries (horizontal modes of interaction). This will help migration studies reach beyond reifying images of so-called national models of integration as well as beyond insulating the local dimension of integration policy making too much from the broader institutional context in which these local policies evolve.

Expanding this line of research involves further research in how these vertical and horizontal relations are configured under different circumstances. Several national-local comparisons show different levels of congruence under different institutional circumstances. For example, we know that the integration policies in Amsterdam differ from Rotterdam by reflecting the national policies to a lesser extent (Scholten 2013). In the German city of Halle/Saale, Glick Schiller and Çağlar (2009) found no evidence of a multiculturalist approach to migrant integration as there were no resources for migrant-specific assistance and ethnic-based organizations. By this, Halle/Saale does not adhere to the national integration policy paradigm. There is a need for further research on to what extent frame alignment between national and local policies also holds for different cities in the same national context, for instance, cities with different socio-economic backgrounds, different migration histories, and different political leadership. 


\section{REFERENCES}

Alexander, M.

2003 "Local Policies Toward Migrants as an Expression of Host-Stranger Relations: A Proposed Typology.” Journal of Ethnic and Migration Studies 29 (3):411-30.

2007 Cities and Labour Immigration. Comparing Policy Responses in Amsterdam, Paris, Rome and Tel Aviv. Aldershot: Ashgate.

Ambrosini, M.

2013 "We are Against Multi-Ethnic Society: Policies of Exclusion at the Urban Level in Italy." Ethnic and Racial Studies 36 (1):136-55.

Jørgensen, M. B.

2012 "The Diverging Logics of Integration Policy Making at National and City Level." International Migration Review 46 (1):244-78.

Blatter, J., and M. Haverland

2012 Designing Case Studies. Explanatory Approaches in Small N-Research. New York: Palgrave MacMillan.

Bommes, $\mathrm{M}$.

2010 "Migration Research in Germany: The Emergence of a Generalised Research Field." In National Paradigms of Migration Research, edited by M. Bommes and D. Thränhardt, 127-86. Osnabruck: V\& R Unipress.

Borevi, K.

2012 "Sweden: The Flagship of Multiculturalism." In Immigration Policy and the Scandinavian Welfare State 1945-2010, edited by G. Brochmann and A. Hagelund, 2596. New York: Palgrave Macmillan.

Borkert, M., and W. Bosswick

2007 "Migration Policy-Making in Germany. Between National Reluctance and Local Pragmatism?” IMISCOE Working paper 20. Amsterdam: IMISCOE.

Bousetta, H.

2001 "Immigration, Post-Immigration Politics and the Political Mobilisation of Ethnic Minorities. A Comparative Case-Study of Moroccans in Four European Cities." $\mathrm{PhD}$ diss., Catholic University Brussels.

Breeman, G., P. Scholten, and A. Timmermans

2014 "Analysing Local Policy Agendas: How Dutch Municipal Executive Coalitions Allocate Attention" Published online first on June 20, 2014. http://www.tandfonline. com/doi/abs/10.1080/03003930.2014.930024\#.U_xFpMW1beA.

Broomé, P., S. Rönnqvist, and T. Schölin

2007 "Vita Fläckar - Om Integrationspolitik, Ledning och Mångfald i Malmö Stad (White Spots - On Integration Policy, Management and Diversity in the City of Malmö)" Current Themes in IMER Research. Malmö: Malmö University.

Brubaker, R.

1992 Citizenship and Nationhood in France and Germany. Cambridge: Harvard University Press.

Caponio, T., and M. Borkert

2010 “Introduction." In The Local Dimension of Migration Policymaking, edited by T. Caponio and M. Borkert, 9-32. Amsterdam: Amsterdam University Press.

2005 "Policy Networks and Immigrants' Associations in Italy: The Cases of Milan, Bologna and Naples." Journal of Ethnic and Migration Studies 31 (5):931-50. 
Castles, S., and M. J. Miller

2009 [1993]. The Age of Migration. International Population Movements in the Modern World. New York: Palgrave McMillan.

Cities for Local Integration Policy

2014 CLIP Website. http://www.eurofound.europa.eu/areas/populationandsociety/clip.htm.

Dahlström, C.

2004 "Nästan Välkomna. Invandrarpolitikens Retorik och Praktik. (Almost Welcome. Rhethoric and Practice in Immigrant Policy)." Göteborg Studies in Politics 87. Gothenburg: Department of Political Science, Göteborgs Universitet.

Fourot, A.-C.

2010 "Managing Religious Puralism in Canadian Cities: Mosques in Montreal and Laval." In The Local Dimension of Migration Policymaking, edited by T. Caponio and M. Borkert, 135-60. Amsterdam: Amsterdam University Press.

Glick Schiller, N. and A. Çă̆lar

2009 "Towards a Comparative Theory of Locality in Migration Studies: Migrant Incorporation and City Scale." Journal of Ethnic and Migration Studies 35 (2):177-202.

Guiraudon, V.

1997 "Policy Change Behind Gilded Doors: Explaining the Evolution of Aliens' Rights in France, Germany and the Netherlands, 1974-1994." PhD diss., Harvard University.

Heckmann, F.

2003 "From Ethnic Nation to Universalistic Immigrant Integration: Germany." In The Integration of Immigrants in European Societies: National Differences and Trends of Convergence, edited by F. Heckmann and D. Schnapper, 45-78. Lucius: Bamberg. and D. Wiest

2013 DIAMINT - Country Report Germany. Bamberg: Europäisches forum für migrationsstudien.

IntegratingCities

2014 IntegratingCities Website. http://www.integratingcities.eu/.

Ireland, P.

1994 The Policy Challenge of Ethnic Diversity: Immigrant Policies in France and Switzerland. Cambridge: Harvard University Press.

Koopmans, R., and P. Statham

2000 Challenging Immigration and Ethnic Relations Politics. Oxford: Oxford University Press.

Mahnig, $\mathrm{H}$.

2004 "The Politics of Minority-Majority Relations: How Immigrant Policies Developed in Paris, Berlin and Zurich.” In Citizenship in European Cities. Immigrants, Local Politics and Integration Policies, edited by R. Penninx, K. Kraal, M. Martiniello, and S. Vertovec, 17-37. Farnham: Ashgate Publishing. and A. Wimmer

2000 "Country-Specific or Convergent? A Typology of Immigrant Policies in Western Europe." Journal for International Migration and Integration 1 (2):177-204.

Marques, M., and R. Santos

2004 "Top-Down and Bottom-Up Reconsidered: The Dynamics of Immigrant Participation in Local Civil Society." In Citizenship in European Cities. Immigrants, Local Politics and Integration Policies, edited by R. Penninx, K. Kraal, M. Martiniello, and S. Vertovec, 17-37. Farnham: Ashgate Publishing. 
Maussen, M.

2009 "Constructing Mosques. The Governance of Islam in France and the Netherlands." $\mathrm{PhD}$ diss., Amsterdam School for Social Science Research.

Moore, D.

2004 "Migrants as Mediators in a Comparative Perspective." In Citizenship in European Cities. Immigrants, Local Politics and Integration Policies, edited by R. Penninx, K. Kraal, M. Martiniello, and S. Vertovec, 17-37. Farnham: Ashgate Publishing. Penninx, R.

2009 "Decentralising Integration Policies. Managing Migration in Cities, Regions and Localities." Policy Network Paper November. London: Policy Network. K. Kraal, M. Martiniello, and S. Vertovec

2004 "Introduction: European Cities and Their new Residents." In Citizenship in European Cities. Immigrants, Local Politics and Integration Policies, edited by R. Penninx, K. Kraal, M. Martiniello and S. Vertovec, 17-37. Farnham: Ashgate Publishing.

Poppelaars, C., and P. Scholten

2008 "Two Worlds Apart. The Divergence of National and Local Immigrant Policies in the Netherlands." Administration \& Society 40 (4):335-57.

Qvist, M.

2012 "Styrning av Lokala Integrations Program: Institutioner, Nätverk och Professionella Normer Inom det Svenska Flyktingmottagandet.” PhD diss., Linköpings Universitet.

Scuzarello, S.

2010 "Caring Multiculturalism: Local Immigrant Policies and Narratives of Integration in Malmö, Birmingham and Bologna." PhD diss., Lunds Universitet.

Sellers, J., and A. Lidström

2007 "Decentralization, Local Government, and the Welfare State." Governance: An International Journal of Policy, Administration, and Institutions 20 (4):609-32.

Schneider, J., and P. Scholten

Forthcoming Consultative Committees and the Rethinking of Integration Policies in the Netherlands and Germany: The Blok Committee and the Süssmuth Committee

Scholten, P. Compared.

2011 Framing Immigrant Integration: Dutch Research-Policy Dialogues in Comparative Perspective. Amsterdam: Amsterdam University Press.

2013 "Agenda Dynamics and the Multi-Level Governance of Migrant Integration. The Case of Dutch Migrant Integration Policies." Policy Sciences 46:217-36.

Schrover, M., and F. Vermeulen

2005 "Immigrant Organisations." Journal of Ethnic and Migration Studies 31 (5):823-32.

Studlar, D. and Z. Layton-Henry

1990 "Nonwhite Minority Access to the Political Agenda in Britain." Policy Studies Review 9 (2):273-93.

Thränhardt, D.

2009 "Migrations- und Integrationspolitik: Vom Korporatismus zur Inszenierten Verstaatlichung." In Interessenvermittlung in Politikfeldern, edited by B. Rehder, T. von Winter, and U. Willems, 156-74. Wiesbaden: Verlag für Sozialwissenschaften.

Vermeulen, F., and R. Stotijn

2010 "Local Policies Concerning Unemployment Among Immigrant Youth in Amsterdam and in Berlin: Towards Strategic Replacement and Pragmatic Accommodation." In 
The Local Dimension of Migration Policymaking, edited by T. Caponio and M. Borkert, 109-34. Amsterdam: Amsterdam University Press.

\section{POLICY DOCUMENTS}

\section{Germany and Berlin}

Abgeordnetenhaus von Berlin

2010 "Gesetz zur Regelung von Partizipation und Integration in Berlin (Law for the Regulation and Integration in Berlin)."

Bundesregierung

2012 "Nationaler Aktionsplan Integration (National Action Plan for Integration)." Federal Republic of Germany.

Der Beauftragte für Integration und Migration

2005 "Vielfalt Fördern - Zusammenhalt Stärken. Das Integrationskonzept für Berlin. (Encouraging Diversity - Strengthening Cohesion).” Berliner Beiträge zur Integration und Migration.

Der Beauftragte für Integration und Migration

2007 "Vielfalt Fördern - Zusammenhalt Stärken. Das Integrationskonzept für Berlin. (Encouraging Diversity - Strengthening Cohesion).” Berliner Beiträge zur Integration und Migration.

Deutscher Bundestag

2005 "Gesetz zur Steuerung und Begrenzung der Zuwanderung und zur Regelung des Aufenthalts und der Integration von Unionsbürgern und Ausländern (Law on the Control and Limitation of Immigration and the Regulation of Residence and Integration of Citizens of European Member States and Foreigners)." Bundesrepublik Deutschland.

\section{Sweden and Malmö}

City of Malmö

1999 "Action Plan to Promote Integration in the City of Malmö."

City of Malmö

2011 "Nu Lyfter vi Malmö: Områdesprogram för ett Socialt Hållbart Malmö (Neighbourhood Program for a Socially Sustainable Malmö)."

City of Malmö

2010a "Action Plan Against Discrimination."

City of Malmö

2010b "Commission for a Socially Sustainable Malmö."

Ministry of Interior

1997 "Proposition 1997/98:16 Sverige, Framtiden och Mångfalden - Från Invandrarpolitik Till Integrationspolitik (Sweden, Future and Diversity - From Immigrant Policy to Integration Policy)."

Ministry of Integration and Gender Equality

2010 "New Policy for the Introduction of Newly Arrived Immigrants in Sweden."

Ministry of Finance

2008 "Proposition 2008/09:01 Budget 2009 (Budget Bill 2009)"

Ministry of Finance

2013 "Proposition 2013/14:01 Budget 2014 (Budget Bill 2014)." 


\section{The Netherlands and Rotterdam}

Governmental Board Rijnmond Area (Openbaar Lichaam Rijnmond)

1981 "Nota Culturele Minderheden in het Rijnmond Gebied. (Policy Note Cultural Minorities in the Rijnmond Area)."

Ministry VROM, Minister of Housing, Neighbourhoods and Integration

2008 "Datgene wat ons Bindt. Gemeenschappelijke Integratieagenda van Rijk en Gemeenten (Collaborative Integration Policy Agenda.)," 2nd and 3rd edition 2009 and 2010.

Ministry of Interior

2012 "Samen Leven Bindt Verschillen. Integratie in (Versnelde) Transition. Gemeenschappelijke Integrale Aanpak. (Integration in Transition. Collaborative Integral Approach)."

Ministry of Interior

2011 "Integratienota Integratie, Binding, Burgerschap (Integration Policy Note Integration, Cohesion, Citizenship).”

Rotterdam City Executive

1978 "Nota Migranten in Rotterdam (Policy Note Migrants in Rotterdam)."

Rotterdam City Executive

1991 "De Nieuwe Rotterdammers. (New Citizens of Rotterdam)."

Rotterdam City Executive

2011a "Burgerschapsbeleid Participatie: Kiezen Voor Talent. De Invulling van het Burgerschapsbeleid Voor de Jaren 2012 tot 2015 (Citizenship Policy Participation: Choosing Talent. Citizenship Policy for the Years 2012 to 2015)."

Rotterdam City Executive

2011b "Collegeprogramma 2010-2014. Werken aan Talent en Ondernemen. (City Executive Program 2010-2014).”

Twynstra Gudde

2012 "Rapport Eindevaluatie Gemeenschappelijke Integratieagenda. (Final Evaluation Collaborative Integration Policy Agenda)."

Dutch Government

2005 "Wet Bijzondere Maatregelen Grootstedelijke Problematiek (Law Special Measures for Urban Issues)." 


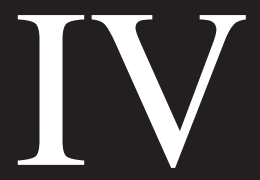





\section{A national turn of local integration policy: multi-level governance dynamics in Denmark and Sweden}

Henrik Emilsson

Correspondence:
henrik.emilsson@mah.se
Malmö Institute for Studies of
Migration, Diversity and Welfare
(MIM), Malmö University, Malmö,
Sweden
Sweden

\begin{abstract}
There is a growing interest in the research community in the local governance of migration and integration. Studies indicate a local turn in integration policies, with local governments becoming important integration policy actors. Unlike most research, this study of recent developments in the policies for migrant newcomers in Denmark and Sweden observes a national turn in local integration policy. Despite their different integration policies, the central governments of both countries have increased their control and influence at the local level and thereby made it more difficult for local governments to formulate their own integration policies. This study highlights the need to complement earlier research based on frame analysis with an analytical framework that takes central government steering and the uneven power relationship between the levels of government into account.
\end{abstract}

Keywords: Local integration policy; Multi-level governance; Integration policy; Sweden; Denmark; National integration models

\section{Analyzing local integration policy-the setting}

There is a growing interest in the research community in the local aspects of integration and migration (Alexander 2007; Caponio and Borkert 2010). The local dimension of integration policy is also acknowledged at the European level, where more efforts are being made to promote knowledge exchanges between cities, for example the CLIP project and the EuroCities network. Criticism of methodological nationalism (Wimmer and Glick-Schiller 2003) seems to have fuelled a desire to go beyond an analysis of integration policies at the national level. Instead of studying national models of integration, the focus has been on understanding whether and how national policies are implemented at the local level and whether municipalities are formulating policies of their own. Most of these studies indicate a local turn of integration policy and that local governments have increased their significance as integration policy actors (Alexander 2007; Penninx et al. 2004; Penninx 2009; Caponio and Borkert 2010; Schmidtke 2014). Many of the studies of local integration policies have a multi-level governance perspective. Their main focus is on the relations between national and local integration policies, especially the congruencies and incongruences between local and national policies and between local policies in different cities (Borkert and Bosswick 2007; Poppelaars and Scholten 2008; Bak Jørgensen 2012; Scholten 2013; Dekker et al. 2015).

(c) 2015 Emilsson et al. This is an Open Access article distributed under the terms of the Creative Commons Attribution License (http:// creativecommons.org/licenses/by/4.0), which permits unrestricted use, distribution, and reproduction in any medium, provided the original work is properly credited. 
While some studies find that national models of integration are still highly influential at the local level, and that there is a congruence between national and local integration policies (Dekker et al. 2015), most research indicates a growing incongruence between the national and local level (Bak Jørgensen 2012; Scholten 2013). There are two main explanations for these incongruences. The local pragmatism thesis argues that there is a specific local dimension of integration policies characterized by a greater tendency to accommodate ethnic diversity and solve integration problems in pragmatic ways (Caponio and Borkert 2010; Poppelaars and Scholten 2008; Bak Jørgensen 2012). The localist thesis argues that there are no national or local models of integration, but that local policies are uniquely shaped by the specific problem-, political- and policy settings in the different cities (Alexander 2007; Mahnig 2004). Both the local pragmatist thesis and the localist thesis suggest a disintegration of national integration models and point to the importance of studying integration policy beyond national frameworks.

The fieldwork and research undertaken for the EU-7 framework project, UniteEurope in Copenhagen and Malmö, ${ }^{1}$ made me question the growing consensus on the increased importance of the local level in integration policies. I therefore decided to look for a methodological and theoretical framework that would facilitate an analysis of the recent developments in Denmark and Sweden. The aim of this article is to add a new approach to the study of local integration policies by looking at the multi-level governance of integration policies through a power perspective lens. Power is operationalized by analysing the autonomy of local governments and their compliance with national policies. Contrary to most research, I argue that what we are witnessing is a national turn on local integration policy, where local integration policies and practices are increasingly governed by the state. Using case studies from Denmark and Sweden, I show that in recent years the governments of the two countries have increased their control and local influence and thereby limited the possibilities for local governments to formulate their own integration policies.

One important explanation as to why most researchers agree on a local turn of integration policy and that national models of integration are becoming weaker is that they look at the relationship between the local and national level using frame analysis (see for example Bak Jørgensen 2012; Scholten 2013). This makes them look at integration policy from a rhetorical perspective, i.e. how an actor defines the problems, diagnoses the causes, makes moral judgements and suggests remedies for integration (D'Angelo and Kuypers 2010). Official policy documents are studied with a view to unveiling the central organizing idea or ideology behind the policies. If local governments are found to adopt official integration policies that are ideologically different from those of the central government, the conclusion is that national models of integration are disintegrating. This divergence of local and national integration policy frames has been identified by Bak Jørgensen (2012) in the case of Denmark and by Scholten (2013) in the case of the Netherlands. With regard to Germany, Schmidtke (2014) finds that the growing divergence is a result of a conscious choice to decentralize public policy responsibilities from the federal to regional and local governments. These studies have contributed to the understanding that local governments can also be integration policymakers. At the same time, they risk giving the wrong impression of what is happening at the national and local level when it comes to integration policy. 
I see two main weaknesses with using policy frames to study the multi-level governance of integration. The first is that policy frames/integration ideologies may not mirror actual integration policies and measures. For example, Dahlström (2004) has found striking discrepancies in Sweden between integration rhetoric and integration practice. Although the national integration policy frames have changed several times since the adoption of the first immigrant policy in 1968 - from universalism to multiculturalism and back again - the practices and measures have not changed in any major way. A similar phenomenon can be found at the local level, where local integration policies often lack legitimacy and are assigned a subordinate role in the administration (Caponio 2010:179). The second weakness, and the most important for my argument, is that frame analysis often fails to address the power relationship between national and local governments. As I will show, national governments use steering instruments that to a large extent determine the municipalities' discretion when it comes to local integration policies. If the state decides which integration measures should be implemented at the local level it means that local authorities have little room for manoeuvre. Although I suggest that there is a national turn in local integration policies, it does not mean that local dimensions of integration policies do not exist, or that the scholars using frame analysis are wrong in their conclusions that there is a policy divergence between national and local levels of government. Integration policies that go against the national models can be formulated at local level, but may be limited in scope.

The aim of the article is to study whether there is a local or national turn in local integration policies and how this has come about. The cases studied are Denmark and Sweden: two countries with similar welfare states and local government structures (Sellers and Lindtsröm 2007) but with very different national integration policies (Brochmann and Hagelund 2012). The stipulation of a national turn is put to the test using these two cases. Denmark and Sweden are two of the most decentralized countries in the world (Sellers and Lindtsröm 2007) and their migration and integration policies have diverged tremendously over the years of study. If both countries are found to have experienced a national turn of local integration policy the study will have made a valuable contribution to research, especially as in many ways they represent least likely cases.

As will be shown, both national governments have increased their control and local influence and thereby limited the possibilities for local governments to formulate their own integration policies. The centralization of local integration policies has occurred in both cases, albeit in a different way and using different strategies. The increased interference of the national governments in local integration policies takes the form of laws and regulations that force local municipalities to implement certain integration measures by means of increased state funding for measures implemented at the local level and increased direct state involvement in the implementation of local integration policies. Last but not least, in Denmark, state legislation has had an increasing impact on the lives of individual migrants.

Even though this article only investigates the developments in Denmark and Sweden, there are signs of a broader European trend towards a national turn of local integration policy. Other countries have also centralized their integration policies. For example, Germany introduced a national integration policy in 2005 and state agencies are now responsible for integration programmes at the local level. In the last 15 years, many European countries have also introduced civic integration policies that have substantially increased the integration requirements for migrant newcomers (Wallace Goodman 2010). 
There is not enough space in this article to analyze and discuss how the multi-level relationship between central and local governments is played out in all the different dimensions of integration. In this article, the focus is on local integration policies for migrant newcomers, because this has been one of the most contested integration topics in recent years in both Denmark and Sweden. Newcomer integration is also a topic on which states and cities tend to diverge in perspective and approach (Gebhardt 2014:3). In the concluding section of the article I sketch a model that demonstrates how the theoretical framework used in this article can be utilized to examine the multi-level governance of integration in a more comprehensive way in future research.

\section{Framework for analyzing local integration policy and multi-level governance}

As indicated at the beginning of the article, most studies of multi-level governance and local integration policy use frame analysis and have focused on the narratives and philosophies of integration and how they differ at the local and national level. I argue that this method only captures one side of the multi-level relationship. In this article I use a method that captures the power relation between the national and local government levels, which in turn determines the discretion at local level when it comes to integration policy. The development of multi-level governance is often described as a result of three broad developmental trends: up, down and out (Pierre and Peters 2000), or as combining a vertical and horizontal dimension of multi-level governance (Hooghe and Marks 2003). In this article I am only interested in the relation between the state and the local level/municipalities. In the literature it has been noted that responsibility for certain policy areas has shifted downwards to the regional and local political levels (Hooghe and Marks 2001) and that governments have replaced traditional forms of governing with governance. The question is whether this is true for integration policies.

I analyze the multi-level governance of integration using a theoretical model inspired by Etzioni (1975), which was originally developed to make a comparative analysis of complex organizations. The model's main advantage is that it captures the power relations between those higher and lower in rank (ibid. p.5). The central concept in Etzioni's book is compliance, which he sees as a key element in all organizations. Compliance relations are asymmetric and vertical. It is about how subordinated actors behave in relation to another actor's power, and how those in power make other actors follow their directives. As Etzioni points out, a compliance relationship does not assume that the subordinates have no power, only that they have less (Etzioni 1975, p.4). Etzioni mainly uses his model to understand power relations between people within an organization, although his model has also been used to study how the state governs its authorities and local governments (Vedung 1991). The relationship we are interested in here is that between the state and local governments. They are part of a common organization, and while local governments have more or less power depending on their national settings, they are always subordinate to central government.

The superior actor, in this case national governments, uses power to ensure the compliance of other actors to carry out the directives and norms it supports. Etzioni describes three instruments of power: coercive, remunerative and normative (ibid, p.5). In the case of states and local governments, it is probably better to use the terms coercive, economic and normative. The instruments can also be seen as sticks, carrots and persuasion. The strength of Etzioni's model is that it captures the multiple ways in which a 
central government can exercise power on local governments that goes beyond a traditional understanding of decentralization and centralization of fiscal resources and formal responsibilities. Thus, it captures a steering that is associated with both governance and government (Kjær 2004). An alternative theoretical model that could have been used to analyze the central and local government relations is that created by Goldsmith (2002), although his central concept is control and does not take all of the economic and normative instruments of central government into account.

The methodology of the article is straightforward. In order to study the developments between the local and central governments I mapped all the major policy decisions relating to migrant newcomers according to the three instruments of power (see sections The Swedish case and The Danish case). In the main, secondary literature was used to identify the relevant government documents and legislation that would facilitate an indepth study of the decisions taken.

Coercive instruments can be the laws and regulations imposed by the state through decisions in parliament or, in some cases, decided by central governmental agencies. The municipalities are obliged to act in accordance with these. The relationship between central and local government is in this case authoritative. Reallocations of authority between territorial levels can also be made if the state changes the providers of public services at the different levels of government (Porter and Olsen 1976). Economic instruments often take the form of state funding or the withdrawal of state funding for targeted measures at the local level implemented by local governments or nongovernmental organizations. Normative instruments involve attempts or the discontinuation of attempts to influence local governments by conviction, persuasion or knowledge. Direct verbal counselling, education and outreach activities are included here. These instruments are not mutually exclusive, but can be combined to enforce compliance at the local level. For example, if the state wants to introduce language tuition for migrants at the local level it can use coercive means through laws and regulations, economic means by providing funding or try normative means to convince municipalities that this is the right thing to do. Alternatively, the state may decide to change its strategy on language tuition, withdraw funding and pass decisions about policy choices to the local level.

In the next part of the article I look at the recent development of integration policies in Sweden and Denmark using the theoretical multi-level governance model described above.

\section{Two faces of centralization of integration policies}

This chapter begins with a brief explanation of the Danish and Swedish government system in order to understand the formal relationships between the local and national level. This is followed by two sections on the development of local integration policies for migrant newcomers in Denmark and Sweden.

\section{Governmental structure in Sweden and Denmark}

Local governments in Sweden and Denmark balance between self-government and central control and between the autonomous and integrational model of local government (Kjellberg 1995). According to the autonomous model, local governments are a separate 
sphere of government with a primary function to secure democratic participation and the efficient provision of local services. In the integrational model, local governments are one part of the public sector and their main role is to implement national policies. These tensions are evident in the Swedish and Danish integration policies, where the ambitions of the unitary state governments meet powerful local governments (Sellers and Lindtsröm 2007).

Swedish municipalities are regulated by the Local Government Act of 1991. The Act specifies the responsibilities of the municipalities and provides outlines for local government. According to the law, municipalities are responsible for childcare and for preschool, primary and secondary schools, the social services, care for the elderly, support for people with disabilities, health and environmental issues, emergency services (not policing, which is the responsibility of the central government), urban planning and sanitation (waste, sewage). Labour market policy is a state responsibility, although at the beginning of the 1990s local authorities became increasingly important actors in labour market policy measures at the local level.

In Sweden the public sector is made up of three levels: national, regional and local. The system consists of a centralized national government and municipalities that are to some degree autonomous and have far-reaching powers of their own. The central government exercises power at all three levels, which leads to a relatively complex structure at the local level. There are also regional municipalities, which are mainly responsible for health care and transportation in the region. The municipalities therefore share both power and responsibility with national and regional institutions at the local level.

The principles for local self-government are stated in the constitution. Local and regional municipalities have the right to levy taxes and determine tax rates. The central government has the overall responsibility for determining how resources are to be distributed within the country and directs local activities by providing economic guidelines and establishing framework legislation. One of the goals of central government is to guarantee a minimum standard in relation to the various types of service provided by the municipalities (Gustafsson and Svensson 1999). Although the national government sometimes decides what municipalities should and must do, they nevertheless have something of a free rein. As we shall see, framework legislation and attempts to guarantee equal access to services for migrants have been important aspects of the development of integration policy in Sweden.

In Sweden there have been trends towards centralization and decentralization in the last decades. In some cases, the state has decentralized responsibilities from regional state administrations to regional governments. At the same time, the central government has passed several laws that restrict the power of local governments. According to Feltenius (2007), this development is explained by a renewed importance of the principle of equality in welfare provisions.

In Denmark there has been a clearer trend towards decentralization. The major municipal reform of 2007 transferred power to the municipalities. Responsibility for primary education, the social services, care for the elderly, physical planning and child care was retained and in some cases expanded. Municipalities were also given increased responsibility for education, the social services, rehabilitation (outside hospitals) and health promotion. The reform was completed in 2009 when labour market services were decentralized to the municipalities (Blom-Hansen 2012). Today the municipalities 
alone provide services to the public sector in Denmark (Vrangbk 2010). These changes also meant a potential increased autonomy in the field of integration policy.

The municipalities and the regions are allowed to take responsibility for areas as long as they do not clash with the responsibilities of the national government or another municipality/region. Most local government functions are carried out with full discretion, apart from some social security benefits (old age pensions in particular) where central government covers part of the costs. The recent reform has strengthened the level of municipal autonomy and made the country even more decentralized than before. Municipalities are entrusted with more fiscal, political and administrative autonomy than in any other country (Ivanyna and Shah 2012). At the same time as the municipalities' powers were enhanced the regions became less important, with fewer responsibilities and no power to tax their citizens. There is no system of subordination between the regions and the municipalities because they have different tasks and responsibilities. Therefore, the public sector in Denmark only has two levels of governing institutions.

\section{The Swedish case}

Sweden has had a comprehensive immigrant policy in place since 1975 (Bill 1975:26), when a multiculturalist policy was agreed by parliament. Even though many changes in content and terminology have been made since then, the basic framework still applies, which is that migrants should have the same living standards as the native population. Migrants with residence permits therefore have the same rights as Swedish citizens and are covered by the welfare state. Several policies have been introduced: mother-tongue instruction in schools for migrant children, voting rights for foreign citizens in local elections and subsidies for immigrant associations. After 1985 there was a move away from multicultural policy for cultural and economic reasons (Schierup and Ålund 2011; Geddes 2003; Södergran 2000) and 'immigrant and minority policy' was renamed 'immigrant policy' as a result. Following the reorientation in the 1980s the state remained the guarantor of immigrants' social and political rights but not of their minority cultural rights. As the number of humanitarian migrants gradually increased, responsibility for integration was transferred from the Employment Service to the municipalities (Prop. 1983/84:125). This shift of responsibility was part of a larger reform aimed at decentralizing integration policies to the municipalities. At the same time, the most important part of Swedish integration policy, namely the introduction programme for humanitarian migrants, was introduced. This is the topic in focus for the remainder of the analysis.

Since decentralization in 1985 , the central government has gradually increased its efforts to influence local integration policies for migrant newcomers (see Table 1 for a summary). One reason for the decentralization of the introduction programmes was that the state wanted to introduce individually designed introduction programmes that also took the different local conditions into consideration (Sarstrand Marekovic 2012). Municipalities were supposed to offer services such as language training, civic orientation and labour market activities and the state would provide the funding. In many municipalities the migrants' social needs were prioritized (Soininen 1992). The local introduction programmes were often planned and implemented by social workers in line with the Social Services Act. After some time the state reacted to the "care" focus of the programmes and insisted on a stronger focus on labour market integration. 
Table 1 Policies for newly arrived migrants-Sweden

\begin{tabular}{|c|c|c|c|}
\hline Year & Content & Instrument & Political intention \\
\hline $\begin{array}{l}1985 \\
\text { (Bill 1983/84:125) }\end{array}$ & $\begin{array}{l}\text { Responsibility for } \\
\text { introduction programmes } \\
\text { is transferred to } \\
\text { municipalities. }\end{array}$ & $\begin{array}{l}\text { Economic compensation } \\
\text { from the state to } \\
\text { municipalities. }\end{array}$ & $\begin{array}{l}\text { Adaptation of introduction } \\
\text { programmes to local } \\
\text { conditions. }\end{array}$ \\
\hline $\begin{array}{l}1991 \\
\text { (Bill 1989/90:105 and } \\
\text { Ordinance 1990:927) }\end{array}$ & $\begin{array}{l}\text { New system of } \\
\text { reimbursement to } \\
\text { municipalities for refugee } \\
\text { reception. Expansion of } \\
\text { the target group. }\end{array}$ & $\begin{array}{l}\text { Increased economic } \\
\text { incentives for municipalities. }\end{array}$ & $\begin{array}{l}\text { In collaboration with the } \\
\text { Employment Service give } \\
\text { local governments the } \\
\text { freedom to take active } \\
\text { measures to enable migrants } \\
\text { to become self-sufficient. }\end{array}$ \\
\hline 1992 (Bill 1992:1068) & $\begin{array}{l}\text { New introductory benefits } \\
\text { for refugees and other } \\
\text { foreigners. }\end{array}$ & $\begin{array}{l}\text { Increased economic } \\
\text { incentives for participants in } \\
\text { introduction programmes. }\end{array}$ & $\begin{array}{l}\text { Municipalities are given the } \\
\text { chance to use non-means } \\
\text { tested economic support to } \\
\text { participants in an introduction } \\
\text { programme. }\end{array}$ \\
\hline $\begin{array}{l}1998 \\
\text { (Bill 1997/98:16) }\end{array}$ & $\begin{array}{l}\text { New integration policy and } \\
\text { establishment of the } \\
\text { Integration Board. }\end{array}$ & $\begin{array}{l}\text { Increased normative } \\
\text { instruments for } \\
\text { implementation of } \\
\text { introduction programmes. }\end{array}$ & $\begin{array}{l}\text { The new agency is to help } \\
\text { municipalities to improve } \\
\text { support for new immigrants. }\end{array}$ \\
\hline 2001 & $\begin{array}{l}\text { Central, regional and local } \\
\text { agreements. }\end{array}$ & $\begin{array}{l}\text { Increased normative } \\
\text { instruments. }\end{array}$ & $\begin{array}{l}\text { Strategy to improve } \\
\text { collaboration and improve } \\
\text { coordination of introduction } \\
\text { programmes. }\end{array}$ \\
\hline $\begin{array}{l}2010 \\
\text { (Bill 2009/10:188) }\end{array}$ & $\begin{array}{l}\text { National Bonus for } \\
\text { language acquisition }\end{array}$ & $\begin{array}{l}\text { Increased economic } \\
\text { incentives for participants in } \\
\text { language tuition. }\end{array}$ & $\begin{array}{l}\text { Encourage new immigrants } \\
\text { to learn Swedish faster. }\end{array}$ \\
\hline $\begin{array}{l}2010 \\
\text { (Bill 2009/10:60) }\end{array}$ & $\begin{array}{l}\text { Responsibility for } \\
\text { introduction programmes } \\
\text { is transferred to the state. }\end{array}$ & $\begin{array}{l}\text { Coercive instruments } \\
\text { towards municipalities. } \\
\text { Increased economic } \\
\text { incentives for participants in } \\
\text { introduction programmes } \\
\text { and private actors. }\end{array}$ & $\begin{array}{l}\text { Speed up new migrants' } \\
\text { transfer into work. }\end{array}$ \\
\hline $\begin{array}{l}2014 \\
\text { (Bill 2012/13:188) }\end{array}$ & $\begin{array}{l}\text { Expansion of the target } \\
\text { group. }\end{array}$ & $\begin{array}{l}\text { Economic compensation } \\
\text { from the state to } \\
\text { municipalities }\end{array}$ & $\begin{array}{l}\text { Give more family-reunification } \\
\text { migrants right to an } \\
\text { introduction programme. }\end{array}$ \\
\hline
\end{tabular}

In 1991 the state decided on a new system of reimbursement to municipalities for refugee reception (Bill 1989/90:105 and Ordinance 1990:927). The purpose of the changes was to increase the incentives for municipalities to speed up the labour market integration. Previously, the state had compensated the municipalities' costs for social assistance. Now, municipalities were given a lump sum compensation for each person. This meant that local governments could keep the state money if the newcomers became self-sufficient at a faster rate than the 2 years covered by state funding. At this time the only coercive regulatory framework for the receipt of state funding was that an introduction plan had to be drawn up for each individual. One year later, in 1992, another economic incentive was introduced (Bill 1992:1068) which allowed municipalities to give non-means tested economic support to participants in an introduction programme and thereby increase their economic incentives to find employment.

The 1997 integration policy (Bill 1997/98:16) emphasized individual rights and mainstreaming, but did little to change existing integration measures. The regulatory framework for the local introduction programmes was also retained. In order to encourage municipalities to adopt more efficient introduction programmes with a stronger focus 
on employment, the state now turned to normative steering measures (Qvist 2012). A new state agency, the Swedish Integration Board, was set up. One of its main tasks was to stimulate and help municipalities to develop better and more efficient introduction programmes. The idea at that time was to design an individual introduction with a focus on work that, as far as possible, mimicked working life with activities amounting to a standard working week of 40 hours. The initial strategy of the agency was to provide local governments with knowledge, highlight good examples and write follow-up reports. When this strategy was seen as insufficient to influence policy change, the Swedish Integration Board initiated a strategy for the collaboration and coordination of integration programmes. It tried to increase policy coordination by means of different types of agreements between involved stakeholders at the national, regional and local level. This strategy was successful and produced local and regional agreements on work-first policy. However, according to Qvist (2012), this did not really lead to corresponding changes in the organization and structure of the local programmes.

Despite these efforts the central government was not happy about the efficiency of the programmes. The Social Democrat Government therefore appointed a Commission of Inquiry to suggest improvements. The proposals (SOU 2003:75) presented in 2003 would have meant a certain centralization of the introduction programmes, but the government failed to reach agreement with its coalition partners and the reform was abandoned. After the 2006 elections, and with a new centre-right government in place, the Swedish Integration Board was laid down. As the economic and normative steering instruments that had been tried had not yielded results, the government now introduced coercive methods. With the 2010 reform (Bill 2009/10:60) the state took over responsibility for the introduction programmes from the municipalities. According to the government, the old programmes had too little focus on labour market activities and resulted in slow labour market integration. Giving the Employment Service overall responsibility supposed to strengthen the work-first principle. The government also believed that the differences between how municipalities organized the programmes were too great and felt that centralization would guarantee a better implementation of state policy. The government also launched an introduction benefit for participants in the programme; an individual state allowance that replaced the old municipal social benefits. Despite the reform the need for local coordination remained great. Today, municipalities are still responsible for Swedish for Immigrants (SFI) and civic orientation courses, for which they receive state funding. A new private actor, an introduction guide, was also introduced to help migrants find employment, which further added to the need for coordination. The reform meant increased state involvement in three ways: the responsibility and administration for the introduction programmes moved from the municipalities to the state, state funding for the programme increased and the content of the programme became regulated by law.

The introduction reform has contributed to the greater centralization of integration policy for migrant newcomers in Sweden, although is not the only example of this. The state, which in Sweden is responsible for labour market policy, has introduced subsidized employment directed at migrant newcomers. The state budget for the local introduction programmes has sky-rocketed from about five billion SEK a year in 2006-2011 to 13 billion in 2014, and is expected to reach 25 billion in 2017. This is due to a rising number of humanitarian migrants in combination with increased spending per person. In addition, the 
target group for the introduction programmes expanded in January 2014 (Bill 2012/ 13:188). Family members of humanitarian migrants arriving in Sweden within a 6 years period, instead of 2 years, are now eligible for an introduction programme. Other state centralization efforts affecting the local level are a new law that forces municipalities to accept the settlement of unaccompanied minors, increased rights for undocumented migrants and state funding for local anti-discrimination measures.

\section{The Danish case}

Danish immigrant policy was progressively developed in the 1970 s by reforms in different policy areas. The main principle was equal rights in the welfare state with a few targeted measures, such as language training for migrant newcomers and mother-tongue instruction in schools (Vad Jönsson and Petersen 2012). When refugees began to arrive in larger numbers in the 1980s the government gave the NGO Danish Refugee Council responsibility for humanitarian migrant newcomers. Introduction activities were mainly carried out by the Danish Refugee Council, which was authorized to grant social benefits to participants. In 1986 Denmark introduced an 18-month long integration programme for humanitarian migrants. This programme included language training and civic orientation, but no labour market activities to speak of. After this period responsibility was handed over to the municipalities.

Just as in Sweden, in the last decade the Danish central government has decided on policies and legislation that have increased its influence on integration measures at the local level. This has not only had profound consequences for municipalities, but also for individual migrants (see Table 2 for a summary). The process started in 1994 when the Integration Action Plan made the municipalities responsible for language training for all migrant newcomers.

The 1998 Integration Act (Act no. 474 of 1 July 1998) made the municipalities responsible for carrying out the integration policy objectives (Jensen et al. 2010), primarily the introduction programme that was now expanded to include all non-EEA migrants. The aim was to improve the management and coordination of the integration programmes by assembling all the separate elements under the same political authority. The Act also stated labour market integration as an explicit goal for the first time. Municipalities are thus obliged to offer 3-year introduction programmes in which language training is the key pillar. Also, since 1999 it is up to the state to decide where humanitarian migrants should settle by assigning local and regional quotas (Nielsen and Jensen 2006). In other words, the municipalities are responsible for the introduction programmes and their tasks are clearly stated in the Act. Vad Jönsson and Petersen (2012) describe the policy change as a public centralistic welfare state solution. Djuve and Kavli (2007) categorize the introduction regime as a detailed law regulation. The cost of benefits and services are reimbursed by the state. The reimbursement system is quite complicated and different procedures have been used to encourage municipalities to implement efficient programmes. Since 2007 economic compensation to municipalities has consisted of three parts, one of which depends on the results of language training and labour market entry.

When several steps were taken to restrict the migration of non-EU citizens to the country the number of humanitarian and family migrants fell, while the number of other migrant categories rose. As a response to this, the Danish Government decided in 2010 to 
Table 2 Policies for newly arrived migrants_Denmark

\begin{tabular}{|c|c|c|c|}
\hline Year & Content & Instrument & Intention \\
\hline $\begin{array}{l}1994 \text { Integration } \\
\text { action plan }\end{array}$ & $\begin{array}{l}\text { Responsibility for language } \\
\text { training transferred to } \\
\text { municipalities }\end{array}$ & & \\
\hline $\begin{array}{l}1999 \text { (Act no. } 474 \\
\text { of } 1 \text { July 1998) }\end{array}$ & $\begin{array}{l}\text { Responsibility for } \\
\text { introduction programmes is } \\
\text { transferred to municipalities. }\end{array}$ & $\begin{array}{l}\text { Economic and coercive } \\
\text { instruments were introduced } \\
\text { directed at both municipalities } \\
\text { and participants in } \\
\text { introduction programmes. }\end{array}$ & $\begin{array}{l}\text { Make newly-arrived refugees } \\
\text { and immigrants active } \\
\text { participants, self-supporting } \\
\text { and with an understanding } \\
\text { of Danish fundamental } \\
\text { values and norms. }\end{array}$ \\
\hline $\begin{array}{l}2002 \text { (Act no. } 364 \\
\text { and no. } 365 \text { of } 6 \\
\text { June 2002) }\end{array}$ & $\begin{array}{l}\text { Integration requirements } \\
\text { were introduced for } \\
\text { obtaining permanent } \\
\text { residence permits. }\end{array}$ & $\begin{array}{l}\text { Economic and coercive } \\
\text { instruments directed at } \\
\text { participants in introduction } \\
\text { programmes. }\end{array}$ & $\begin{array}{l}\text { Migrants have a duty to } \\
\text { participate actively in the } \\
\text { different programme } \\
\text { elements. }\end{array}$ \\
\hline $\begin{array}{l}2006 \text { (Act no. } 243 \\
\text { of } 27 \text { March 2006) }\end{array}$ & $\begin{array}{l}\text { Migrants must sign an } \\
\text { integration contract. }\end{array}$ & $\begin{array}{l}\text { Normative instruments } \\
\text { directed at participants in } \\
\text { introduction programmes. }\end{array}$ & $\begin{array}{l}\text { Making Danish values more } \\
\text { visible. }\end{array}$ \\
\hline $\begin{array}{l}2007 \text { (Act no. } 379 \\
\text { of } 25 \text { April 2007) }\end{array}$ & $\begin{array}{l}\text { Immigration test for family } \\
\text { migrants is introduced }\end{array}$ & $\begin{array}{l}\text { Coercive instruments directed } \\
\text { at family migrants }\end{array}$ & $\begin{array}{l}\text { Foreigners are to receive } \\
\text { clear signals about what is } \\
\text { expected of them in } \\
\text { Denmark. }\end{array}$ \\
\hline $\begin{array}{l}2010 \text { (Act no. } 571 \\
\text { of } 31 \text { May 2010) }\end{array}$ & $\begin{array}{l}\text { The Integration Act was } \\
\text { extended to include labour } \\
\text { migrants and their families } \\
\text { plus EU migrants. }\end{array}$ & $\begin{array}{l}\text { Coercive instrument directed } \\
\text { at municipalities. }\end{array}$ & $\begin{array}{l}\text { Adjust the Act to a changed } \\
\text { migration pattern. }\end{array}$ \\
\hline $\begin{array}{l}2010 \text { (Act no. } 572 \\
\text { of } 31 \text { May 2010). }\end{array}$ & $\begin{array}{l}\text { New point based system } \\
\text { making it harder to obtain } \\
\text { permanent residence permit. }\end{array}$ & $\begin{array}{l}\text { Coercive instruments directed } \\
\text { at participants in introduction } \\
\text { programmes. }\end{array}$ & $\begin{array}{l}\text { Favour well-integrated while } \\
\text { making it harder for "less } \\
\text { integrated" migrants. }\end{array}$ \\
\hline
\end{tabular}

include other migrant categories in the Integration Act (Ersbøll and Gravesen 2010). For the municipalities this means that they now are obliged by law to offer a larger number of migrants an introduction course.

Due to the fact that coercive instruments were introduced at an earlier stage in Denmark to ensure compliance at the local level, normative instruments have not been used as extensively as in Sweden. The main normative instrument has been the benchmarking system for measuring municipalities' success in the labour market integration of migrant newcomers set up in 2002 (Liebig 2007) to compare the diffusion of effective integration measures between municipalities.

Compared to Sweden, the Danish state authorities are not involved in the implementation of the introduction programmes. However, municipalities must offer integration services to a broader target group, for which they receive state funding. We can thereby conclude that over time the state has increased its use of coercive and economic instruments to ensure compliance with national policies, which in turn has reduced the possibilities for municipalities to independently decide on integration policies for migrant newcomers.

The other aspect of the centralization of Danish integration policy is how the national integration policies affects individual migrant newcomers. This perspective of the debate on the local turn has been neglected. Most European countries have introduced some kind of forced integration in their migration and integration legislation, where migrants have to show a willingness and capacity to integrate in order to stay in the country and have equal rights (Wallace Goodman 2010). This type of legislation prevents municipalities from developing an independent local integration policy. In the Danish case, all the 
municipalities can do is administer the rules and procedures and advise migrant newcomers on the best way forward.

Besides the 1998 Integration Act (Act no. 474 of 1 July 1998) meaning less discretion for municipalities, it also signalled the start of one of the most restrictive and controlling integration regimes in Europe (see for example Mouritsen et al. 2009 and Ersbøll and Gravesen 2010). The Act introduced various integration requirements for obtaining a permanent residence permit. Now humanitarian migrants had to show 'a will to integrate' by participation in a 3-year integration programme. At the same time, the government introduced significantly lower welfare payments to humanitarian migrants (the so-called 'introduction benefit). Its official rationale was to increase the incentive to provide for oneself, although the lower benefit was also designed to prevent individuals from seeking asylum in Denmark in the first instance (Mouritsen et al. 2009). When a centre-right government took office with support from the Danish People's Party in autumn 2001, the path towards the restriction of immigration and the introduction of integration requirements was vigorously pursued. The requirements for obtaining a permanent residence permit and citizenship became tighter. Danish language tests and employment requirements were also introduced in order to qualify for permanent residence, family reunification and naturalization. The right to family reunification was also removed for everyone below the age 25 .

More legislation on integration requirements followed in 2006 and 2007 with the introduction of an integration contract and integration examination. These changes meant that the stakes for obtaining a permanent residence permit were raised. The required language level for permanent residence was increased to D2E, comparable to the European level B1. The applicant is also required to have been in ordinary full-time employment for at least 2 years and 6 months over the past 7 years. The latest major integration related policy changes were made in 2010. A pre-immigration test for foreigners applying for family reunification was introduced with a view to strengthening the individual foreigner's possibilities for a successful and rapid integration into Danish society. Applicants have to take the test in Denmark and are denied residence if they fail.

The integration legislation is based on the idea that 'permanent residence is reserved for foreigners who integrate', that 'results count' and that 'citizenship must be earned' (Ersbøll and Gravesen 2010). For the individual migrant, the integration process means a one-way compliance with the standards set by the state. Migrants therefore have to jump through several legal hoops and prove that they are economically independent and culturally integrated in order to become a Danish citizen (Howard 2009, Bak Jørgensen 2012).

To sum up, at the local level municipalities and individual migrants are increasingly governed by the central government. In 1999 the central government passed detailed legislation indicating the kind of introduction services a municipality had to offer nonEEA migrant newcomers. In 2010 the provisions were extended to all migrants. Also, municipalities have no say where humanitarian migrants are settled. For individual migrants, the coercive measures of the state are even more profound.

\section{Concluding discussion}

This article uses Denmark's and Sweden's policies for migrant newcomers as case studies to examine whether or not there has been a local or national turn in local integration policy. The analysis shows that today central governments have more influence 
and control over local integration policies for migrant newcomers than ever before. The developments can be seen as centralization, but could also be seen as a transition from steering through softer instruments (governance) to more traditional command and control instruments (government).

Since the early 1990s, the Danish and Swedish national governments have made considerable efforts to influence local integration policies for migrant newcomers in what is for them regarded as a desired direction. This has been a struggle, since both countries have some of the most decentralized government structures in the industrialized world. Normative, economic and coercive instruments have been used to make local governments comply with the ambitions of the national governments. In Denmark, the world's first integration law was passed in 1999 that provided municipalities with detailed instructions as to kind of introduction programmes they had to implement. Even though the government structure in Denmark was decentralized further in the beginning of the 2000s, local governments have very little autonomy in the integration policies of migrant newcomers. Their task is to implement what is laid down in the national laws. This also includes a large part of the administration compelling individual migrants to comply with the national integration requirements.

In Sweden the central government has been more hesitant about using coercive instruments to make local governments comply with national ambitions. Until 2010 the municipalities were able to decide for themselves what kind of introduction programmes they wanted to develop. The national government tried to steer the programmes towards a more work-line principle by using normative and economic instruments. After disappointing results, the national government decided to take over responsibility by putting the Employment Service in charge of the introduction programmes. In this respect the national government not only stripped the municipality of a large part of its autonomy, but also took control of the implementation procedure.

When Copenhagen, the capital of Denmark, proclaims that it will become the most inclusive city in Europe by 2015, that integration is a two-way process and that diversity is strength (Copenhagen 2011), it is easy to think that the Danish national model for integration is losing its influence and power. After all, the ambitions of Copenhagen are very different from the assimilation policy of the central government. But local integration policies matter little when central governments use coercive instruments to ensure compliance with national integration policies. A city like Copenhagen may want to break out of the policy frame set by the central government, but when it comes to policies for migrant newcomers, all they can do is decide more about less. The city still has to implement a never ending list of integration measures and administer the integration requirements directed at migrants that are laid down in the Integration Act and other state legislation.

The Copenhagen example shows that it is important to complement the research on local integration policy using frame analysis with research that also looks at the power relations between central and local governments and central governments' use of different instruments of compliance. This article has examined one area of integration policy, namely that directed at migrant newcomers. While most studies of multi-level governance and integration policy have found that local governments are increasing in importance, I have shown that when it comes to migrant newcomers, local integration policy is increasingly governed by national governments. In both the Danish and Swedish cases there has 
been a centralization of authority and disempowerment at the sub-national level. In Sweden, the national government ended up using coercive instruments and took over responsibility for the entire policy area. Municipalities are now subordinate to the state in the development of local introduction programmes. Denmark uses the Integration Act as a coercive instrument to make sure that local governments and migrant newcomers comply with the wishes of the Danish national government.

The findings suggest that national models of integration are still strong and have grown stronger in recent times. Whether this is true in other countries is an open question, as is whether other dimensions and areas of integration have developed in a similar way. In order to improve the knowledge on this topic I suggest a typology for future research that combines Alexander's (2007) typology of local migration policies with the Etzioni (1975) framework to analyze the power relations and compliance described in this article. In this way, the multi-level dynamics of local integration policy could be explored more fully.

In Table 3, three different instruments for compliance are listed on the vertical axis, as described in the theoretical framework. The horizontal axis includes the four dimensions of integration policy (Biezeveld and Entzinger 2003; Alexander 2007): socio-economic, sociocultural, legal-political and spatial (see also Freeman 2004; Samers 2010). The socio-economic dimension captures a broad category of policy areas, such as the labour market, education, housing, healthcare, social security and policing. The socio-cultural dimension captures the more subjective and interactive dimension of migrant integration. This dimension involves policies referring to processes of migrant acculturation. The legal-political dimension primarily captures the civic and political incorporation of migrants into society. The legal part of this refers to access to citizenship, anti-discrimination legislation and legal provisions that are specific to migrant groups. The spatial dimension basically separates out the indicators related to 'housing' from the socio-economic dimension and puts them together in a separate dimension. The spatial dimension refers to the housing position of migrants, as well as the spatial concentration or dispersion of migrants and symbolic spatial uses.

The different boxes in the table show examples of possible state involvement in local integration policy categorized by the instruments of compliance and the dimensions of integration. This article is situated in the socio-economic dimension and analyzes the multi-level relations between the state and municipalities over time in Denmark and Sweden. For a fuller picture of the multi-level dynamics of integration policy, other integration dimensions should also be studied to determine whether we really are experiencing a national or local turn of local integration policy.

Table 3 Typology of state-municipal relations in local integration policy, by compliance instruments and dimensions of integration

\begin{tabular}{lllll}
\hline & Socio-economic & Legal-political & Socio-cultural & Spatial \\
\hline Coercive & $\begin{array}{l}\text { Integration Act on introduction } \\
\text { programmes. }\end{array}$ & $\begin{array}{l}\text { Citizenship } \\
\text { legislation. }\end{array}$ & $\begin{array}{l}\text { Regulations of mother- } \\
\text { tongue } \\
\text { classes in schools. }\end{array}$ & $\begin{array}{l}\text { Regulations of } \\
\text { tax-reductions in } \\
\text { disadvantaged } \\
\text { neighbourhoods. }\end{array}$ \\
$\begin{array}{llll}\text { Funding for introduction } \\
\text { programmes. }\end{array}$ & $\begin{array}{l}\text { Funding for local } \\
\text { anti-discrimination } \\
\text { centres. }\end{array}$ & $\begin{array}{l}\text { Funding for civic } \\
\text { orientation education }\end{array}$ & $\begin{array}{l}\text { Funding for anti- } \\
\text { segregation } \\
\text { programmes. }\end{array}$ \\
$\begin{array}{llll}\text { State knowledge-sharing of } \\
\text { good examples of labour mar- } \\
\text { ket activities }\end{array}$ & $\begin{array}{l}\text { State advertisement } \\
\text { for local elections. }\end{array}$ & $\begin{array}{l}\text { State programmes for } \\
\text { religious tolerance in } \\
\text { schools. }\end{array}$ & $\begin{array}{l}\text { Voluntary } \\
\text { agreements on } \\
\text { refugee reception. }\end{array}$ \\
\hline
\end{tabular}




\section{Endnote}

${ }^{1}$ Some of the research is published in Dekker et al. (2015).

\section{Competing interests}

The author declare that he has no competing interests.

Received: 3 July 2015 Accepted: 3 July 2015

Published online: 12 August 2015

\section{References}

Alexander, M (2007). Cities and Labour Immigration: Comparing Policy Responses in Amsterdam Paris Rome and Tel Aviv. Aldershot: Ashgate Publishing.

Bak Jørgensen, M. (2012). The Diverging Logics of Integration Policy Making at National and City Level. International Migration Review, 46(1), 244-278.

Biezeveld, R, \& Entzinger, H. (2003). Benchmarking in Immigrant Integration. Rotterdam: Report for the European Commission. Blom-Hansen, J. (2012). Local Government in Denmark and the 2007 Municipal Reform. In A Moisio (Ed.), Rethinking local government: Essays on municipal reform. Helsinki: Vatt Publications.

Borkert, M, \& Bosswick, W (2007). Migration Policy-making in Germany. Between National Reluctance and Local Pragmatism?, IMISCOE Working article 20. Amsterdam: IMISCOE.

Brochmann, G, \& Hagelund, A. (2012). Immigration policy and the Scandinavian welfare state 1945-2010. London: Palgrave Macmillan.

Caponio, T, \& Borkert, M. (2010). The Local Dimension of Migration Policymaking. Amsterdam: Amsterdam University Press. Copenhagen (2011). Engage in CPH Citizenship + Inclusion, Copenhagen's integration policy 2011-2014. The City of Copenhagen: Employment and Integration Administration.

Dahlström, C. (2004). Nästan välkomna. Invandrarpolitikens retorik och praktik. (Almost Welcome. Rhetoric and Practice in Immigrant Policy). Göteborg Studies in Politics 87. Gäteborgs Universitet.

D’Angelo, P, \& Kuypers, JA. (2010). Doing News Framing Analysis. New York: Routledge.

Dekker, R, Emilsson, H, Krieger, B, \& Scholten, PWA (2015). A Local Dimension of Integration Policies? A Comparative Study of Berlin, Malmö and Rotterdam, International Migration Review. doi:10.1111/imre.12133.

Djuve, AB, \& Kavli, HC. (2007). Integrering i Danmark, Sverige og Norge: Felles utfordringer - like løsninger? [Integration in Denmark, Sweden and Norway: Mutual Challenges - same solutions?], Tema Nord 2007:575. Copenhagen: Nordisk Ministerråd.

Ersbøll, E, \& Gravesen, LK. (2010). Country Report Denmark, The INTEC project: Integration and Naturalisation tests: the new way to European Citizenship. Centre for Migration Law: Radboud University Nijmegen.

Etzioni, A (1975). A comparative analysis of complex organizations: on power, involvement, and their correlates. New York: The Free Press.

Feltenius, D. (2007). Relations Between Central and Local Government in Sweden During the 1990s: Mixed Patterns of Centralization and Decentralization. Regional \& Federal Studies, 17(4), 457-474.

Freeman, GP. (2004). Immigrant incorporation in Western democracies. International Migration Review, 38(3), 945-969.

Gebhardt, D. (2014). Building Inclusive Cities: Challenges in the Multilevel Governance of Immigrant Integration in Europe. DC, Migration Policy Institute: Washington.

Geddes, A. (2003). The Politics of Migration and Immigration in Europe. London: SAGE Publications.

Goldsmith, M. (2002). Central Control over Local Government - A Western European Comparison. Local Government Studies, 28(3), 91-112.

Gustafsson, L, \& Svensson, A (1999). Public Sector Reform in Sweden. Malmö: Liber AB.

Hooghe, L, \& Marks, G. (2001). Multi-level Governance and European Integration. Rowman \& Littlefield cop: Lanham, MD.

Hooghe, L, \& Marks, G. (2003). Unravelling the Central State, but How? Types of Multi-level Governance. American Political Science Review, $97,233-243$

Howard, MM (2009). The politics of citizenship in Europe. New York: Cambridge University Press.

Ivanyna, M, \& Shah, A. (2012). Policy Research Working Article 6138. The World: Bank. How Close Is Your Government to Its People? Worldwide Indicators on Localization and Decentralization.

Jensen, TG, Schmidt, G, Tørslev, MK, Vitus, K, \& Weibel, K (2010). Analysis of Integration Policies and Public State-Endorsed Institutions at National and Regional Levels in Denmark, Working article produced within the TOLERANCE project, EU-TOLERACE: The Danish National Centre for Social Research.

Kjær, AM. (2004). Governance. Cambridge: Polity Press.

Kjellberg, F. (1995). The Changing Values of Local Government. The ANNALS of the American Academy of Political and Social Science, 540(1), 40-50.

Liebig, T (2007). Labour market integration of immigrants in Denmark. OECD Social, employment and migration working articles No.50, Paris: OECD.

Mahnig, H. (2004). The Politics of Minority-Majority Relations: How Immigrant Policies Developed in Paris, Berlin and Zurich. In R Penninx, K Kraal, M Martiniello, \& S Vertovec (Eds.), Citizenship in European Cities (pp. 17-37). Immigrants, Local Politics and Integration Policies, Farnham: Ashgate Publishing.

Mouritsen, P, Lex, S, Lindekilde, L, \& Olsen, V. (2009). Immigration, integration and the politics of cultural diversity in Denmark: Political discourses and legal, political and educational challenges: Integrated country report. Department of political science: University of Aarhus.

Nielsen, CP, \& Jensen, KB. (2006). Integrationslovens betydning for flygtninges bosätning [The impact of the Integration Act on the settlement of refugees]. Köpenhamn: AKF-förlag.

Penninx, R. (2009). Decentralising Integration Policies. Managing Migration in Cities, Regions and Localities, Policy Network Article November. London: Policy Network

Penninx, R, Kraal, K, Martiniello, M, \& Vertovec, S. (2004). Citizenship in European Cities. Immigrants, Local Politics and Integration Policies. Farnham: Ashgate Publishing. 
Pierre, J, \& Peters, BG. (2000). Governance, Politics and the State. New York: St. Martin's Press.

Poppelaars, C, \& Scholten, P. (2008). Two Worlds Apart. The Divergence of National and Local Immigrant Policies in the Netherlands. Administration \& Society, 40(4), 335-357.

Porter, D. O. \& Olsen, E. A. (1976). Some critical issues in government centralization and decentralization. Public Administration Review, 36(1), 72-84

Qvist, M (2012). Styrning av lokala integrationsprogram: Institutioner, nätverk och professionella normer inom det svenska flyktingmottagandet [Governing Local Integration Programmes: Institutions, Networks and Professional Norms in Swedish Refugee Reception]. Linköping: Linköpings Universitet.

Samers, M. (2010). Migration. London: Routledge.

Sarstrand Marekovic, AM (2012). Kommunalt mottagande av invandrare och flyktingar - 40 år av utmaningar och erfarenheter [Local integration of immigrants and refugees - 40 years of challenges and experiences]. Socialmedicinsk tidskrift 2/2012,

Schierup, C, \& Ålund, A. (2011). The end of Swedish exceptionalism? Citizenship, neoliberalism and the politics of exclusion. Race and Class, 53(1), 45-64.

Schmidtke, O. (2014). Beyond National Models? Governing migration and integration at the regional and local levels in Canada and Germany. Comparative Migration Studies, 2(1), 77-99.

Scholten, PWA (2013). The multi-level governance of migrant integration: a multi-level governance perspective on Dutch migrant integration policies, In AO Korkut (Ed.), The Politics of Migration in Europe. The role of language, discourse and political parties. New York: Palgrave.

Sellers, JM, \& Lindtsröm, A. (2007). Decentralization, Local Government, and the Welfare State. Governance: An International Journal of Policy, Administration, and Institutions, 20(4), 609-632.

Soininen, M. (1992). Det kommunala flyktingmottagandet: genomförande och organisation (The municipal refugee reception: implementation and organization). Stockholm: Centrum för invandringsforskning (CEIFO).

Södergran, L. (2000). Svensk Invandrar- och Integrationspolitik: En fråga om jämlikhet, demokrati och mänskliga rättigheter [Swedish Immigration and Integration Policy: A question of equality, democracy and human rights]. Umeå: Umeå University.

Vad Jönsson, H, \& Petersen, K (2012). Denmark: A National Welfare State Meets the World. In G Brochmann \& A Hagelund (Eds), Immigration Policy and the Scandinavian Welfare State. Hampshire: Palgrave Macmillan

Vedung, E. (1991). Utvärdering i politik och förvaltning [Evaluations in politics and administrations]. Lund: Studentlitteratur. Vrangbk, K. (2010). Structural Reform in Denmark, 2007-09: Central Reform Processes in a Decentralised Environment. Local Government Studies, 36(2), 205-221.

Wallace Goodman, S. (2010). Integration Requirements for Integration's Sake? Identifying, Categorising and Comparing Civic Integration Policies. Journal of Ethnic and Migration Studies, 36(5), 753-772.

Wimmer, A, \& Glick-Schiller, N. (2003). Methodological nationalism, the social sciences, and the study of migration: An essay in historical epistemology. International Migration Review, 37(3), 576-610.

\section{Submit your manuscript to a SpringerOpen ${ }^{\circ}$ journal and benefit from:}

- Convenient online submission

- Rigorous peer review

- Immediate publication on acceptance

- Open access: articles freely available online

- High visibility within the field

- Retaining the copyright to your article

Submit your next manuscript at $\downarrow$ springeropen.com 
Dissertation series in

\section{Migration, Urbanisation and Societal Change}

Faculty of Culture and Society

Malmö University

1. Henrik Emilsson, Paper Planes: Labour Migration, Integration Policy and the State, 2016 


This dissertation collects four peer-reviewed articles that are published in academic journals. Two of the articles are about the multi-level governance of integration polices, and two study the effects of labour migration policies.

The two topics are tied together by an introduction where a common theme of the articles is discussed - the role of the state. Based on the results of the four articles, it is argued that the relevance of the state as a unit of analysis is still strong and impossible to ignore if one wants to understand the patterns of migration and the conditions which migrant newcomers face in their countries of residence.

When the Swedish labour migration policy was changed, and the veto of the unions and the state (the Employment Service) was abolished, it enabled social networks and market forces to play out more freely, which led to an increase in labour migration. The Swedish 2008 labour migration policy was designed to solve labour shortages. However, the effect of the new law was mainly the creation of new opportunities for migrants to get work permits and visas to Sweden in order to apply for asylum or work in low-skilled jobs in sectors without labour shortages. Thus, state policies do matter, even if not always in the way in which policymakers intend them to. The state has also tightened its grip on local integration policies in both Denmark and Sweden, despite very different overall policies. Where Denmark's civic integration policies have formed a tighter relationship between the state and the individual, the Swedish way has been to centralise and standardise integration services and reduce local policy autonomy.

ISBN 978-9I-7IO4-730-4 (print)

ISBN 978-9I-7IO4-73 I-I (pdf) 